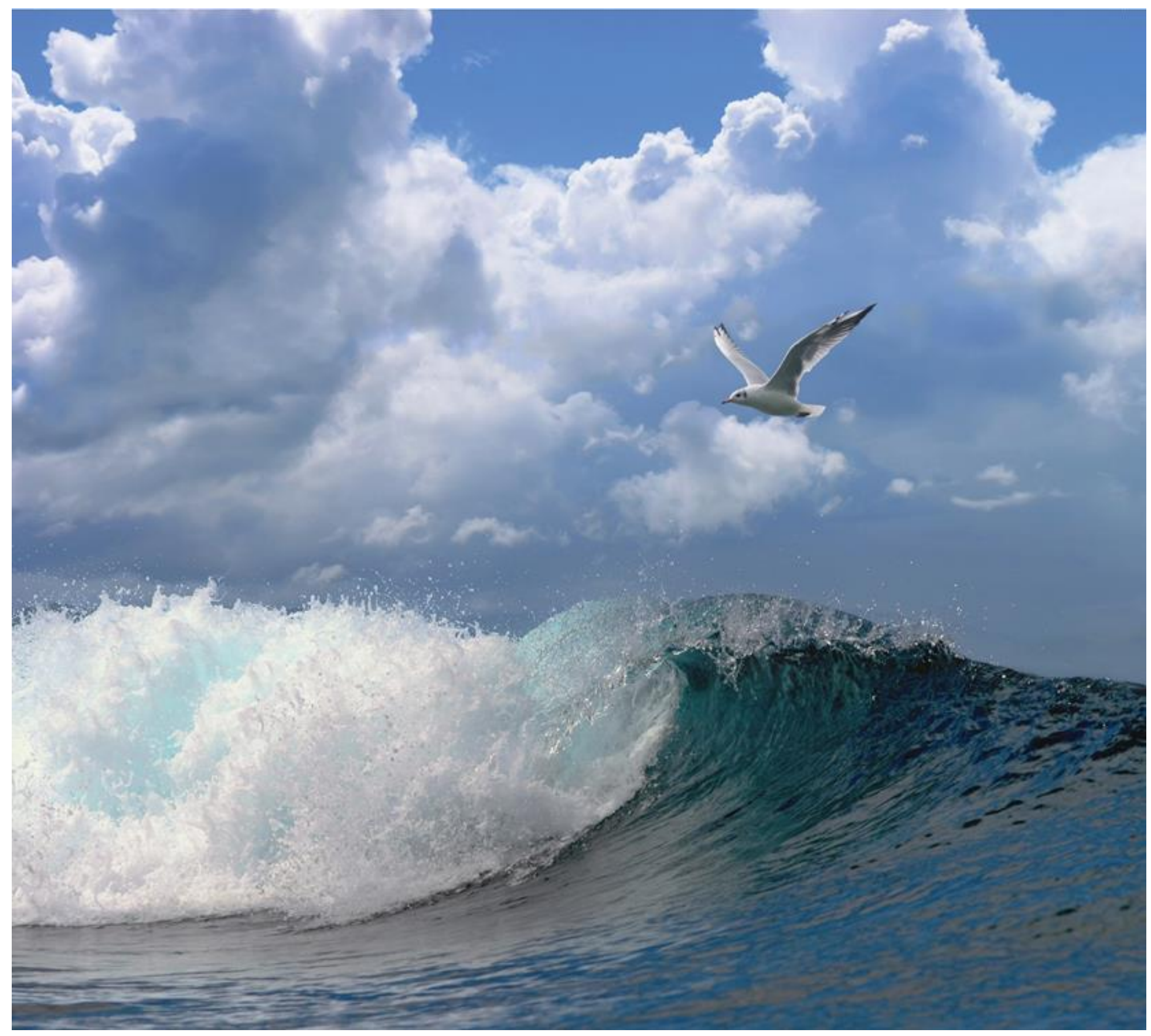

Electronic monitoring of incidental bycatch of harbour porpoise (Phocoena phocoena) in the Dutch bottom set gillnet fishery (September 2013 to March 2017) 


\section{Electronic monitoring of incidental bycatch of harbour porpoise (Phocoena phocoena) in the Dutch bottom set gillnet fishery (September 2013 to March 2017)}

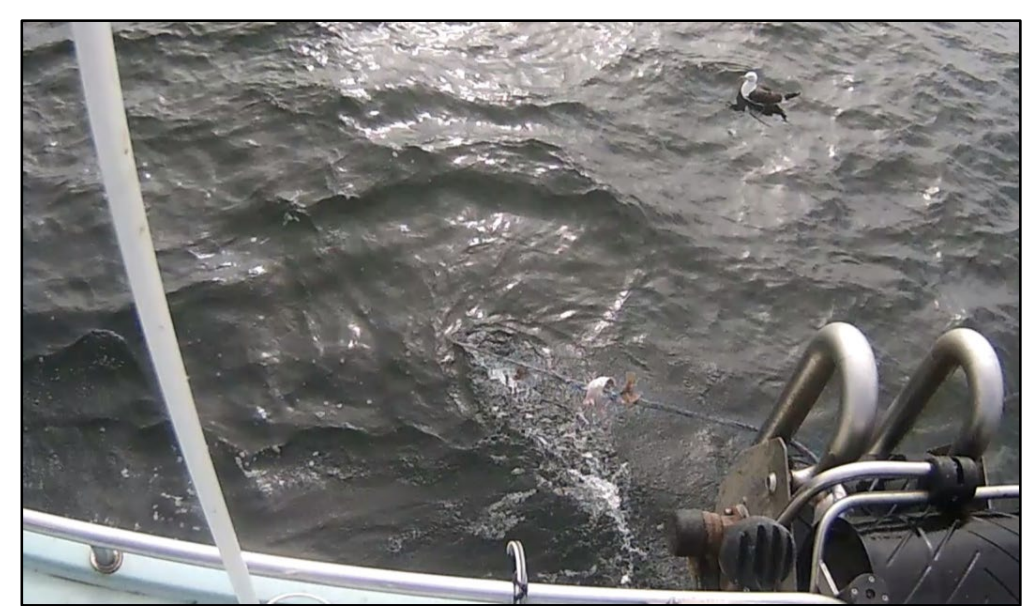

Author(s): Meike Scheidat, Bram Couperus, Marije Siemensma ${ }^{1}$

This research project was carried out by Wageningen Marine Research at the request of and with funding from the Ministry of Agriculture, Nature and Food Quality (project no. BO-11-011.04-019).

${ }^{1}$ Marine Science \& Communication (MS\&C), Driebergen 
Keywords: harbour porpoise, North Sea, bycatch, gillnet fishery

Client: $\quad$ Ministerie van Landbouw, Natuur en Voedselkwaliteit

Attn.: Dhr.K. Verbogt

Postbus 20401

2500 EK, Den Haag

This report can be downloaded for free from https://doi.org/10.18174/466450

Wageningen Marine Research provides no printed copies of reports

Wageningen Marine Research is ISO 9001:2015 certified.

\section{(C) Wageningen Marine Research}

Wageningen Marine Research, an institute Wageningen Marine Research accepts no liability for consequential damage, nor within the legal entity Stichting for damage resulting from applications of the results of work or other data Wageningen Research (a foundation under obtained from Wageningen Marine Research. Client indemnifies Wageningen Dutch private law) represented by Dr. Marine Research from claims of third parties in connection with this application. M.C.Th. Scholten, Managing Director All rights reserved. No part of this publication may be reproduced and / or

KvK nr. 09098104, published, photocopied or used in any other way without the written permission WMR BTW nr. NL 8113.83.696.B16.

Code BIC/SWIFT address: RABONL2U IBAN code: NL 73 RABO 0373599285 


\section{Contents}

\section{Contents}

$\begin{array}{ll}\text { Contents } & 3\end{array}$

$\begin{array}{lr}\text { Executive Summary } & 5\end{array}$

Samenvatting onderzoek "Onbedoelde Bijvangst in Beeld" 6

$\begin{array}{llr}1 & \text { Introduction } & 8\end{array}$

$2 \quad$ Materials and Methods $\quad 10$

2.1 Project organisation $\quad 10$

$\begin{array}{lll}2.2 & \text { Participating fishing vessels } & 11\end{array}$

2.3 Net types monitored 11

$\begin{array}{lll}2.4 & \text { Installation of Remote Electronic Monitoring (REM) systems } & 14\end{array}$

$\begin{array}{ll}2.5 & \text { Bycatch registration } \\ 2.6 & 15\end{array}$

$\begin{array}{lll}2.6 & \text { Data analyses } & 15\end{array}$

2.6.1 Electronic monitoring data 15

2.6.2 Bycatch calculation 16

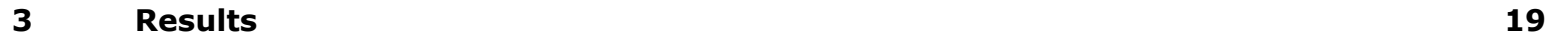

3.1 Monitoring effort $\quad 19$

3.1.1 Participation and installation of vessels 19

3.1.2 Monitoring coverage $\quad 20$

3.1.3 Fishing vessel length $\quad 21$

$\begin{array}{ll}3.1 .4 & \text { Fishing effort per net type }\end{array}$

3.1.5 Spatial coverage sample fishery $\quad 23$

3.2 Bycaught harbour porpoises $\quad 25$

3.2.1 Overview of registered porpoises in nets $\quad 25$

3.2.2 Positions of bycaught porpoises $\quad 26$

$\begin{array}{lll}3.3 & \text { Fishing effort } & 27\end{array}$

$\begin{array}{ll}3.4 & \text { Correction factors } \\ \end{array}$

$\begin{array}{lll}3.4 .1 & \text { Video quality } & 28\end{array}$

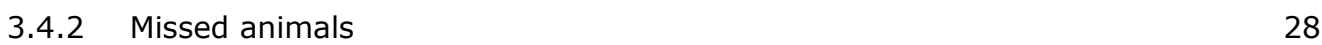

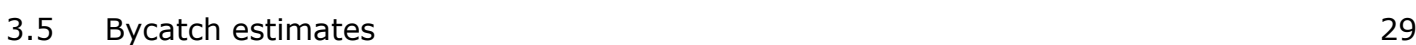

$\begin{array}{ll}3.5 .1 & \text { calculation of bycatch rates }\end{array}$

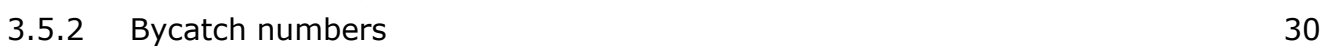

$\begin{array}{lll}3.6 & \text { Population effects } & 33\end{array}$

4 Discussion $\quad 35$

$\begin{array}{lll}4.1 & \text { Methodological considerations } & 35\end{array}$

4.1.1 The sampled fleet $\quad 35$

4.1.2 Extrapolation of effort data $\quad 36$

$\begin{array}{lll}4.2 & \text { Harbour porpoise bycatch } & 37\end{array}$

4.2.1 Bycatch in relation to fishing effort and net type $\quad 37$

4.2.2 Animals missed 38

$\begin{array}{lll}4.3 & \text { Management and conservation context } & 39\end{array}$

4.3.1 Acceptable bycatch numbers $\quad 39$

$\begin{array}{ll}\text { 4.3.2 Other sources of bycatch in Dutch waters } & 40\end{array}$

$\begin{array}{lll}4.4 & \text { Bycatch information gained from necropsies } & 42\end{array}$ 
5 Conclusions and recommendations

6 Acknowledgments

7 Quality Assurance

References 50

Justification 55

Annex I - Vessel selection 56

Annex II - Activity of sample fleet vs entire fleet 58

Annex II - Outreach and International exchange 61

Annex IV - Necropsy results 64

Annex V - Phases and evaluation of the project 73

Annex VI - Non-Dutch gillnet effort in Dutch waters 75 


\section{Executive Summary}

This study assessed the bycatch of harbour porpoise (Phocoena phocoena) in the Dutch commercial bottomset gillnet fishery, which is one of the priorities defined in the Dutch "Harbour porpoise conservation plan".

The results showed that bycatches occur in both single-walled gillnets (GNS) as well as trammel nets (GTR) and that the average annual bycatch of harbour porpoise for this fleet was 23 (95\% C.I. 2-44) during the study period. This translates to an annual mortality of between 0.05 and $0.07 \%$ of the Dutch harbour porpoise population (with a maximum worst case value of $0.3 \%$ ). ASCOBANS (resolutions 3.3 and 5.5) advises to follow the "precautionary objective to reduce by-catches to less than $1 \%$ of the best available population estimate". This study did not include mortality caused by other fishing fleets operating in Dutch waters.

From 1 June 2013 to 31 March 2017 fourteen fishing vessels were equipped with remote electronic monitoring (REM) systems. Closed-circuit television cameras (CCTV) in combination with sensors were used to obtain video footage, time and position of all net hauls. Video footage was analysed for porpoise bycatch events and correction factors were applied to account for video quality. Bycatch rate was defined as takes per unit effort (using "fishing days", "landings in tons" \& "km net length"). A non-parametric bootstrap was used to estimate confidence intervals and coefficients of variation. Bycatch numbers were estimated by applying the bycatch rate to the effort of the complete fleet.

In total 900 fishing days of the bottom-set gillnet fleet (of a total of 8133 fishing days) were analysed (11\%). Net types were categorized as single-walled gillnets and trammel nets. 760 fishing days of a total of 7756 fishing days (9.8\%) were monitored for single-walled gillnets and 140 fishing days of a total of 377 fishing days for trammel nets $(37.1 \%)$.

13 porpoises were registered during the study period, with one additional animal after the project had officially stopped. For all fishing days for which REM videos were analysed, 6 animals were registered by either the fishermen or the REM video analyses, or both. In addition 7 porpoises were reported by the fishermen during the study period when the REM was either not running, not installed or for REM days that were not analysed. A total of 8 animals were necropsied by the University of Utrecht.

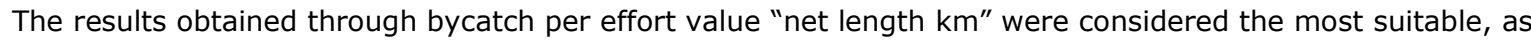
the results based on this metric had a lower variability than "ton landed" and were a more realistic reflection of effort than "fishing days". Bycatch rate (porpoises/net length $\mathrm{km}$ ) was different between net types, with 0.004 for trammel nets and 0.0006 for single-walled gillnets. The bycatch rate for all net types combined (0.0011) was applied to calculate bycatch numbers, resulting in an estimate of 88 animals for the complete study period (95\% C.I. $6-170 ;$ C.V. 14.54) and an annual average of 23 animals (95\% C.I. 2-44).

The scale of the average annual mortality for the Dutch porpoise population was assessed to be between 0.05 and $0.07 \%$ (for the study period). Using a precautionary approach, an upper value of $0.30 \%$ was determined by applying the lower C.I. value of the population size estimate and the highest available C.I. value of the bycatch estimates. Other bycatch sources, such as recreational gillnet fishery or non-Dutch gillnet vessels were not included, but their potential impacts are discussed.

This project was commissioned by the Ministry of Agriculture, Nature and Food Quality and conducted in partnership between Wageningen Marine Research (WMR, former IMARES) and Marine Science \& Communication (MS\&C), working closely with the voluntarily participating fishermen. An evaluation of the project was held by Wageningen Economic Research (Former LEI) indicating that after initial challenges in the project, a successful cooperation between all project partners was achieved.

A number of key recommendations were formulated, including the assessment of all causes of bycatch in Dutch waters, the development of a cost-effective mobile REM system, continuation of REM within the Data Collection Framework, facilitation of CITES permits to land animals and the improvement of the data collection methodology of fishing effort on an international level. 


\section{Samenvatting onderzoek "Onbedoelde Bijvangst in Beeld"}

Met het onderzoek 'Remote Electronic Monitoring (REM) van ongewenste bruinvis bijvangst in de Nederlandse commerciële staandwant visserij (september 2013 - maart 2017)' is het aantal bijvangsten en de bijvangstfrequentie van bruinvissen in de Nederlandse commerciële staandwant visserij (hierna 'staandwant vloot') onderzocht. Gedurende 46 maanden, van 1 Juni 2013 tot 31 Maart 2017, zijn 13 bruinvissen bijgevangen. Het onderzoek toont aan dat bruinvissen worden bijgevangen in zowel kieuwnetten (single-walled gillnets), als in spiegelnetten (trammel nets). Gemiddeld worden per jaar door de staandwant vloot 23 bruinvissen bijgevangen (95\% C.I. 2-44). Dit resulteert in een jaarlijkse bruinvissterfte door de staandwant vloot van 0.05 en $0.07 \%$ (met een maximum van $0.3 \%$ als een worst-case scenario wordt toegepast) van de Nederlandse bruinvispopulatie. ASCOBANS adviseert om bijvangst te reduceren tot minder dan $1 \%$ op basis van de best mogelijke populatie schatting. Op basis van het onderzoek zijn aambevelingen gedaan. Andere mogelijke oorzaken van bijvangst, zoals de recreatieve of buitenlandse commerciële staandwant visserij zijn buiten beschouwing gelaten in dit onderzoek.

De bruinvis (Phocoena phocoena) is de meest voorkomende walvisachtige in de Noordzee. De bruinvis wordt beschermd door diverse internationale en nationale verdragen en overeenkomsten, waaronder de Europese Habitatrichtlijn, OSPAR, ASCOBANS en het Nederlandse soortbeschermingsplan voor de bruinvis. Onderzoek naar bijvangst van bruinvissen door de staandwant visserij is een van de belangrijkste aanbevelingen van het soortbeschermingsplan.

Gedurende de onderzoeksperiode zijn 14 schepen uitgerust met een Remote Electronic Monitoring system (REM). Door middel van een camera's en sensoren zijn videobeelden, tijdstip van halen en de locatie van de netten verzameld. Er zijn 900 visdagen van de staandwant vloot (uit een totaal van 8133 visdagen) geanalyseerd (11\%) op bijvangst van bruinvissen aan de hand van de verzamelde videobeelden. $\mathrm{Er}$ is onderscheid gemaakt tussen kieuwnetten en spiegelnetten. 760 van de 7756 visdagen (9.8\%) met kieuwnetten zijn geanalyseerd en 140 van de 377 visdagen met spiegelnetten $(37.1 \%)$.

In totaal zijn 14 bruinvissen als bijvangst geregistreerd. Van de 14 dieren zijn 13 geregistreerd gedurende het onderzoek, 1 dier is als bijvangst gemeld nadat de datacollectie officieel was afgerond. Van de 13 bruinvissen zijn 6 dieren geregistreerd tijdens geanalyseerde visdagen. Van de 6 dieren zijn 3 zowel waargenomen tijdens de beeldanalyse, als door de vissers gemeld. 1 van de 6 bruinvissen is niet door de visser gemeld, maar wel waargenomen tijdens de beeldanalyse; 1 van de 6 is wel door de visser gemeld, maar niet waargenomen tijdens de beeldanalyse; 1 van de 6 is met de kwaliteitscontrole van de beeldanalyse waargenomen, maar niet door de visser gemeld en niet tijdens de eerste beeldanalyse waargenomen. Van de 13 geregistreerde bruinvissen zijn 7 bruinvissen door de vissers gemeld tijdens het onderzoek op momenten dat het REM systeem niet functioneerde, niet was geïnstalleerd of waarvan de videobeelden niet zijn geanalyseerd. In totaal zijn 8 dieren voor pathologisch onderzoek naar de Universiteit Utrecht gebracht.

De bijvangstfrequentie is gedefinieerd als het aantal bijvangsten per inspanningseenheid. In dit onderzoek zijn drie types inspanningseenheden gebruikt: (1) visdagen; (2) aangelande vis in ton en (3) km netlengte. De bijvangstfrequentie is berekend voor alle nettypes bij elkaar, en apart voor kieuwnetten en spiegelnetten. Alleen inspanningseenheden die voor de hele vloot beschikbaar zijn, kunnen worden gebruikt. Het aantal bijgevangen dieren wordt namelijk berekend door de mate van bijvangst te vermenigvuldigen met de inspanning van de hele staandwant vloot. Correctie factoren zijn berekend en toegepast voor de videokwaliteit van de videobeelden. Er zijn 95\% betrouwbaarheidsintervallen en variatiecoëfficiënten voor de bijvangst frequentie berekend. Bijvangst per km netlengte wordt beschouwd als de meest geschikte inspanningseenheid omdat het een betere weergave is van de inspanning dan "visdagen", en de resultaten hebben een lagere variatiecoëfficiënt dan "aangelande vis (ton)". 
Bijvangst komt voor in beide nettypes. De bijvangstfrequentie tussen kieuwnetten en spiegelnetten verschilt, waarbij de mate van bijvangst voor spiegelnetten hoger is. Echter de visserij-inspanning van kieuwnetten was hoger gedurende de onderzoeksperiode dan voor spiegelnetten. De bijvangstfrequentie (bruinvissen/km netlengte) voor spiegelnetten is 0.004 en 0.0006 voor kieuwnetten.

Onderstaande tabel geeft een overzicht van de bijvangst zoals deze is berekend over de hele onderzoeksperiode, gemiddeld per jaar en voor de nettypes gecombineerd en per type.

Tabel "Samenvatting": Overzicht bijvangst bruinvissen door de Nederlandse commerciële staandwant visserij (onderzoeksperiode: 1 juni 2013 tot 31 maart 2017).

\begin{tabular}{|c|c|c|c|}
\hline $\begin{array}{l}\text { Berekende bijvangst } \\
\text { onderzoeksperiode }\end{array}$ & Visdagen & $\begin{array}{c}\text { Aangelande vis } \\
\text { (ton) }\end{array}$ & Netlengte $(\mathrm{km})$ \\
\hline $\begin{array}{c}\text { Kieuw- en } \\
\text { spiegelnetten }\end{array}$ & $\begin{array}{c}71 \text { dieren } \\
(95 \% \text { C.I. 5-137) }\end{array}$ & $\begin{array}{c}109 \text { dieren } \\
(95 \% \text { C.I. } 0-244)\end{array}$ & $\begin{array}{c}88 \text { dieren } \\
(95 \% \text { C.I. } 6-170)\end{array}$ \\
\hline Kieuwnetten & $\begin{array}{c}54 \text { dieren } \\
(95 \% \text { C.I. } 0-121)\end{array}$ & $\begin{array}{c}95 \text { dieren } \\
(95 \% \text { C.I. } 0-239)\end{array}$ & $\begin{array}{c}44 \text { dieren } \\
(95 \% \text { C.I. } 0-103)\end{array}$ \\
\hline Spiegelnetten & $\begin{array}{c}7 \text { dieren } \\
(95 \% \text { C.I. } 0-16) \\
\end{array}$ & $\begin{array}{c}10 \text { dieren } \\
(95 \% \text { C.I. } 0-26) \\
\end{array}$ & $\begin{array}{c}5 \text { dieren } \\
(95 \% \text { C.I. } 0-12) \\
\end{array}$ \\
\hline $\begin{array}{l}\text { Berekende bijvangst } \\
\text { gemiddeld per jaar }\end{array}$ & Visdagen & $\begin{array}{c}\text { Aangelande vis } \\
\text { (ton) }\end{array}$ & Netlengte (km) \\
\hline $\begin{array}{c}\text { Kieuw- en } \\
\text { spiegelnetten }\end{array}$ & $\begin{array}{c}19 \text { dieren } \\
(95 \% \text { C.I. } 1-36)\end{array}$ & $\begin{array}{c}28 \text { dieren } \\
(95 \% \text { C.I. } 0-64)\end{array}$ & $\begin{array}{c}23 \text { dieren } \\
(95 \% \text { C.I. } 2-44)\end{array}$ \\
\hline Kieuwnetten & $\begin{array}{c}14 \text { dieren } \\
(95 \% \text { C.I. } 0-32)\end{array}$ & $\begin{array}{c}25 \text { dieren } \\
(95 \% \text { C.I. } 0-62)\end{array}$ & $\begin{array}{c}12 \text { dieren } \\
(95 \% \text { C.I. } 0-27)\end{array}$ \\
\hline Spiegelnetten & $\begin{array}{c}2 \text { dieren } \\
(95 \% \text { C.I. } 0-4)\end{array}$ & $\begin{array}{c}3 \text { dieren } \\
(95 \% \text { C.I. } 0-7)\end{array}$ & $\begin{array}{c}1 \text { dier } \\
(95 \% \text { C.I. O-3) }\end{array}$ \\
\hline
\end{tabular}

De bijvangststerfte door de staandwant vloot van de Nederlandse bruinvispopulatie is berekend door gebruik te maken van de bijvangstberekening per jaar (19, 28 en 23 dieren) in combinatie met de laagste populatieschatting beschikbaar voor de onderzoeksperiode zomer 2015 (41299 (95\% C.I. 21194-79256)). Dit resulteert in een jaarlijkse sterfte door bijvangst in staandwant vloot van 0.05 tot $0.07 \%$ van de Nederlandse bruinvispopulatie. Een maximum waarde van $0.3 \%$ is berekend door de hoogste C.I. voor aantal bijvangsten (62) en de laagste C.I. voor populatiegrootte (21194 bruinvissen) te gebruiken. Andere mogelijke oorzaken van bijvangst, zoals de recreatieve of buitenlandse commerciële staandwant visserij zijn buiten beschouwing gelaten in dit onderzoek.

De belangrijkste aanbevelingen naar aanleiding van dit onderzoek zijn:

1) Onderzoek de mate van bijvangst op het NCP door andere visserij segmenten (zoals de buitenlandse commerciële - en recreatieve staandwantvisserij);

2) Ontwikkel een kosteneffectief mobiel REM systeem in samenwerking met de visserijsector;

3) Continueer REM monitoring in samenwerking met de visserijsector, waarbij gekeken wordt naar alle beschermde soorten (Data Collection Framework);

4) Legaliseer het aanlanden van bijgevangen bruinvissen voor (pathologisch) onderzoek;

5) Verbeter de datacollectie methodiek van visserij inspanning op internationaal niveau.

Dit onderzoek is uitgevoerd in opdracht van het Ministerie van Landbouw, Natuur en Voedselkwaliteit (LNV) en uitgevoerd door Wageningen Marine Research (WMR, voorheen IMARES) en Marine Science \& Communication (MS\&C) en mogelijk gemaakt door de deelnemende vissers. De coördinatie en afstemming met alle betrokken partijen was een essentieel onderdeel van het project. Het onderzoek kende vier fasen: (1) Aanloop; (2) Installatie REM systemen; (3) data verzameling en (4) data analyse. De conclusie van een evaluatie van het onderzoek door Wageningen Economic Research (voorheen LEI) is dat na een moeizame start (wantrouwen vanuit de sector, zorgen omtrent privacy en omgang met data, technische problemen, tongquotum schaarste) een succesvolle samenwerking tussen alle betrokken project partners is bereikt. 


\section{Introduction}

Bycatch in gillnet fishery has been identified as the main cause of human-induced mortality for small cetaceans worldwide (e.g. Jefferson and Curry 1994). Concerns about the sustainability of bycatch of harbour porpoise (Phocoena phocoena) in European waters has led to a number of agreements aimed to monitor and reduce bycatch. The 'Bergen Declaration' from 2002 urges fishery authorities of the North Sea countries to aim for a reduction of bycatch of harbour porpoises. It follows requirements of the Agreement on the Conservation of Small Cetaceans of the Baltic and North Seas (ASCOBANS) and the EU Habitats Directive to reduce overall human induced mortality to below $1.7 \%$ of the best population estimate, and to apply the precautionary principle, aiming to reduce bycatch to less than $1 \%$.

Since 2005 the EU members states are under the obligation to implement observer projects in specific segments of the fishing fleet specified in EU Regulation 812/2004 (EU 2004). Conditions are attached to this obligation: for example, the obligation is applicable to vessels with an overall length of at least 15 metres and to specific areas that do not encompass the entire North Sea. These conditions are based on the insights into the numbers of incidental catches by season, area and type of net prior to 2004. At that time porpoises did not regularly occur in the waters of the south-eastern North Sea. A significant shift in porpoise distribution occurred over the last 20 years (e.g. Camphuysen, 2004; Hammond et al. 1995, 2002, 2013, 2017), making the harbour porpoise currently the most common cetacean in the Dutch part of the North Sea. As a result of this, the majority of the area in which the fisheries operations were carried out (ICES area 4c) is not governed by the Regulation. In addition, the Dutch set net fisheries were not monitored pursuant to the EU Regulation since virtually all vessels are shorter than 15 metres. Monitoring by observers is required in any gillnet fishery of vessels of $15 \mathrm{~m}$ or longer, fishing with bottom set gillnets or entangling nets with mesh sizes of $80 \mathrm{~mm}$ or more in ICES divisions VIa, VIIa and b, VIIIa, b and c, and IXa. As none of the Dutch gillnet fishers operate in these areas, this actually means that for the Dutch fishery no monitoring requirements were applicable from EU regulation 812/2004. The recent revision of the EU Data Collection Framework (DCF) mentions monitoring of bycatch of other species, including cetaceans, from January 2017 onwards. However the selection of fisheries for monitoring and the on board sampling practices under the DCF are not specifically adapted to cetaceans yet (ICES, 2017a).

The above mentioned distribution shift of the North Sea harbour porpoise population has led to an overlap of this species with gillnet fishery in Dutch waters. Pathological examination of stranded harbour porpoise indicated that bycatch occurs regularly (e.g. IJsseldijk et al. 2018, Scheidat 2015). As a long-lived species with a low birth rate, porpoises are especially vulnerable to any harmful human activity. Based on the knowledge available, it was proposed that bycatch events might be reaching unsustainable levels for the Dutch porpoises (Scheidat et al. 2013). This is reflected in the Dutch "Harbour porpoise conservation plan" ("Bruinvisbeschermingsplan") which identifies the estimation of bycatch rates and mitigation methods as one of the research priorities for the Netherlands (Camphuysen \& Siemensma 2011). Consequently both the environmental and the fishery departments of the Dutch Ministry of Agriculture, Nature and Food Quality (former Ministry of Economic Affairs) decided to conduct a designated project to investigate the bycatch of porpoises occurring in the Dutch commercial gillnet fishery.

The Dutch commercial gillnet fleet is a small-scale artisanal fishing operation. Artisanal fishery is typically defined as fisheries utilizing low technology gears and vessels to target a variety of species for subsistence and local markets (e.g. FAO/RAP/FIPL 2004). The term "commercial" means that these vessels have a governmental license, which includes the registration of the vessel as a fishing vessel. There are also recreational gillnet fishermen operating along the Dutch coastline. In this report, when we refer to the Dutch gillnet fishery, we address only the commercial fishery operating under the Dutch flag. 
Different methods of obtaining data on bycatch events during fishing operations are available. The most commonly used are on-board observer programs. However, monitoring of the Dutch commercial gillnet fleet with observers is challenging, primarily due to the small size of some of the vessels which are often run with only one crew member, thus providing very limited space on board. For the Netherlands a pilot study was done in 2011 on one gillnet vessel to investigate the efficacy of remote electronic monitoring (REM) on Dutch gillnet fishing vessels (Van Helmond \& Couperus, 2012). Based on the promising results from this pilot study, as well as the priorities outlined in the Harbour Porpoise Conservation Plan (Camphuysen \& Siemensma, 2011) and results of similar Danish studies (e.g. Kindt-Larsen et al. 2012a) it was decided to conduct a REM study with the goal to sample 5 to $10 \%$ of the Dutch gillnet fleet fishing effort in the time period from June 2013 to March 2017.

Aim of this project was to assess the extent of harbour porpoise (Phocoena phocoena) bycatch rate and numbers in the Dutch commercial bottom set gillnet (single-walled bottom set gillnets and trammel nets) fishery. 


\section{Materials and Methods}

\subsection{Project organisation}

The project was commissioned in December 2012 by the Ministry of Agriculture, Nature and Food Quality (LNV, former Ministry of Economic Affairs), involving both the fishery as well as the nature conservation departments.

This project was conducted in partnership between Wageningen Marine Research (WMR, formally IMARES) and Marine Science \& Communication (MS\&C). There was close coordination with the participating fishermen in the data collection process. The transport and pathological research of landed bycaught porpoises was done with the Department of Pathobiology of University of Utrecht.

The coordination between all project partners was a vital aspect of this project. WMR coordinated the installation of REM systems on board, data collection, analysis and overall project management. MS\&C acted as an intermediate and liaison between all project partners. Members of the project team visited the harbours when needed and contacted the participants by phone and vice versa. Rems Cramer, participating fisherman and representative of the Kenniskring Staandwant visserij (Dutch Fisheries Expert Group on gillnet fisheries), acted as spokesman for the sector and in particular the participants. A number of meetings were held with both the Ministry of EZ, the Dutch Fishermen's Association (Nederlandse Vissersbond) and the Fishermen's organisation VisNed and they were contacted ad-hoc when needed. The latter two also have been consulted regarding the participation of fishermen.

The project was divided into four phases: project initiation (phase 1); installation of REM (phase 2); data collection (phase 3 ) and data analysis and results (phase 4) (see Annex V). The project met several hurdles in phase 1 and phase 2 . There was a lot of caution and distrust within the fleet to participate. One reason was that there had been previous negative experiences with these type of projects. Another problem was that in the years prior to the project start a notable number of harbour porpoise carcasses appeared on the beaches that were showing dramatic cuts of unknown origin. When hypothesising on the causes, fishermen were accused of mutilating bycaught porpoises and setting them overboard. In 2014 evidence was found that grey seals were catching and feeding on porpoises and that these predators were the cause of the observed injuries - not the fishermen (Haelters et al. 2012, Bouveroux et al. 2014, Leopold et al. 2015). Other challenges included that the REM system could not be installed on all vessels without installing extra power capacity and that additional permissions for pulse fisheries to fish for sole resulted in a short supply of sole quota for most of the participating fishermen. Subsequently the prices to rent quotas increased and the fishing activities of the fishermen of the project were impaired, as they could not fish for sole as they used to do. After consultation with the Ministry of Economic Affairs (EZ), the Kenniskring Staandwant visserij, the NL Vissersbond and VisNed, the participating fishermen applied successfully at the Ministry for a science quota for sole.

A detailed overview of these phases as well as the results of an evaluation meeting 14 December 2016 (Evaluatiebijeenkomst "Onbedoelde bijvangst in beeld") of the project facilitated by Wageningen Economic Research (Former LEI), as part of the Dutch Fisheries Expert Group on gillnet fisheries (Kenniskring Staandwant) is given in Annex V. The meeting was held based on a request from the sector to the Kenniskring, with the aim to share the knowledge and experience about carrying out the project related to interaction and participation between involved parties, positive or negative, and to use lessons learned in future projects with the (gillnet) fisheries fleet. The meeting concluded that cooperation based on respect and trust had proven to be successful; a cooperative attitude of the government facilitating the project - including supporting the use of scientific quota - to get insight in bycatch and an independent party acting as liaison between parties both appeared of value; clear agreements were made with all partners about the use of collected data beforehand. 


\subsection{Participating fishing vessels}

To obtain a representative sample of a population one needs to select a random sample. However, applying random sampling to a fishing fleet (in our case the Dutch commercial bottom-set gillnet fishery) is a well-recognized challenge in monitoring programs (Benoît and Allard, 2009). Specifically for the Dutch fleet, these are the key constraints that had to be considered when choosing the participating vessels:

Technical requirements on REM system installation: The selected vessel needs to provide a dry area for the computer of the REM system to be installed. So, any vessel without a cabin or a frame to attach the camera could not be used (these are most vessels with less of $7 \mathrm{~m}$ length). This precludes a large portion of the fleet.

Minimum fishing activity: Funds were available to install 10 to 12 vessels with an REM system. The aim was to cover at least between 5 and 10 percent of the fishing activity of the complete fleet. An analysis of the fishing activity in the year 2012 showed that around $50 \%$ percent of all vessels were active for less than 20 fishing days per year. If these vessels were selected to participate, their low fishing activity would mean that the overall fleet coverage target would not be met. Thus it was decided to prioritize the selection for vessels that fish at least for 20 days per year.

Voluntary participation: The Dutch ministry was responsible to ensure participation of fishing vessels in this project. Fishing vessels were selected in an iterative process (see Annex I) in close cooperation with the Dutch Fishermen's Association (Nederlandse Vissersbond) and VisNed under the auspices of the ministry.

With these constraints in the selection process in mind we tried to approximate a random selection of fishing vessels, or more accurately to approximate a representative sample of the overall fleet, through an in-depth comparison of past fishing behaviour of the complete fleet in relation to the past fishing behaviour (e.g. considering location, net gear, season) of our potential fishing vessels. Details of our description of this process which describes the characteristics (e.g. net use, area coverage, seasonal fishing effort) of our sampling population as well as of the entire population was presented as a non-public interim report to EZ, a summary can be found in Annex I of this report.

\subsection{Net types monitored}

The net type used during fishing operations depends on the target species of the fishermen at the time. Sole is by far the primary target species of the commercial Dutch gillnet fishers. It is normally fished upon from March till October. From October till March, some fishermen switch to cod, turbot and brill and to a much lesser extent to plaice and flounder. A few gillnet fishers target mullet in the Delta area and the Wadden Sea. A single gillnet fisher fishes for seabass near the Maasvlakte. Apart from sole, the catches of the other target species were at such a low level during the period of study, that they hardly dominated the catch. As a consequence, the fishers landed a mixture of the species mentioned.

The nets used can be classified into three main categories:

1. Gillnets: the mesh is slightly smaller than the body circumference of the fish, as a result of which the fish are trapped by their gills.

2. Tangle nets: the mesh is equal to or larger than the body circumference of the target species. The net is set more loosely and when in contact with the net the fish tries to escape, but becomes increasingly tangled.

3. Trammel nets: These nets are comprised of three layers. Two layers of coarse-mesh sandwich a third net, in the middle, with a finer mesh.

A wide range of mesh sizes are available within the aforementioned categories. The following paragraphs give a brief description of the nets most frequently used in Dutch gillnet fisheries. 
Within the EU definition (Appendix IV of the 2010/93/EC) the following net types are considered single-walled bottom set gillnets (GNS) (figure 1 ).

Cod nets (gillnets)

Cod nets without coarse-meshed nets are referred to as gillnets. In general, these nets have a mesh size of between 100 to $160 \mathrm{~mm}$, depending on the expected fish size. The base of the net is weighted (usually with lead) and to remain in a vertical position in the water column, floats or a headline are attached to the top. The majority of the Dutch fisheries segment uses multi-mono filament as net material. In a few instances monofilament or nylon is used. The average height of the nets is $1.20-$ 2.00 metres. The effective height of the nets is lower due to the water currents: these push the nets towards the seabed. The effective height of the nets can vary between 0 and 150 centimetres, depending on the strength of the water currents. Virtually no turbot or brill are caught with these nets since these fish are too large to become caught in the mesh. In general, the nets are set for a maximum of 24 hours. These nets are often used from the autumn until the early spring, both on flat seabed and near wrecks.

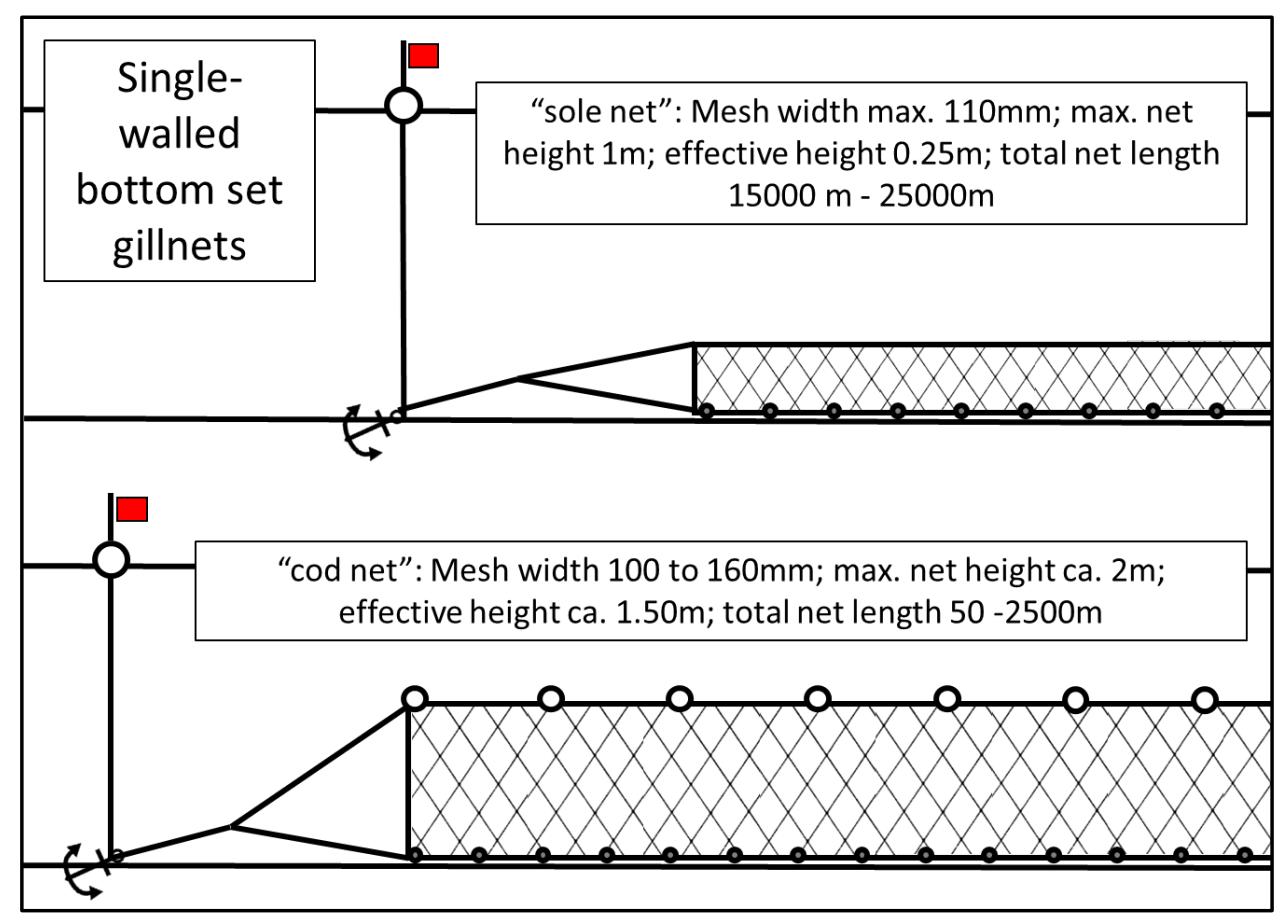

Figure 1. Schematic description of the most commonly used single-walled bottom set gillnets (GNS) in the Dutch fishery

Sole nets (tangle nets)

Sole nets differ from cod gillnets and trammel nets in that the mesh is smaller (a maximum of 110 $\mathrm{mm}$ ) and that the nets are not as high (a maximum of 1 metre). As the nets have no floating upper line the nets can lie flat on the seabed when the water currents are strong. These nets are generally set for one night, depending on the expected catch and the amount of fouling. Sole fishing begins in March to May and continues until September and October. On the basis of this description these nets are tangle nets (NB: Belgian fishers fish for sole with trammel nets, but of a smaller mesh than the trammel nets reviewed below).

\section{Bass nets}

These are also single walled gillnets, similar to cod nets. The bass nets used along the Dutch coast vary in height according to location. The nets used along the beaches in general have a maximum height of 1.5 metres. The nets used in the vicinity of underwater structures, like manmade seawalls and block dams, are of a maximum height of 3 metres. The nets have a mesh size of 90 to $130 \mathrm{~mm}$. Bass nets are primarily used in the summer. 
The following category of net is the three-walled trammel net, which is categorized as trammel net (GTR) by the European Commission (Appendix IV of the 2010/93/EC) (figure 2).

Trammel nets for flatfish and cod

These nets consist of a small meshed layer of netting, sandwiched between two layers with a coarser mesh (300 to $500 \mathrm{~mm}$ ). Fish swimming through the coarse-meshed net come into contact with the fine-meshed net $(70-80 \mathrm{~mm})$ and propel themselves and the fine-meshed net through the back coarsemeshed net. They are then trapped in what is in effect a bag of the fine-meshed net.

Trammel nets offer the advantage of catching dab, brill and turbot together with cod. These nets are used for a period similar to that of cod gillnets, and are also used on flat seabeds and near ship wrecks. In some years cod dominates the catches in trammel nets and can be considered the target species, but this is variable (and was not the case during this study).

Even within one net type mesh sizes and net height can vary considerably. What type of net is actually deployed highly depends on the fish availability (e.g. also the size) and fishermen routinely switch between net types.

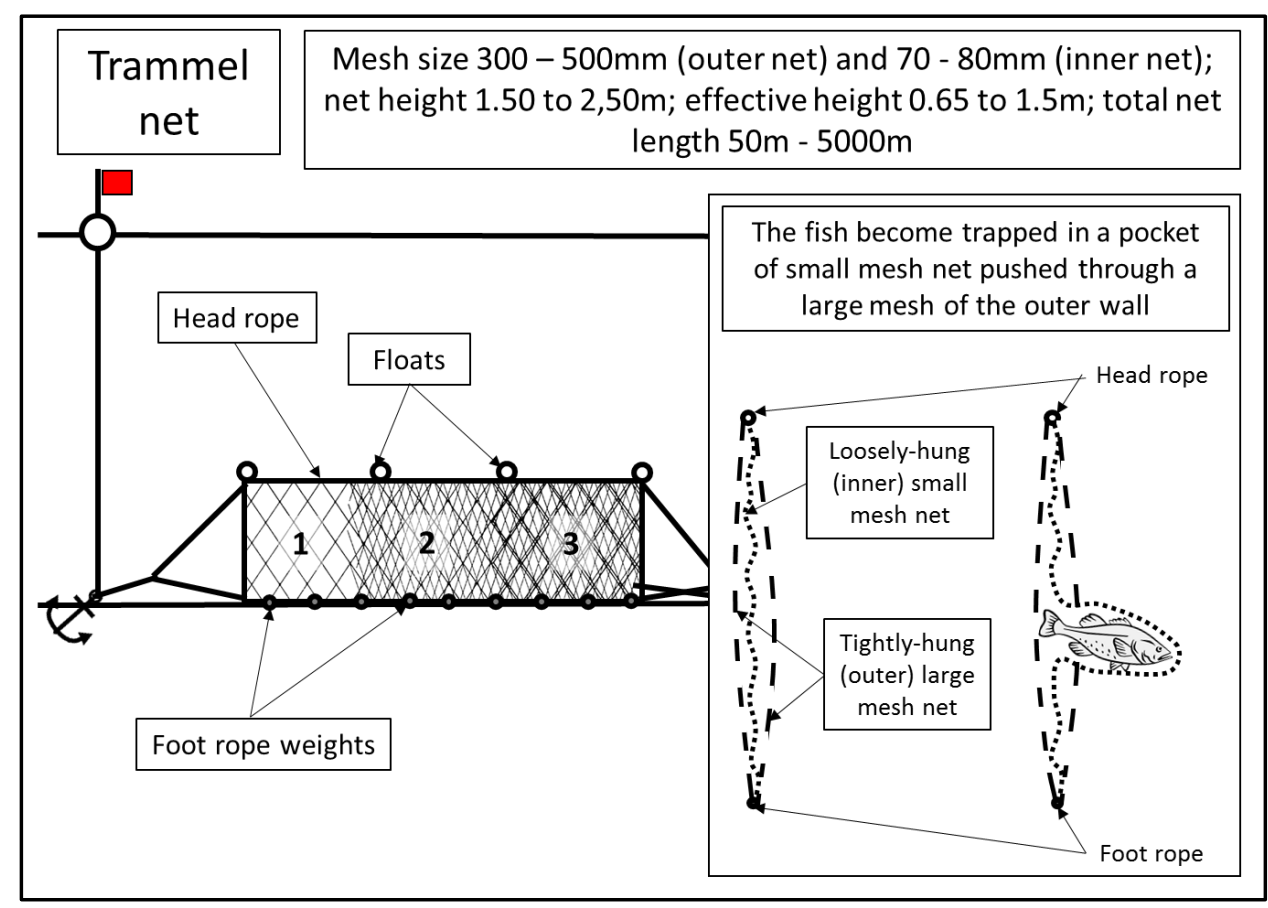

Figure 2. Schematic description of trammel nets (GTR) used in the Dutch fishery. 1: one outer net, 2: one outer net with the inner net and 3: the two outer nets with the inner net inside.

\section{Soak time}

In general, soak time differs between net types used. For example, nets aimed at sole are set according to the tide, with fishing vessels aiming to set and haul the nets during slack tide. So these nets have a soak time of at least 12 hours. With trammel nets aiming at cod, the nets are set to fish overnight. This means that generally nets are set in the evening and retrieved in the morning. A long soak time, in particular in summer, can lead to scavengers (e.g. crabs) damaging the catch. This is why normally nets are set for a maximum of 24 hours. However, during periods of very low catches the nets may be set for 48 hours. 


\subsection{Installation of Remote Electronic Monitoring (REM) systems}

Vessels were equipped with the REM system developed by Archipelago Marine Research Ltd, Canada. The system used consisted of a control box with a 500 - 1000 GB replaceable hard drive, a hydraulic pressure sensor, a position sensor (global positioning system; GPS) and 1 or 2 waterproof armoureddome closed-circuit television (CCTV) cameras (figure 3), one analogue and one digital with a higher resolution (figure 4 ). The cameras were positioned in a way to view the area where the net would break the water when hauled aboard. When two cameras were used they were positioned in a way that the net could be seen from different angles.

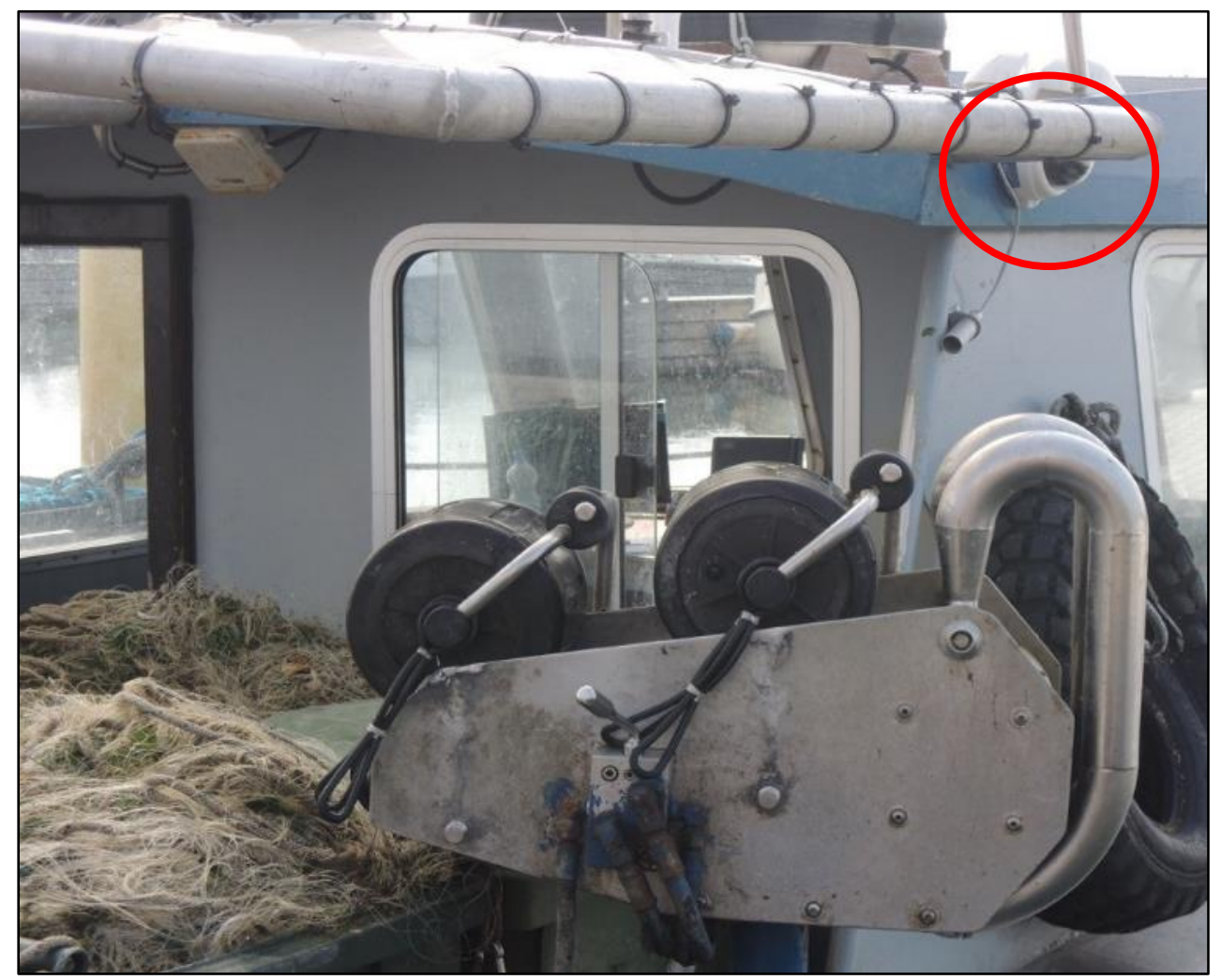

Figure 3. An example of the camera placement on board one of the participating vessel. The red circle shows the position of the camera [photographer: Marije Siemensma, MS\&C].

In three cases the limited space on the vessels only allowed for the installation of a single camera. The control box included a computer that monitored sensor status and activated image recording. All components were connected to the control box placed in the wheelhouse. The hydraulic pressure sensor was mounted on the high pressure side of the hydraulic system recording the pressure activity in the net drum. The lenses of the CCTV cameras varied from 2.9 to $12 \mathrm{~mm}$ (most commonly 3.6 and $6 \mathrm{~mm}$ ) and frame rates were set to 5 frames per second (fps). The size of each recorded frame was $640 \times 480$ pixels in the analogue cameras and $1074 \times 768$ in the digital cameras.

The REM system on all vessels was programmed to switch on when leaving port and off when entering port, determined by the GPS positions of the outer range of the harbours. On all systems the rotation sensor on the power driven drum triggered the video recording. In one case in which the sensor could not be used because of technical reasons, video recording was triggered by the GPS when the vessel left port. When the hard drive was 70 to $90 \%$ full, the fishermen either contacted the project team or mailed the hard drive to the institute. Members of the project team also regularly passed by the vessels to check on progress and exchange hard drives. Fishermen always had one extra hard drive available. For 6 vessels the power supply on board was not sufficient to run the REM system while hauling the nets. For these vessels a new and/or additional power supply was installed. 


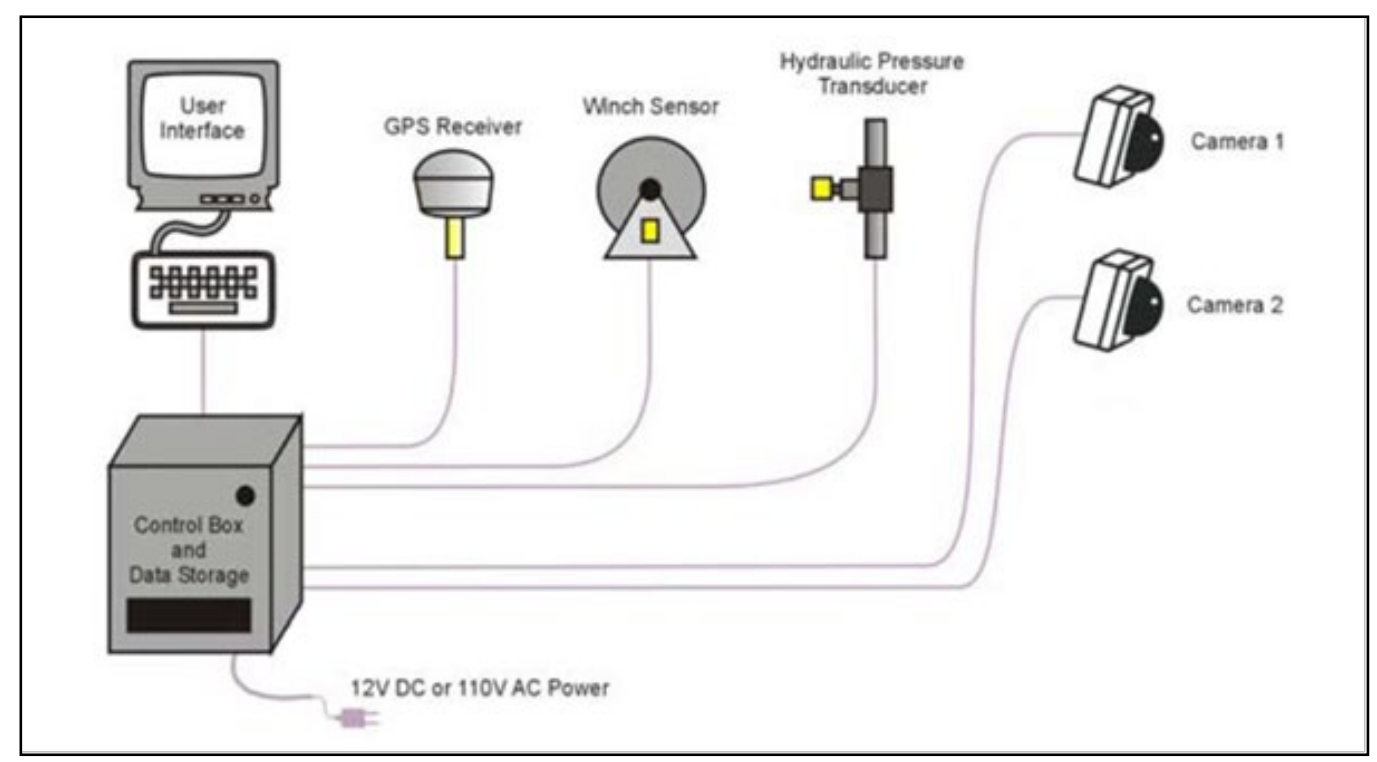

Figure 4. Schematic diagram of the setup of the electronic monitoring (adapted from Archipelago Ltd.). On three vessels only one camera could be installed on board.

\subsection{Bycatch registration}

The participating fishermen agreed to register all bycatches, independent if the REM systems were up and running. However, only the bycatches that were registered by the fishermen and/or the REM observers for those days that REM footage was analysed were used for the calculation of bycatch rates, because only the analysed REM footage is can be considered a systematically collected sample of effort and bycatch.

Results of the pathological investigations of all necropsied porpoises can be found in Annex IV. Fishermen participating in this study received a permission to land dead bycaught porpoises, which is otherwise illegal.

\subsection{Data analyses}

\subsubsection{Electronic monitoring data}

Beginning and end of each fishing trip and haul were indicated and analysed by use of the REM Interpret (EMI) software (Europe release, Archipelago Ltd. V.11.3. 11189). EMI displays time series of GPS tracks on a map and hydraulic pressure and vessel speed on a time line.

EMI also integrates synchronized playback of all camera views to the visual map of sensor data, permitting viewers to watch both GPS tracks and the time-linked video footage concurrently. For every haul the working of each camera was indicated as "complete" or "incomplete". If "incomplete", the percentage working was given. Quality of the footage like focus, cleanliness and lighting for each camera was indicated as low, medium or high. In addition - as a general indicator of quality - the video analyser gave a percentage as an expression of the probability of seeing a bycaught porpoise. Every footage of a (possible) bycatch of a porpoise was clipped, including sensor data, date/time and geographical position. The speed of image playback depended on image quality and varied between 8 to $10 x$ the original speed. A customized program was written to extract the data needed in a format allowing it to link with the existing VISSTAT data base, containing official logbook information. 


\subsubsection{Bycatch calculation}

To estimate the bycatch rate of harbour porpoises for a fishing fleet two key values are needed. First, a measurement of fishing effort and second the number of bycatches in the monitored section of the fleet.

To consequently obtain a total number of bycatches for an entire fleet (or a section thereof) the bycatch rate is extrapolated, using effort as the auxiliary value (raising factor). Below the methodological background for the estimation of fishing effort, bycatch rate and bycatch numbers is provided.

\subsubsection{Fishing effort}

One of the main challenges is to obtain a measurement of fishing effort that is available for both the sampled section of the fleet as well as the complete fleet. For our target fleet, the source of this data comes from the logbook that fishermen fill out after a fishing trip. This logbook is part of the Electronic Recording and Reporting System (ERS) as part of the EU system for fisheries control. Despite the word "electronic" this logbook is filled out manually by the fishermen and is sent to the control agency where it is entered into a database on the fishing activity. It is important to note that the logbook system is not designed for data assessment or scientific analyses, but to monitor compliance. An extract of this database (VISTAT) is accessible for research purposes.

The values that can be related to fishing effort and that are considered most consistent and reliable in the VISSTAT database are "days at sea", "fishing days", and "weight of landed catch". Other values, such as number of hauls, net length, soak time, mesh size and net height also provide information on fishing effort. However, these are often not available for the entire fleet, which means they cannot be used to extrapolate to overall fishing effort. In some cases, such as net length, the data was provided inconsistently and/or using different unspecified scales, making it necessary to correct the data for all entries with additional information (see 2.6.2.1.3).

For the analysis in this project three measurements of effort for the Dutch commercial gillnet fleet were used: "fishing days", "tons catch landed" and "net length km". The data was extracted for all Dutch commercial gillnet fishing activities, excluding the IJsselmeer area (ICES quadrant 34F5).

\subsection{Fishing days}

Fishing days were defined as days when fishing activity was registered in the logbook. This can be different to "days at sea" in particular for larger vessels that might spend a week at sea but only fish several days. The number of hauls conducted during one day can vary per fishing day.

\subsection{Tons catch landed}

The logbook database was used to determining the total quantity (in ton weight) of all species landed (and reported) in the Dutch commercial gillnet fishery per fishing day.

\subsection{Net length $\mathrm{km}$}

As mentioned above, net length was not available for all fishing days. In addition, net length was entered in the logbooks using three different measurements: meter, kilometre and number of nets (with one net having a length of $50 \mathrm{~m}$ ). As the type of unit ( $\mathrm{m}, \mathrm{km}$, net number) is not provided in the database, the values of net length cannot be used directly without some adjustment. To be able to obtain a trustworthy and consistent value for net length, a similar approach as described in Jongbloed et al. (2012) was applied. First an overview of likely net lengths was compiled using the data from the logbooks when available, second the information available from the Jongbloed et al. (2012) work was added to fill in gaps. This information was then evaluated and completed with input from the Kenniskring Staandwant visserij (Dutch Fisheries Expert Group on gillnet fisheries). The net length deployed could not be determined per fishing day, but was assessed per year and vessel. This was done separately for single-walled gillnets and trammel nets and then added into the database per vessel, providing a value of average net length per net type per year for each fishing day. It is important to note that it is not known if the net was set more than once per day (number of hauls), so this value is an minimum value of net length set per day. 


\subsubsection{Bycatch numbers}

Bycatches of harbour porpoise were registered either during the REM analyses, and/or on-board by the fishermen. For the calculation of bycatch rate only those porpoises that were registered during analysed REM days were used, as the analysed video footage is the systematic sample of effort and bycatch in the fishery. The resulting bycatch rates were then extrapolated to the effort of the whole fleet effort to obtain bycatch numbers.

\subsubsection{Correction factor}

To determine a correction factor we drew on approaches developed for distance-sampling methodology during survey work (Buckland et al. 2001). During distance-sampling the assumption is that animals during a survey can be missed on the transect line either because of the availability bias (animals are there but not visible, e.g. diving) and/or the observer bias (the observer misses animals). The availability bias would refer to animals falling out of the net while underwater and not drifting in the vicinity of the vessel. The occurrence of this has not yet been quantified (see section 4.4.2). For the REM project we addressed the observer bias by looking at two components - first the reduction in video quality that would reduce the probability of the observer to detect a porpoise and second the chance of an observer (or fisherman) to miss an animal although it is visible.

Quality of the video footage (for the REM fishing days analysed) was defined using parameters describing 1) the quality of the video (e.g. clarity, light conditions) and 2) the completeness of the video (e.g. sections missing because of power failures). These two values were multiplied with each other to provide a value of how much of the REM footage could effectively be observed. This was averaged per fishing day and resulted in a "corrected fishing day" effort value for the sampled section of the fleet. This means that if either the quality of the video was low or the video was incomplete the final score would reflect this. As an example, if the video was only complete for $60 \%$ of the time $(0.6)$, but the quality was $90 \%(0.9)$, the final score would be $54 \%(0.54)$.

The assumption that all animals are seen during the REM analysis or by fishermen on board is not true. Bycaught animals can be missed both by the observers and/or the fishermen. To attempt the calculation of a correction factor we randomly selected about $10 \%$ of all REM footage ( 87 fishing days of 900 total days) as an anonymized sub-sample of the REM footage. The subset was analysed by independent observers that reviewed the footage with $4 x$ to $8 x$ the speed of the footage. The aim was to see if there were any bycatches detected in the sub-sample that had not been noted during the first REM data analysis. In addition, to check if the observers conducting the control would miss bycatches, we also added (randomly and anonymized) the 5 fishing days with known bycatch to this data set.

\subsubsection{Calculation of bycatch rates}

Estimates of porpoise bycatches per unit of fishing effort are known as ratio estimates (e.g. Saila 1983). Calculations were done by dividing the number of bycatches (see above) by these three sources of effort (fishing day is corrected for video quality):

1) corrected fishing day,

2) tons kg fish landed per corrected fishing day and

3) net length $\mathrm{km}$ per corrected fishing day

for the monitored section of the fleet.

The final bycatch rates were calculated for both net types combined, as well as separately per net type (single-walled gillnets and trammel nets).

When total bycatch is estimated with a ratio estimator a small sample size can lead to bias (a systematic over- or underestimate) (e.g. Rao 2000). One method to adjust for this is the use of a resampling technique called bootstrap (e.g. Hall 1999). This procedure consists of sampling repeatedly with replacement from the data, allowing the calculation of variances and confidence intervals without having to make assumptions about the distribution of the variables. 95\% Confidence Intervals (95\% C.I.) and Coefficients of Variation (C.V.) calculated using a non-parametric bootstrap procedure (normal) with 1000 repetitions. The calculations were done using the program R (version 3.5.1). 


\subsubsection{Estimation of animals caught}

The estimated bycatch rate(s) for all net types as well as per net type were multiplied to the overall fishing effort for the complete study period (1. June 2013 to 31. March 2017) derived from the VISSTAT database. This resulted in a total estimate of harbour porpoise bycatches for that time period. An average monthly value was calculated (using the 46 months of the study period) as well as an average annual value (by multiplying the monthly average by 12 ). The same method was applied to the net type specific bycatch rates (single-walled gillnets and trammel nets). In addition, the overall bycatch rate was also applied to the overall effort data for the years 2014, 2015 and 2016. 


\section{Results}

\subsection{Monitoring effort}

\subsubsection{Participation and installation of vessels}

The installation and successful data collection using the remote electronic monitoring (REM) system met with a number of hurdles. In 2013 an iterative process was started with the ministry of EZ and an expert group "Kenniskring Staandwant visserij" (Dutch Fisheries Expert Group on gillnet fisheries), to obtain a list of vessels to participate in the project (for details see Annex I). After an initial selection was done, the vessel operating from the town of Urk stepped out of the project in 2013. In January 2014 six of the initially selected vessels were equipped with the REM systems. Another four vessels had the REM system installed by the end of February 2014, thereby totalling the number of equipped vessels to ten. Several of these vessels got additional power supplies installed, which led to added costs and delays. This included a vessel which originally was considered too small to install an REM system, however, together with the cooperation of the fisherman and motivated by the project team, the installation company found a solution. One of the four vessels equipped in February 2014 was on the original list of selected vessels, however fell off that list due to a change in its fishing activities. It had taken up its fishing activities again in December 2014, which made it possible for this vessel to rejoin the project. In the second half of 2015 this same vessel quit the project because it was sold to a UK company. In the last quarter of 2014 and the first quarter of 2015 efforts were made to select four additional vessels for participation to bring the total number of participating vessels to twelve. In September 2015 one of the 12 vessels had an accident declaring it a total loss. A new vessel was bought by the fisherman and the REM system was transferred to this vessel in 2015. Another vessel also had to be replaced, due to serious technical failure of the engine, and again the REM system was transferred to the new ship. Final adaptations to make the REM system functioning were made early 2016. A more in-depth description of the project progress, in particular with regard to the internal and external factors impacting the project, can be found in Annex V.

\subsubsection{External factors influencing the project}

In February 2014, additional permissions for pulse fisheries to fish for sole (https://zoek.officielebekendmakingen.nl/dossier/32201/kst-32201-69.html) resulted in a short supply of sole quota for most of the participating fishermen. Subsequently the prices to rent quotas increased and the fishing activities of the fishermen of the project were impaired, as they could not fish for sole as they used to do.

\subsubsection{Science quota}

After consultation with the Ministry of Economic Affairs (EZ), the Kenniskring Staandwant visserij, the $\mathrm{NL}$ Vissersbond and VisNed, the participating fishermen applied at the Ministry for a so-called science quota for sole. Fishermen were supported during the application process by the project team (MS\&C). Both 2014 and 2015 a science quota was granted to the fishermen. At the end of 2015, science quota for 2016 was applied for taking a similar approach as in 2014 and 2015. Quota is proportional to the hours related to the project made by the fishermen. The four new fishermen selected in 2015 were not able to use al granted science quota in 2015, but did make hours related to the project. Due to a misunderstanding extra science quota applied for the four new fishermen was not granted. The extra science quota for the new fishermen was budgeted for the hours involved with the installation of the REM system on board. Several fishermen made substantial more hours for the project than originally estimated due to a large fishing effort and due to re-installation of the system on a new vessel. 


\subsubsection{Monitoring coverage}

The first REM systems were up and running in June 2013 and collected data until March 2017. Not all of the days that the REM systems were on-board of the participating vessels could be analysed. The reasons for this were primarily due to technical problems of the system (e.g. camera failures, missing data) and insufficient video quality (e.g. light conditions, area of net not visible, heavy rain). Also there was a cut-off point to the number of REM days that could be analysed within the time frame and funding of the project. When deciding on what days to include in the analyses we prioritised the selection of those fishing days that had suitable footage and that would be most representative of the overall fishing effort in terms of season, area or fishing vessel.

In the following result section "fishing days of the sampled fleet" or "monitored fishing days" only refers to those days which were analysed through the REM video analyses (and not the overall fishing effort of the sampled fleet).

Figure 5 shows the number of fishing days of the complete fleet as well as the sampled section consisting of all fishing days of the sampled fleet that were analysed. The \% of monitored fishing days analysed increased after the initial problems in 2013 and 2014 were addressed and then tapered off in 2017 towards the end of the data collection when investment in any high cost maintenance activity was stopped.

During the study period the sampling coverage of the total fishing effort was $11.07 \%$ (900 REM analysed fishing days of 8133 of the complete fleet fishing days). For single-walled gillnets (GNS) it was $9.80 \%$ (760 REM analysed fishing days of 7756 of the complete fleet fishing days) and for trammel nets (GTR) it was $37.14 \%$ (140 REM analysed fishing days of 377 of the complete fleet fishing days).

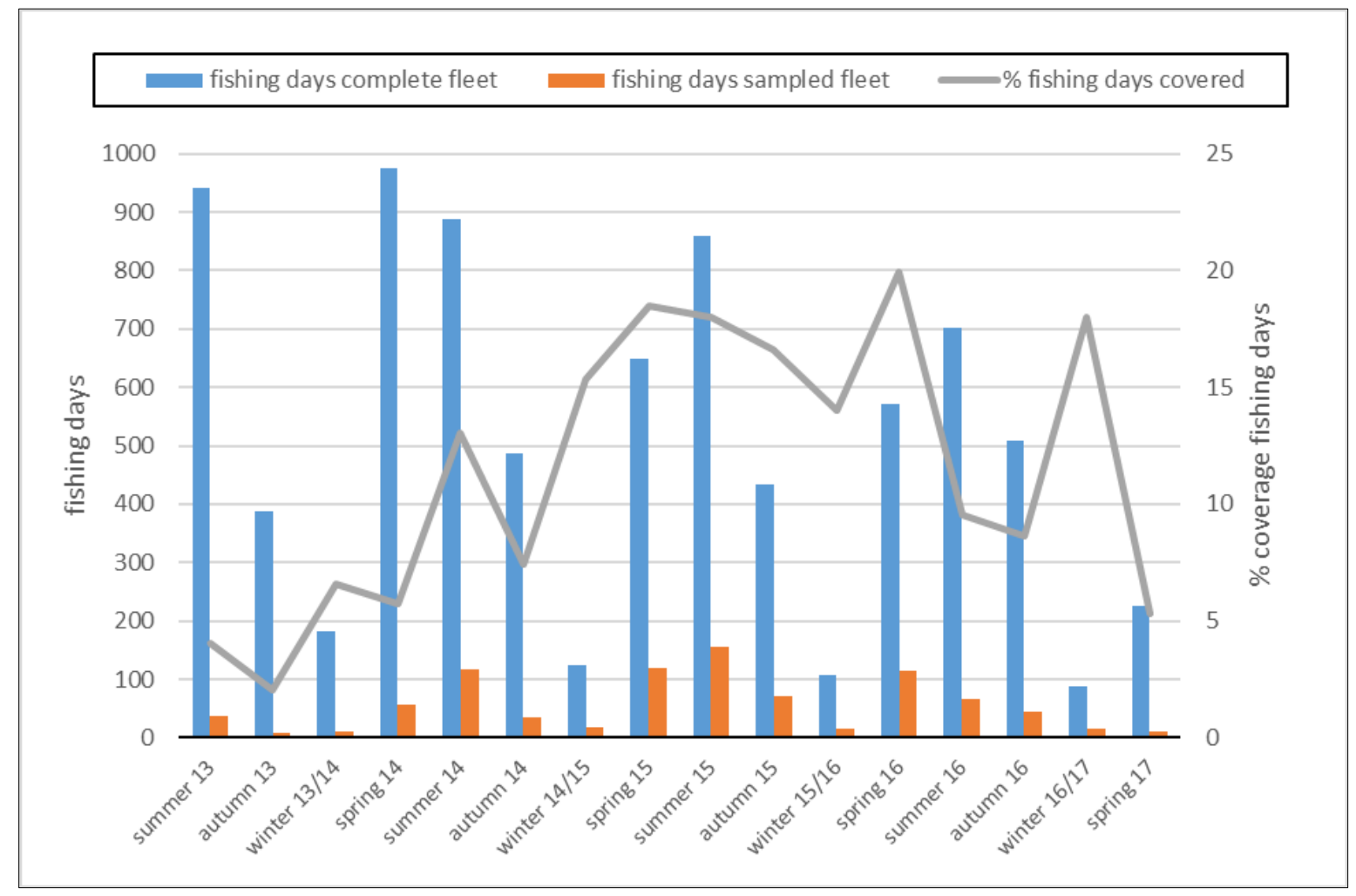

Figure 5. Fishing effort expressed as fishing days per season for the complete Dutch commercial gillnet fleet (blue) and the analysed fishing days of all participating vessels (orange) from June 2013 to March 2017. The \% of fishing days analysed per season is shown as a grey line. Seasons are defined as spring [March, April, May], summer [June, July, August], autumn [September, October, November] and winter [December, January, February]. Note that in spring 2017 only the month of March was monitored. 


\subsubsection{Fishing vessel length}

The gillnet fishery of the Dutch fleet is conducted by a high variety of vessel types, ranging in length from $2.5 \mathrm{~m}$ to more than $25 \mathrm{~m}$. One vessel is registered with a length of $35 \mathrm{~m}$, but actually is a former freighter that was converted to a houseboat and now serves as a base for fishing operations with rubber boats in the Wadden Sea. It's length was adapted in the database to the rubber boat length $(3.5 \mathrm{~m})$, to reflect the size of the vessel actually fishing.

The length of fishing vessels that were part of the sample fleet ranged in length from $5.46 \mathrm{~m}$ to $14.54 \mathrm{~m}$. Figure 6 shows that the sampled fleet encompasses the most active vessels (in terms of fishing days) of the Dutch commercial gillnet fleet during the study period (figure 6).

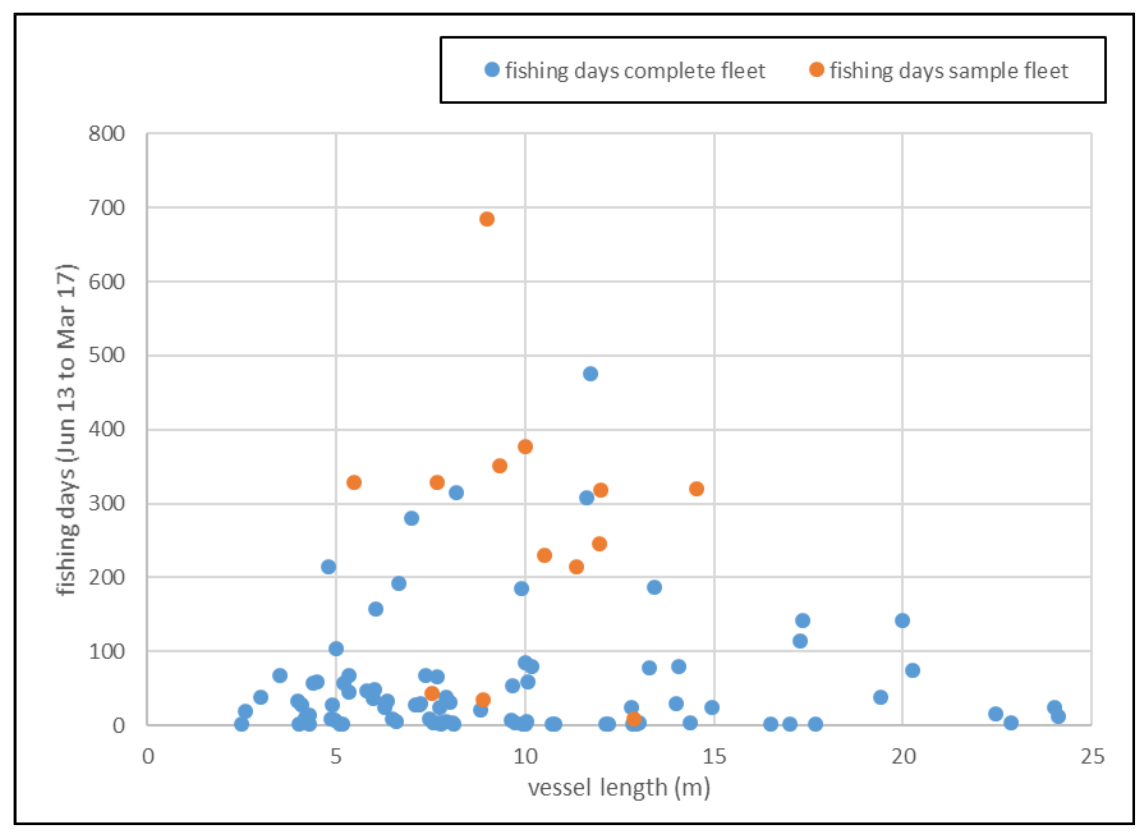

Figure 6. Fishing days fished during the study period (1. June 2013 to 31. March 2017) in relation to vessel length. Number of fishing days reflects all fishing activity expressed as fishing days of all vessels active during this time. Vessels participating in the REM study are shown in orange. 


\subsubsection{Fishing effort per net type}

As described in the methods section we used the two fishing gear types "single-walled gillnets" (GNS) and "trammel nets" (GTR) during our analyses.

Figure 7a shows all fishing vessels using single-walled gillnets during the study period on a monthly basis, as well as the number of fishing days that were analysed through REM from the sample fleet. A $\%$ of coverage is also provided. In figure $7 \mathrm{~b}$ the same is shown for trammel nets.

There is a distinct seasonal difference between the two types of fisheries. Single-walled gillnet fishery is primarily using sole nets and is done in the spring and summer. Trammel net fishery is primarily conducted in the winter and spring months. There is also a large difference between the scale of these two fisheries, with current fishing effort using trammel nets being more than 10x less than gillnets.

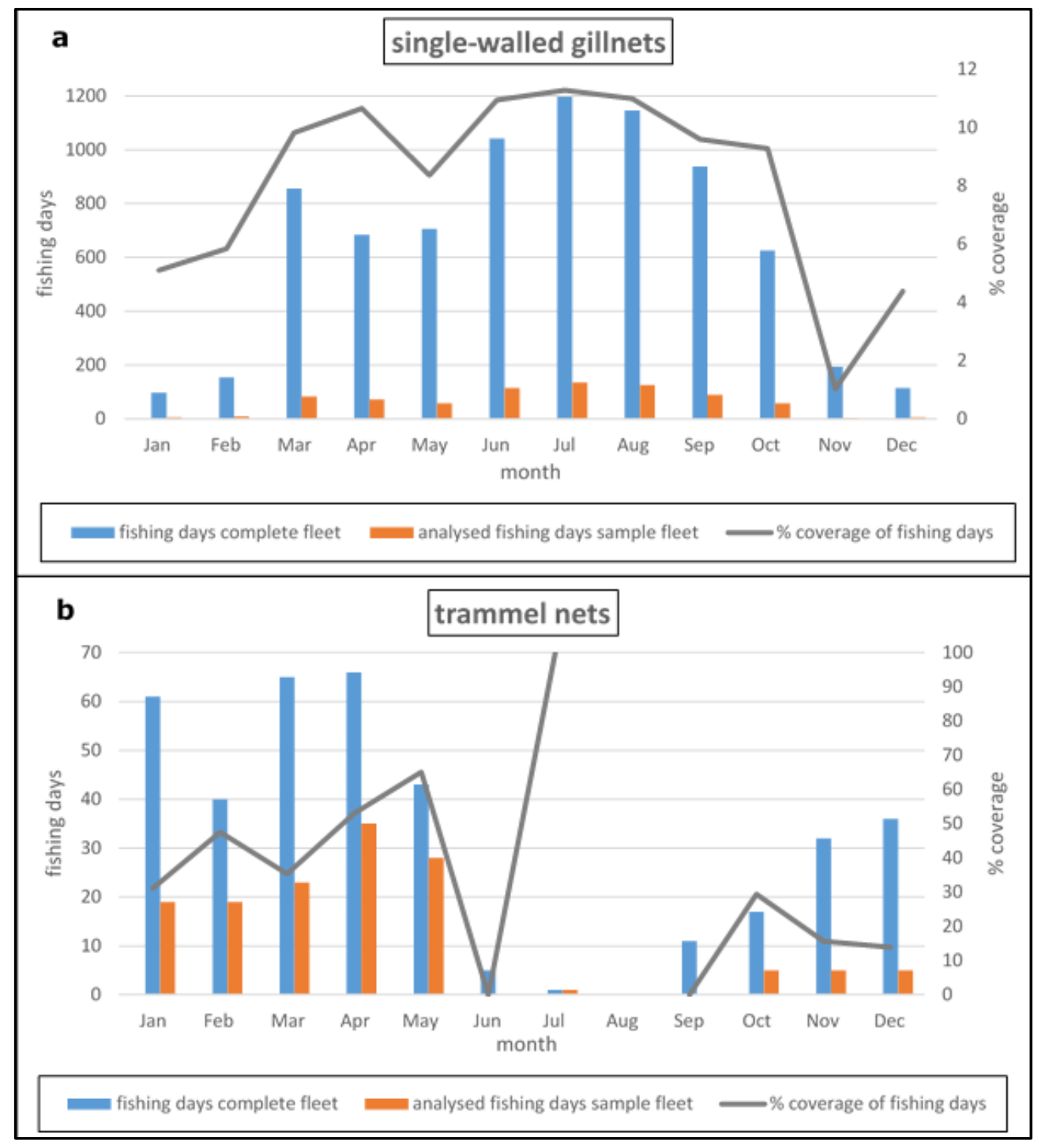

Figure 7a and b. Monthly fishing effort expressed as fishing days for the complete fishing fleet, for both single-walled and trammel nets. Analysed fishing days of the sample fleet are shown, as well as the \% of coverage. The data encompasses the period from June 2013 to March 2017. Note the different scale on the $y$ axis of both graphs. 


\subsubsection{Spatial coverage sample fishery}

The fishery effort during our study period was focussed mainly in the coastal areas of the Netherlands. The single-walled fishery also took place at a lower effort in offshore areas, including UK, German and Belgium waters (figure 8).

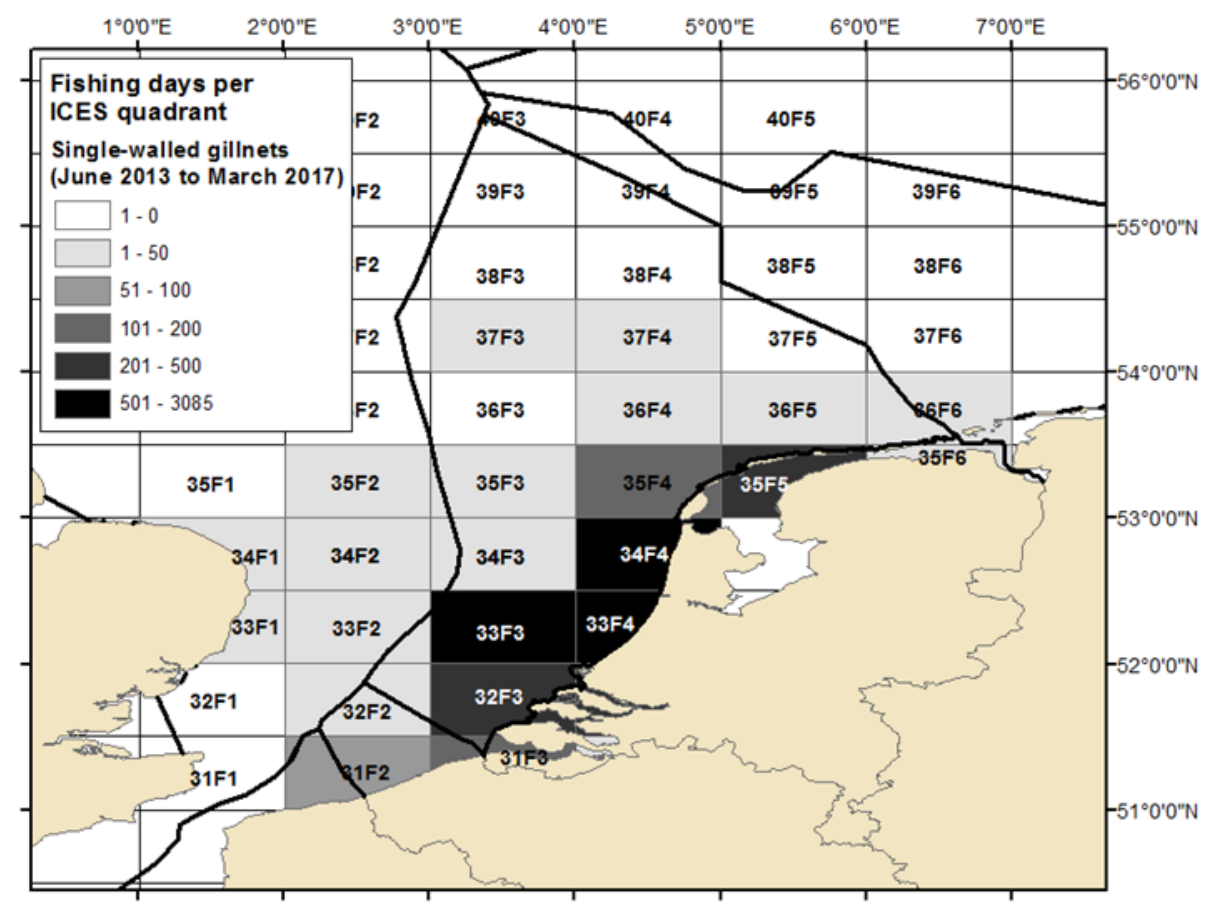

Figure 8. Fishing effort using single-walled gillnets of the Dutch gillnet fleet over the study period (June 2013 to March 2017) represented as fishing days per ICES quadrant.

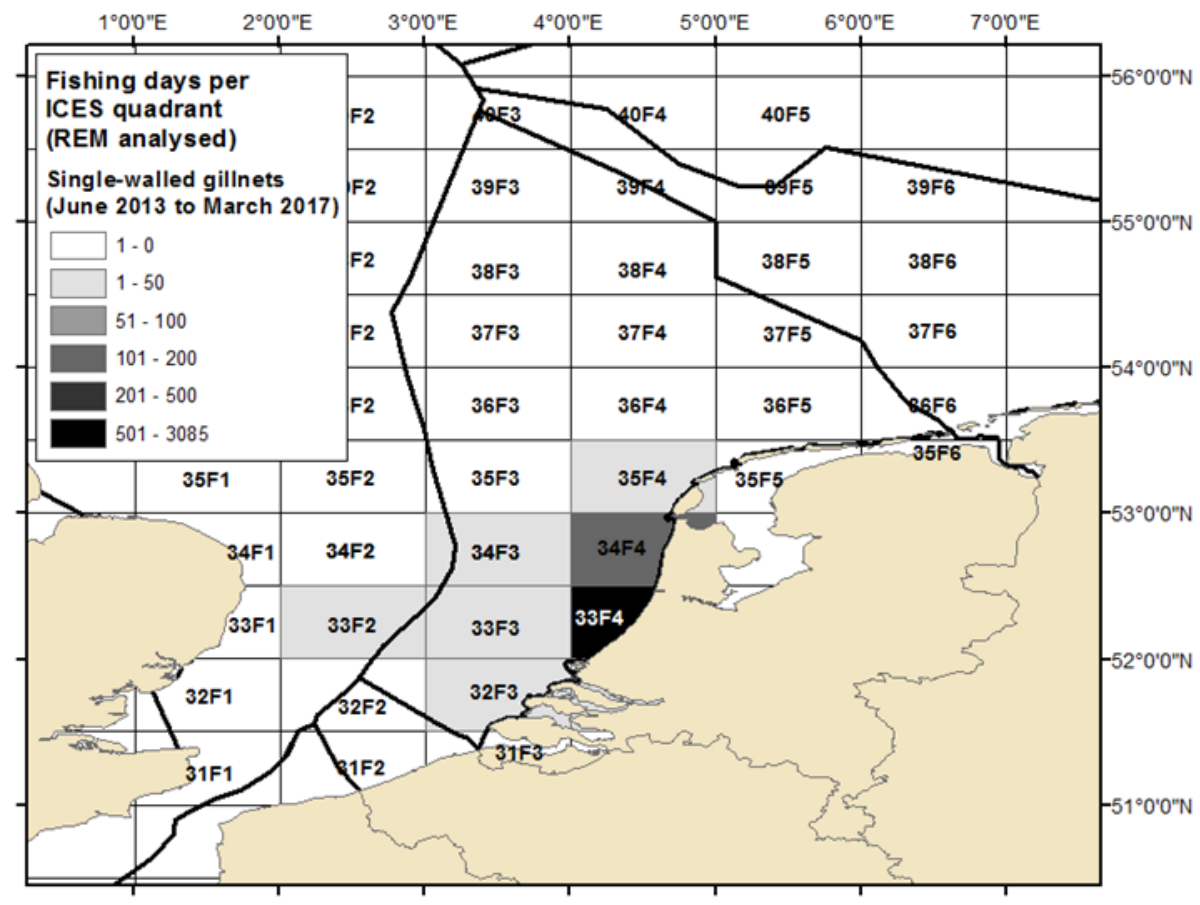

Figure 9. Fishing effort using single-walled gillnets of all analysed REM days of the Dutch gillnet fleet over the study period (1. June 2013 to 31. March 2017) represented as fishing days per ICES quadrant. 
The fishing days using single-walled gillnets that were analysed with REM covered primarily the coastal areas (ICES squares 34F4 and 33F4) (figure 9).

The trammel net fishery in Dutch waters primarily took place in a very localised coastal area (figure 10). Effort in ICES quadrants outside of 33F4 is less than 50 fishing days for the study period of 46 months. All analysed fishing days were from this region (figure 11).

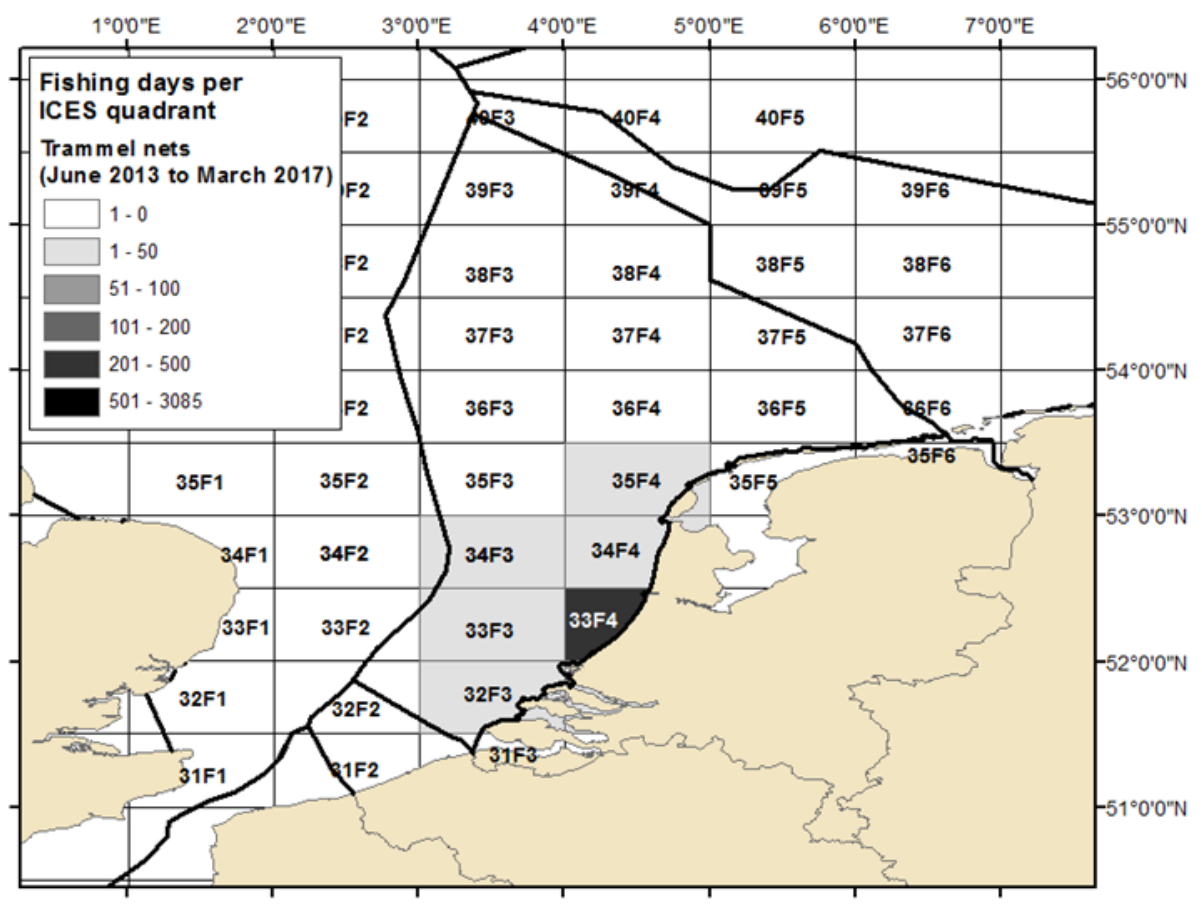

Figure 10. Fishing effort using trammel nets of the Dutch gillnet fleet over the study period (June 2013 to March 2017) represented as fishing days per ICES quadrant.

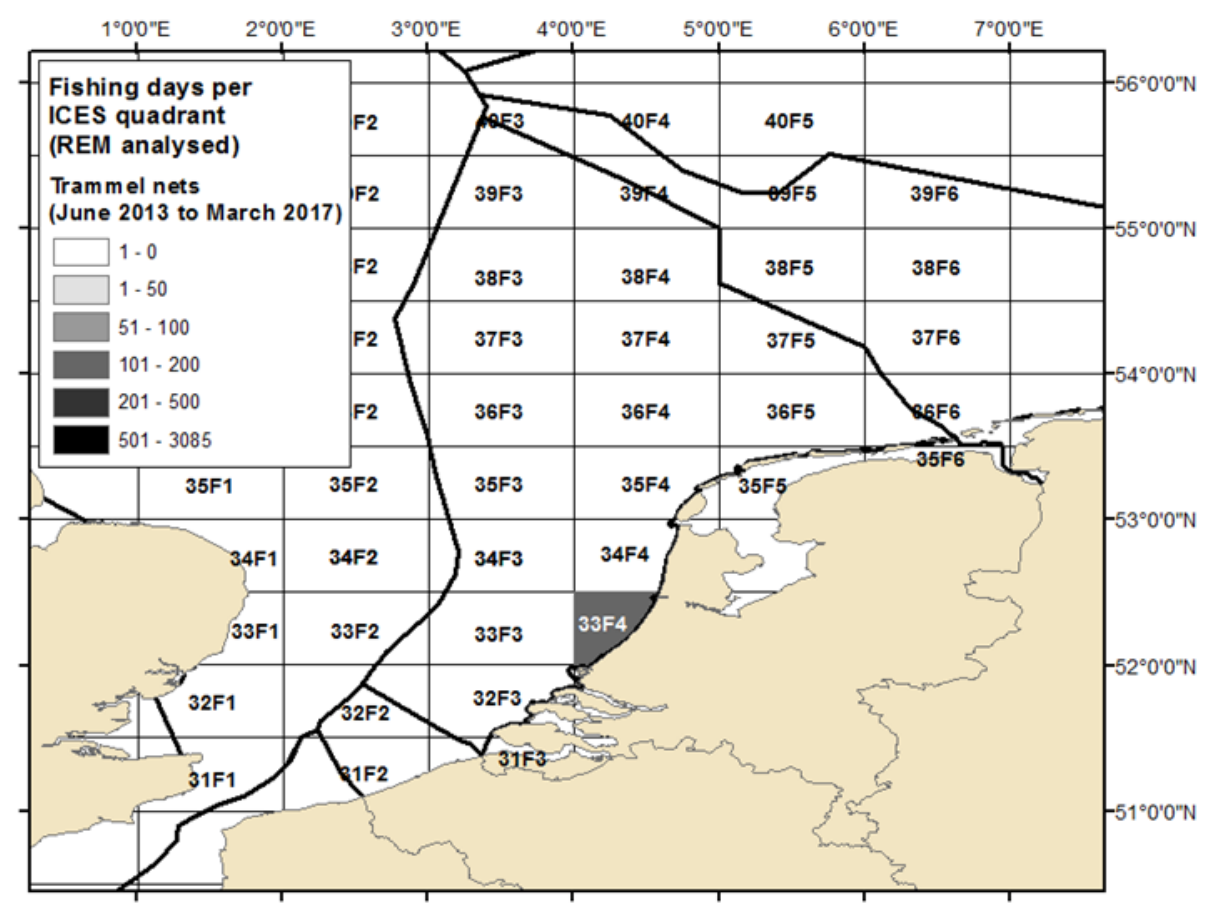

Figure 11. Fishing effort using trammel nets of all analysed REM days of the Dutch gillnet fleet over the study period (June 2013 to March 2017) represented as fishing days per ICES quadrant.

A more detailed overview and comparison of the statistics of the overall fleet and the sample fleet fishing activities in the course of the study period are provided in Annex II. 


\subsection{Bycaught harbour porpoises}

\subsubsection{Overview of registered porpoises in nets}

A total of 14 porpoises were registered as bycatches (table 1). 13 porpoises were registered during and one additional animal outside the official data collection period of the project. For all fishing days that were REM analysed, a total of 6 porpoises were registered by either the fisherman or the REM video analyses, or both. One of these bycatches was noted by the fisherman, but missed during the REM analyses, and another was missed by the fisherman (because it fell out of the net) but seen during the REM video analyses. An additional porpoise was missed by both fisherman and seen at the second viewing of all bycatch events. This animal fell out of the net before the net was hauled on board.

Table 1. Overview of all harbour porpoise bycatches registered (including one outside the REM period). REM registered: animals that were noted during the video analyses. Fisherman registered: all animals registered by fishermen.

\begin{tabular}{|c|c|c|c|c|c|}
\hline \multirow{2}{*}{ Date } & \multirow{2}{*}{$\begin{array}{c}\text { Code } \\
\text { fishing } \\
\text { vessel }\end{array}$} & registered by & \multirow{2}{*}{ Net type } & \multirow{2}{*}{$\begin{array}{c}\text { Necropsy } \\
\text { yes/no }\end{array}$} & \multirow{2}{*}{ Comments } \\
\hline & & REM Fisher & & & \\
\hline
\end{tabular}

Bycatches within REM analysed days

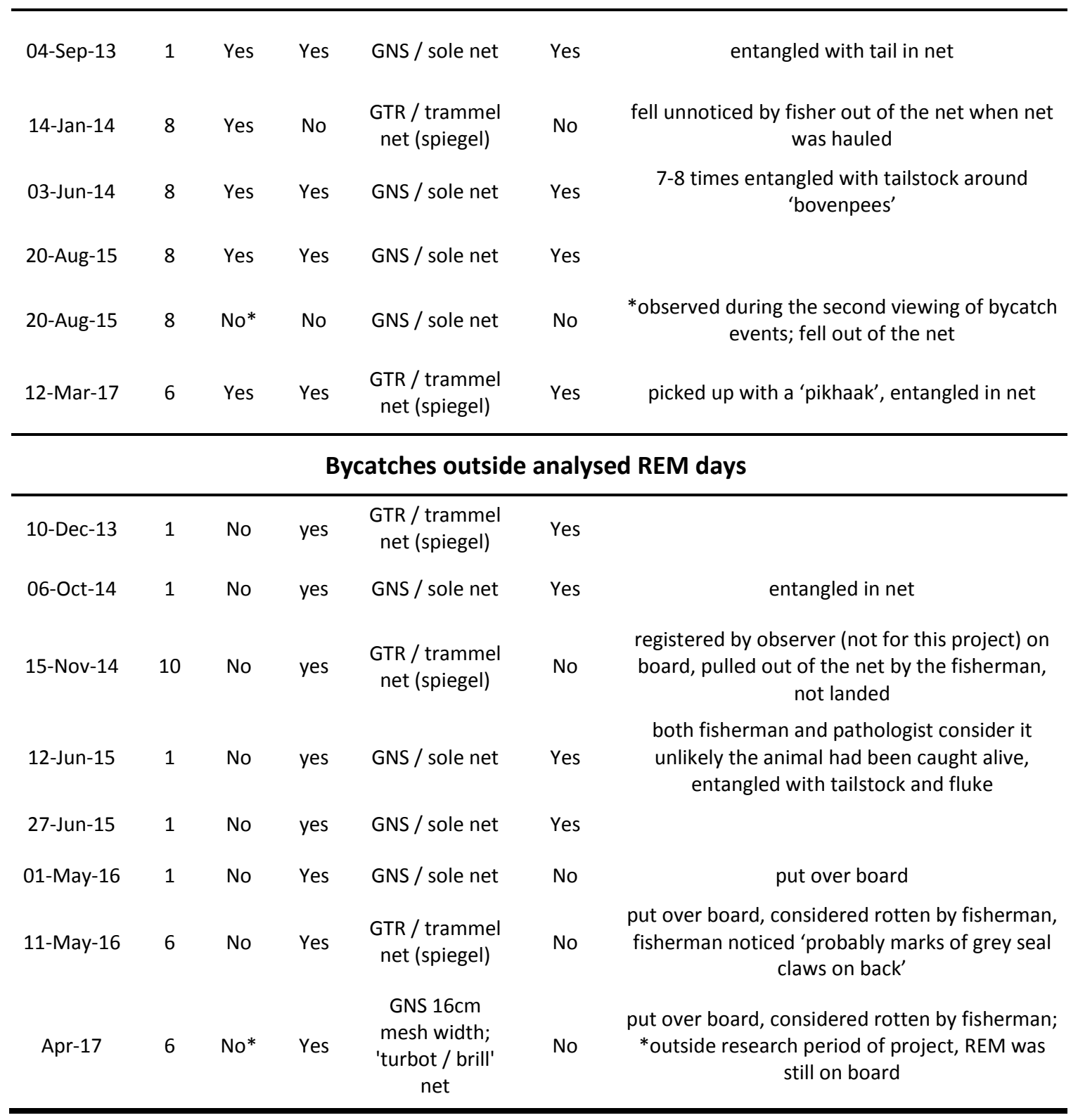


The fishermen registered 7 animals as bycaught when the REM was either not running, not installed or for REM days that were not analysed.

A total of 8 porpoises were brought ashore and all of these were necropsied. One of these was considered a post-mortem bycatch. An overview of the necropsy results can be found in Annex IV. The 6 porpoises that were registered by either the fisherman or the REM video analyses, or both, consisted of 2 animals that fell out of the net, and 4 animals that were set overboard. None of the animals that were set overboard were equipped with a label. Two animals were not tagged was because they were considered rotten and for the remaining two animals the labelling was forgotten during the fishing operation.

\subsubsection{Positions of bycaught porpoises}

Figure 12 shows the position of all bycatch events (including one with two animals). The majority of bycatches occurred within $5 \mathrm{~km}$ of the coastline. The porpoise bycatch from April 2017 was registered after the data collection had stopped and the actual date and position of bycatch is not known other than April 2017 and coastal area of Scheveningen. Details on the bycatch events can be found in table 1 , details on the pathological exams and results can be found in Annex IV.

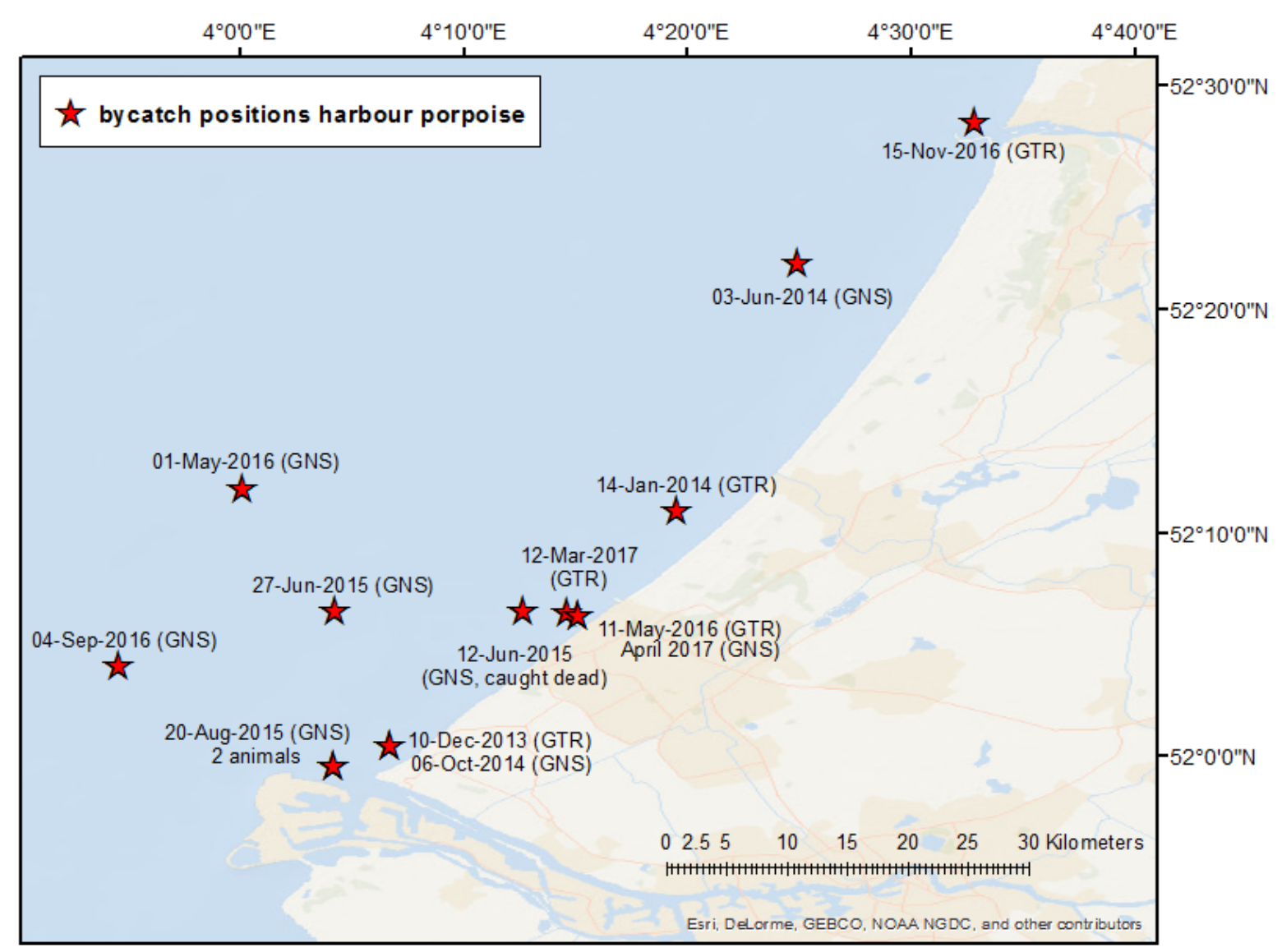

Figure 12. Positions of all porpoise bycatches registered from June 2013 to April 2017. The net types are GNS = single-walled gillnet and GTR = trammel net. In two positions animals were caught on two different occasions. On one occasion two animals were caught in one net. 


\subsection{Fishing effort}

Over the study period from 1. June 2013 to 31 . March 2017 a total of 8133 fishing days were registered in the database for the Dutch bottom-set gillnet fishery. Figure 13 shows fishing effort of the complete fleet per month for all years. As expected the highest effort was in the spring and summer, and the lowest in late autumn and winter.

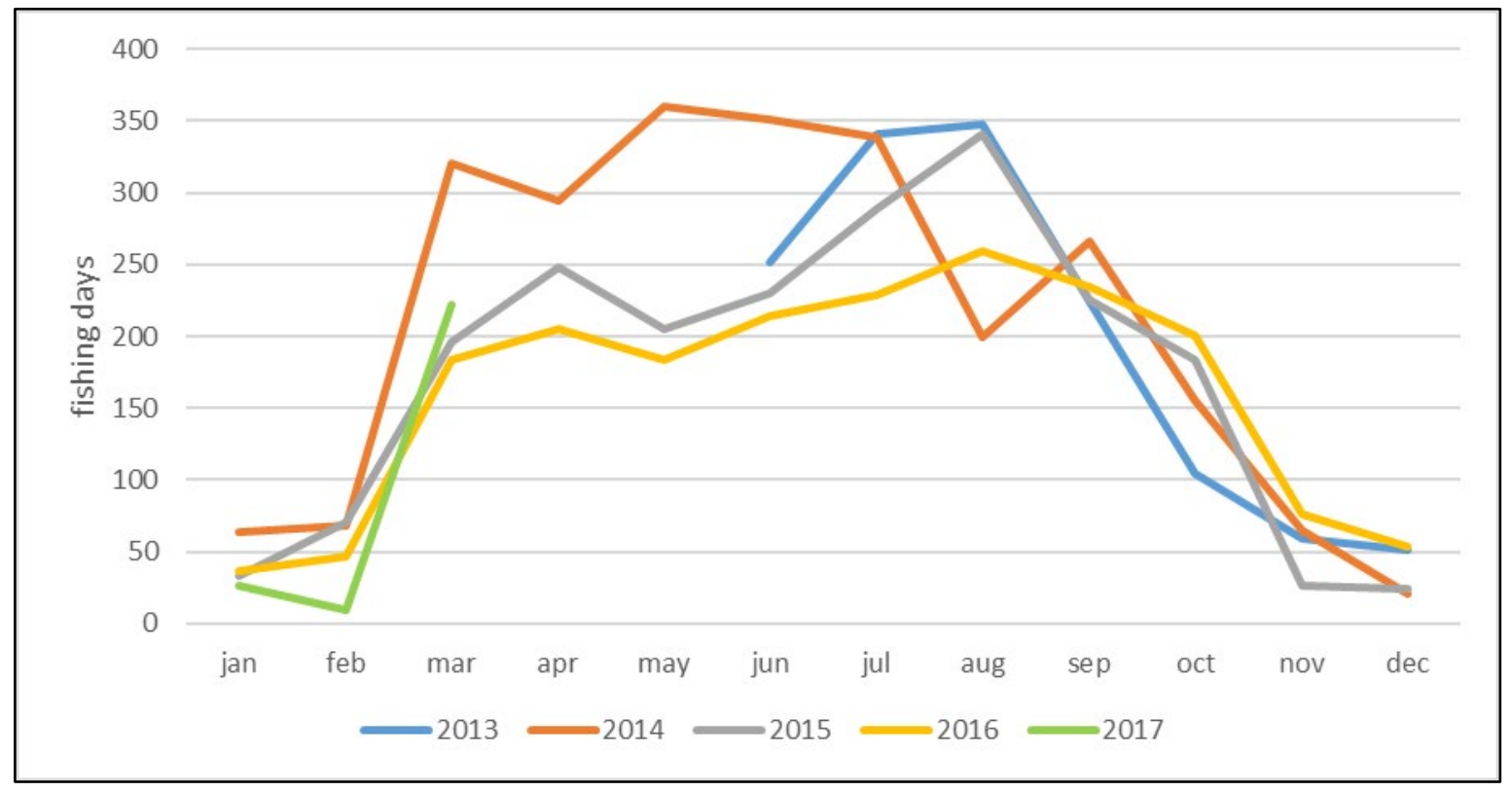

Figure 13. Effort of the complete Dutch commercial gillnet fleet from 1. June 2013 to 31. March 2017.

From 2013 to 2016 a general reduction in landed catches (ton fish per fishing day) occurred, in particular in spring and summer (figure 14).

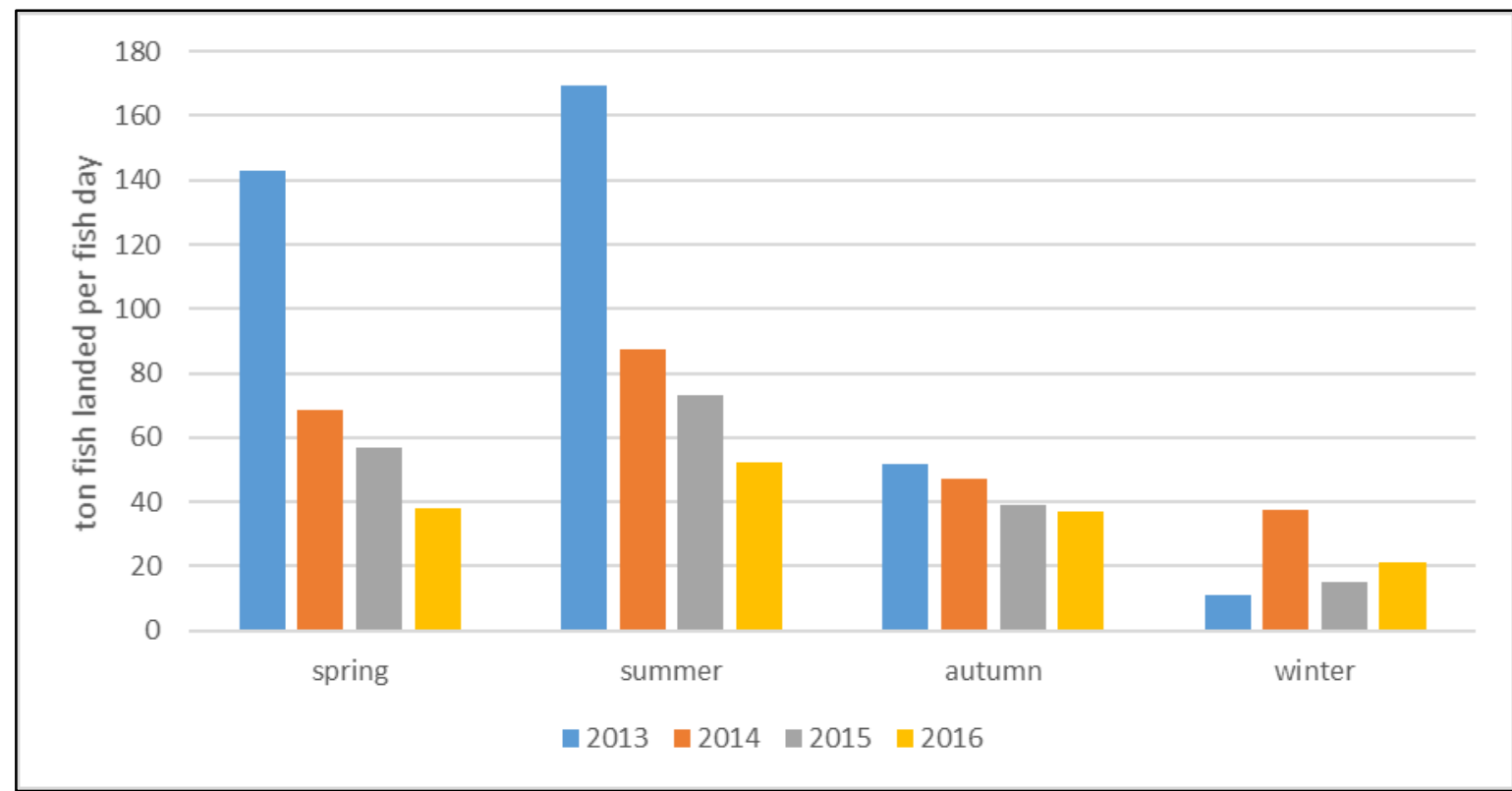

Figure 14. Ton fish landed per year and season for the Dutch commercial gillnet fishery. Seasons are defined as spring [March, April, May], summer [June, July, August], autumn [September, October, November] and winter [December, January, February]. Note that the winter season includes January and February of the following year. 


\subsection{Correction factors}

\subsubsection{Video quality}

During the REM analysis the video quality was recorded as video completeness and the chance for the observer to detect a bycatch (how "usable" is the video to detect bycaught porpoises). For the 900 fishing days that were analysed the average video completeness was $96.52 \%$ and on average $79.09 \%$ of the video footage was considered usable for REM analysis. The combined overall video quality (video completeness $x$ usable video) was applied per fishing day to obtain a value of corrected fishing day. This was on average $76.45 \%$ of each fishing day for all data points. Average video quality was similar between the seasons with average video quality values of $77.4 \%$ for spring, $76.6 \%$ for summer, $74.3 \%$ for autumn and $76.4 \%$ for winter (figure 15 ).

The video quality values were calculated as average per fishing day and applied to the monitored fishing day to adjust the actual effort of the REM analyses. For example, if the video quality for a fishing day was $80 \%$, this resulted in an actual fishing day of 0.8 (because $20 \%$ of the footage could not be analysed sufficiently).

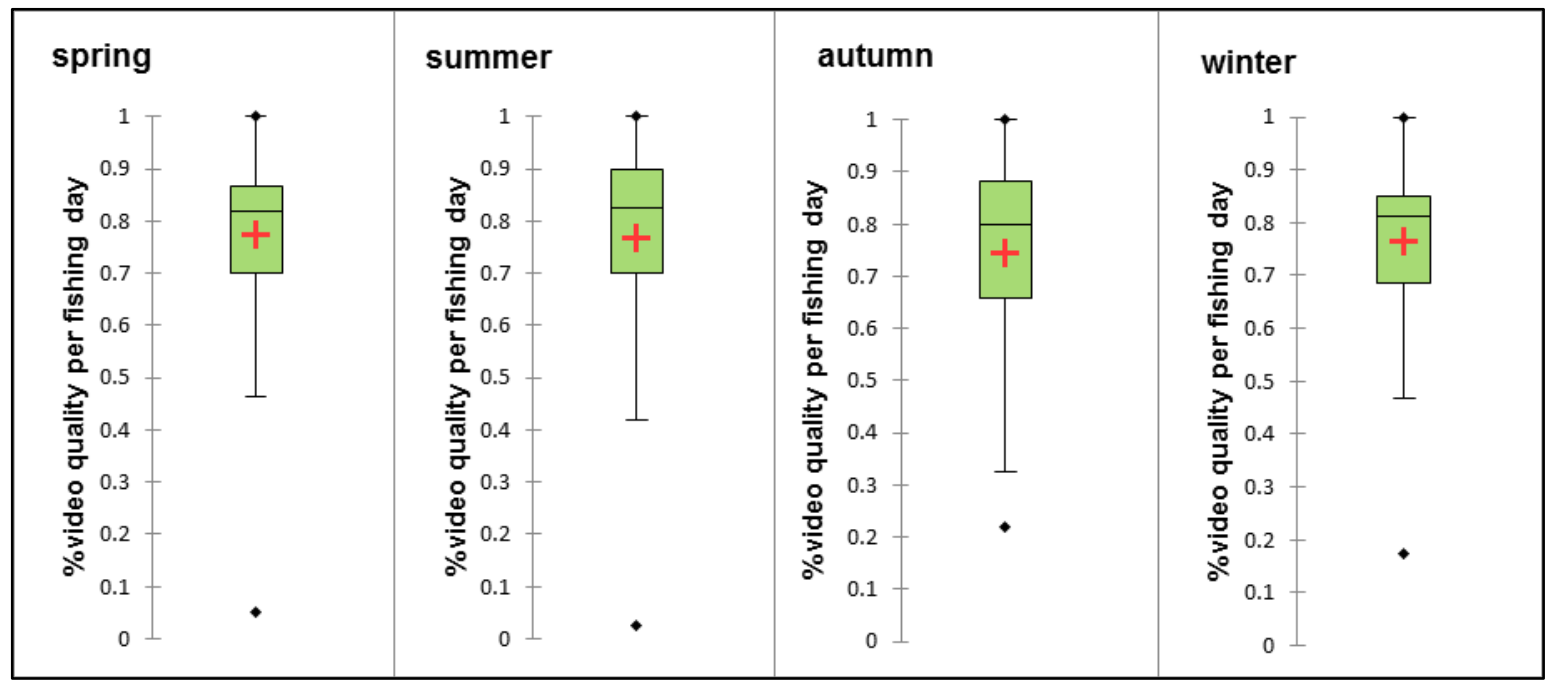

Figure 15. Video quality (video completeness $x$ usable video) per analysed fishing day for spring (March, April, May), summer (June, July, August), autumn (September, October, November), winter (December, January, February). The red cross marks the mean.

\subsubsection{Missed animals}

From the total of 900 fishing days that had an active REM system a sub-sample of 87 days (9.7\%) was viewed by an independent observer team at a slower video speed to obtain a correction factor (see methods section). In this sub-sample not new bycatches were found.

To cross-check the performance of the independent observer team, the five days with known bycatch events were added to this dataset. All of these bycatches were seen by the observers. However, during the bycatch event from the $20^{\text {th }}$ August 2015 (see table 1) an additional animal was registered. Apparently two animals had been caught in close vicinity to each other in the same net. While the fisher was busy to secure the first bycatch on board, the second animal most likely fell out of the net (figure 16). This animal was noted by the independent observer team. It was drifting quickly away from the net and had not been seen during the first REM analyses.

Because of the extremely low number of bycatches registered it was decided that it was not possible to derive a specific correction factor for observer error from this data set. The additional animal spotted during the independent checking of the data was added to the overall number of registered bycatches. 
On the two occasions were porpoises feel out of the net when REM was active, they were not seen by the fishermen. Again, the low number of overall bycatch events did not allow a reliable calculation of the how often this occurred. This issue is considered further in the discussion chapter.

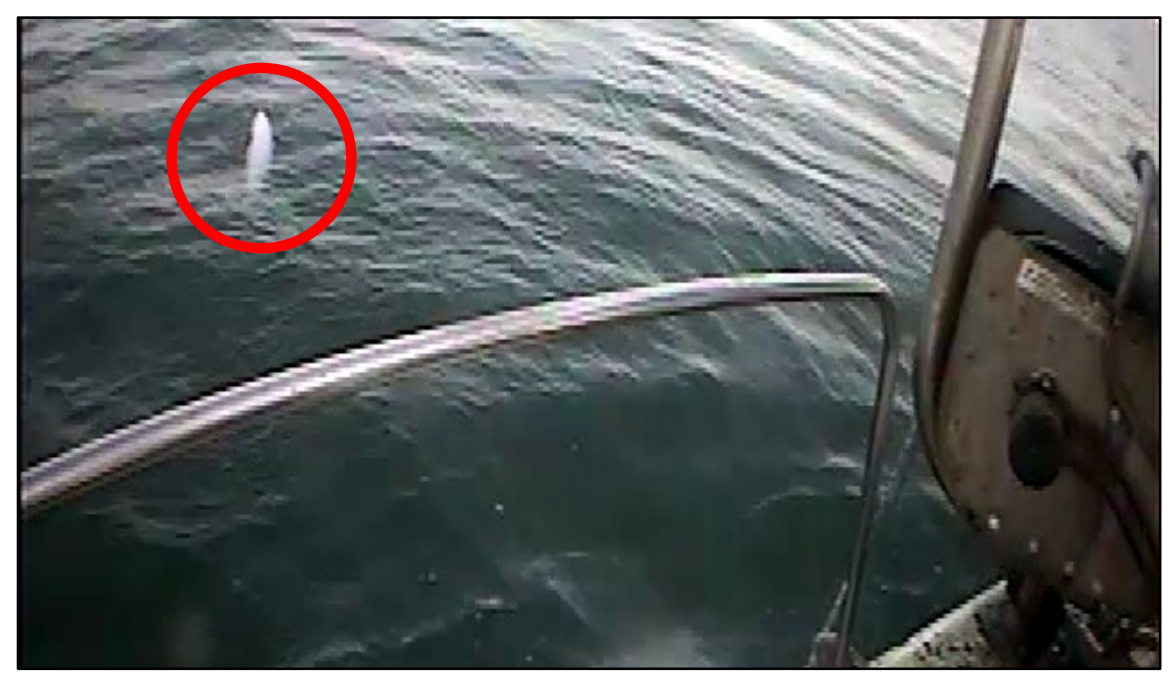

Figure 16. Harbour porpoise seen drifting at sea (red circle), assumed to have fallen out of the net. During this bycatch event two animals were bycaught in the same net and in close vicinity to each other. (source: REM footage this project)

\subsection{Bycatch estimates}

\subsection{1 calculation of bycatch rates}

Bycatch rates (applying corrected video effort per fishing day and corrected bycatch numbers) were calculated for all REM analysed days for the three effort types. The bycatch rates were calculated for all net types combined, as well as separately for single-walled gillnets and trammel nets. Table 2 provides an overview of the results for all net types combined.

Table 2. Bycatch rates for harbour porpoises in the Dutch commercial bottom-set gillnet fishery (1. June 2013 to 31. March 2017). Three different types of effort values are applied. Confidence intervals and coefficient of variation are calculated using non-parametric bootstrapping.

\begin{tabular}{cccc} 
All net types & \multicolumn{3}{c}{ effort type } \\
(GNS and GTR) & fishing day & ton landed & net length (km) \\
\cline { 2 - 4 } effort REM fleet & 900 & 106 & 9503 \\
Corrected effort for video quality & 688 & 88 & 7919 \\
Registered bycatches & 6 & 6 & 6 \\
Average bycatch rate & $\mathbf{0 . 0 0 8 7}$ & $\mathbf{0 . 1 1 4 5}$ & $\mathbf{0 . 0 0 1 1}$ \\
C.I. low & 0.0006 & 0.0000 & 0.0001 \\
C.I. high & 0.0169 & 0.2571 & 0.0021 \\
\hline
\end{tabular}

Bycatch rates were also calculated separately for single-walled gillnet and trammel net fishery. The bycatch rates are noticeably higher for the trammel fishery than for the single-walled gillnet (table 3 and 4). The trammel net rate bycatch was 2.6 times higher for the unit "fishing days", 1.5 times higher when using "ton landed" and 7.2 times higher when using "net length". 
Table 3. Bycatch rates for harbour porpoise in the Dutch commercial bottom-set gillnet fishery (1. June 2013 to 31. March 2017) for single-walled gillnets (GNS). Three different types of effort values are applied. Confidence intervals are calculated using non-parametric bootstrapping.

\begin{tabular}{cccc}
\hline Single-walled gillnets & \multicolumn{3}{c}{ effort type } \\
\cline { 2 - 4 } (GNS) & fishing day & ton landed & net length (km) \\
\hline effort REM fleet & 760 & 87 & 9140 \\
Corrected effort for video quality & 588 & 66 & 7616 \\
Registered bycatches & 4 & 4 & 4 \\
bycatch rate & $\mathbf{0 . 0 0 7 0}$ & $\mathbf{0 . 1 0 6 8}$ & $\mathbf{0 . 0 0 0 6}$ \\
C.I. low & 0 & 0 & 0 \\
C.I. high & 0.0156 & 0.2697 & 0.0013 \\
\hline
\end{tabular}

Table 4. Bycatch rates for harbour porpoise in the Dutch commercial bottom-set gillnet fishery (1. June 2013 to 31. March 2017) for trammel nets (GTR). Three different types of effort values are applied. Confidence intervals are calculated using non-parametric bootstrapping.

\begin{tabular}{cccc}
\hline Trammel nets & \multicolumn{3}{c}{ effort type } \\
\cline { 2 - 4 } (GTR) & fishing day & ton landed & net length (km) \\
\hline effort REM fleet & 140 & 19 & 363 \\
Corrected effort for video quality & 100 & 14 & 303 \\
Registered bycatches & 2 & 2 & 2 \\
bycatch rate & $\mathbf{0 . 0 1 8 1}$ & $\mathbf{0 . 1 5 6 2}$ & $\mathbf{0 . 0 0 4 0}$ \\
C.I. low & 0 & 0 & 0 \\
C.I. high & 0.0426 & 0.4129 & 0.0095 \\
\hline
\end{tabular}

\subsubsection{Bycatch numbers}

The bycatch rates (and their corresponding lower and upper 95\% confidence limits of the rates) were multiplied by the overall fishing effort (for each of the three categories) for the complete Dutch commercial gillnet fleet during the study period to obtain estimates of number of bycaught animals.

The resulting bycatch numbers for all net types combined are provided in table 5 . In total, the extrapolation of the overall bycatch rate results in an estimated 71 (using "fishing days"), 109 (using "ton fish landed") and 98 (using "net length") bycaught porpoises for the study period. This translates to an annual average of between 19 and 26 animals being bycaught in the Dutch commercial gillnet fleet (table 5).

We also applied the overall bycatch rate to the effort of the fishing fleet in the years 2014, 2015 and 2016, as these were years that were fully monitored (table 6). As the extrapolated numbers are directly dependant on the effort, and the fishing effort of this fleet declined over the last year, the estimated bycatches for all three effort types also decline from 2014 to 2016 . Annual bycatch numbers vary between years and effort types used and resulted in values between 17 and 36 animals. 
Table 5. Estimated bycatch numbers for harbour porpoise in the Dutch commercial bottom-set gillnet fishery for the study period (1. June 2013 to 31. March 2017). Monthly averages are based on the 46 months analysed, the annual average is a multiplication of the monthly average by twelve. Note that estimated total porpoise bycatch has been calculated using unrounded figures for bycatch rate.

\section{June 2013 to 31 . March 2017 all net types combined}

\begin{tabular}{|c|c|c|c|c|}
\hline Effort type & $\begin{array}{c}\text { Effort } x \text { Bycatch } \\
\text { rate }\end{array}$ & $\begin{array}{l}\text { Bycatch estimate } \\
\text { study period } \\
(95 \% \text { C.I. })\end{array}$ & $\begin{array}{c}\text { Bycatch estimate } \\
\text { monthly average } \\
(95 \% \text { C.I.) }\end{array}$ & $\begin{array}{c}\text { Bycatch estimate } \\
\text { annual average } \\
\text { ( } 95 \% \text { C.I.) }\end{array}$ \\
\hline Fish days & $8133 \times 0.0087$ & $\begin{array}{c}\mathbf{7 1} \\
(95 \% \text { C.I. } 5-137)\end{array}$ & $\begin{array}{c}1.5 \\
(95 \% \text { C.I. } 0-3)\end{array}$ & $\begin{array}{c}19 \\
(95 \% \text { C.I. } 1-36)\end{array}$ \\
\hline $\begin{array}{l}\text { Ton fish } \\
\text { landed }\end{array}$ & $949 \times 0.1011$ & $\begin{array}{c}109 \\
(95 \% \text { C.I. } 0-244)\end{array}$ & $\begin{array}{c}2.4 \\
(95 \% \text { C.I. } 0-5)\end{array}$ & $\begin{array}{c}\mathbf{2 8} \\
(95 \% \text { C.I. } 0-64)\end{array}$ \\
\hline $\begin{array}{l}\text { Km net } \\
\text { length }\end{array}$ & $949 \times 0.1145$ & $\begin{array}{c}\mathbf{8 8} \\
(95 \% \text { C.I. } 6-170)\end{array}$ & $\begin{array}{c}1.9 \\
(95 \% \text { C.I. } 0-4)\end{array}$ & $\begin{array}{c}\mathbf{2 3} \\
(95 \% \text { C.I. } 2-44)\end{array}$ \\
\hline
\end{tabular}

Table 6. Bycatch numbers for the years 2014, 2015 and 2016 for all three fishing effort types. The bycatch rate used is based on both single-walled gillnet and trammel net gears combined and was calculated for the complete study period (June 2013 to March 2017). Note that estimated total porpoise bycatch has been calculated using unrounded figures for bycatch rate.

\begin{tabular}{|c|c|c|c|c|c|c|}
\hline & $\begin{array}{l}\text { Effort } \mathrm{x} \\
\text { bycatch rate }\end{array}$ & $\begin{array}{l}\text { Bycatch } \\
\text { estimate }\end{array}$ & $\begin{array}{l}\text { Effort } x \\
\text { bycatch rate }\end{array}$ & $\begin{array}{l}\text { Bycatch } \\
\text { estimate }\end{array}$ & $\begin{array}{l}\text { Effort } x \\
\text { bycatch rate }\end{array}$ & $\begin{array}{l}\text { Bycatch } \\
\text { estimate }\end{array}$ \\
\hline Fish days & $\begin{array}{l}2503 x \\
0.0070\end{array}$ & 22 & $\begin{array}{l}2070 x \\
0.0087\end{array}$ & 18 & $\begin{array}{l}1921 \times \\
0.0087\end{array}$ & 17 \\
\hline $\begin{array}{l}\text { Ton fish } \\
\text { landed }\end{array}$ & $\begin{array}{l}316 \times \\
0.1068\end{array}$ & 36 & $\begin{array}{l}197 x \\
0.1145\end{array}$ & 23 & $\begin{array}{l}164 x \\
0.1145\end{array}$ & 19 \\
\hline $\begin{array}{l}\text { Km net } \\
\text { length }\end{array}$ & $\begin{array}{l}26952 x \\
0.0006\end{array}$ & 30 & $\begin{array}{l}19326 x \\
0.0011\end{array}$ & 21 & $\begin{array}{l}17324 x \\
0.0011\end{array}$ & 19 \\
\hline
\end{tabular}

To investigate the difference in catch probability between single-walled gillnets and trammel nets we also calculated gear specific bycatch rates. This was applied to the corresponding effort to obtain bycatch numbers per net type. Table 7 provides an overview of the results for single-walled gillnets. The bycatch number for the project period range from 44 to 95 depending on the effort type used. The annual average bycatch number for ranges from 12 to 25 for this fishery.

The trammel net fishery, which had a higher bycatch rate for all types of effort categories than singlewalled gillnets, has an estimated 5 to 10 animals bycaught during the study period. The annual average for trammel net fishery is 1 to 3 bycaught porpoises (table 8 ).

Even though the bycatch rate is higher for trammel nets, because of the comparatively low fishing effort in this type of fishery the actual annual bycatch numbers are lower than the ones estimated for the single-walled gillnets. 
Table 7. Estimated bycatch numbers for harbour porpoise in the Dutch commercial bottom-set gillnet fishery for the study period (June 2013 to March 2017) for single-walled gillnets (GNS), using the net specific rate. Monthly averages are based on the 46 months analysed, the annual average is calculated by multiplying the monthly average by twelve. Note that estimated total porpoise bycatch has been calculated using unrounded figures for bycatch rate.

\section{June 2013 to March 2017 single-walled gillnets}

\begin{tabular}{ccccc}
\hline Effort type & $\begin{array}{c}\text { Effort } \mathrm{x} \text { bycatch } \\
\text { rate }\end{array}$ & $\begin{array}{c}\text { bycatch number } \\
(95 \% \text { C.I. })\end{array}$ & $\begin{array}{c}\text { Monthly average } \\
(95 \% \text { C.I. })\end{array}$ & $\begin{array}{c}\text { Annual average } \\
(95 \% \text { C.I. })\end{array}$ \\
\hline Fish days & $7756 \times 0.0063$ & $\mathbf{5 5}$ & 1.2 & $\mathbf{1 4}$ \\
& & $(95 \%$ C.I. $0-121)$ & $(95 \%$ C.I. $0-3)$ & $(95 \%$ C.I. $0-32)$ \\
Ton fish landed & $888 \times 0.0838$ & $(95 \%$ C.I. $0-239)$ & $(95 \%$ C.I. $0-5)$ & $(95 \%$ C.I. $0-62)$ \\
Km net length & $79285 \times 0.0005$ & $(95 \%$ C.I. $0-103)$ & $(95 \%$ C.I. $0-2)$ & $(95 \%$ C.I. $0-27)$ \\
\hline
\end{tabular}

Table 8. Estimated bycatch numbers for harbour porpoise in the Dutch commercial bottom-set gillnet fishery for the study period (June 2013 to March 2017) for trammel nets, using the net specific rate. The bycatch numbers are estimated applying the specific rate calculated for trammel nets. Monthly averages are based on the 46 months analysed, the annual average is calculated by multiplying the monthly average by twelve. Note that estimated total porpoise bycatch has been calculated using unrounded figures for bycatch rate.

\section{June 2013 to March 2017 trammel nets}

\begin{tabular}{ccccc}
\hline Effort type & $\begin{array}{c}\text { Effort } \times \text { bycatch } \\
\text { rate }\end{array}$ & $\begin{array}{c}\text { bycatch number } \\
(95 \% \text { C.I. })\end{array}$ & $\begin{array}{c}\text { Monthly average } \\
(95 \% \text { C.I. })\end{array}$ & $\begin{array}{c}\text { Annual average } \\
(95 \% \text { C.I. })\end{array}$ \\
\hline Fish days & $377 \times 0.0181$ & $\mathbf{7}$ & 0.15 & $\mathbf{2}$ \\
& & $(95 \%$ C.I. $0-16)$ & $(95 \%$ C.I. $0-0.45)$ & $(95 \%$ C.I. $0-4)$ \\
Ton fish landed & $62 \times 0.1562$ & $\mathbf{1 0}$ & 0.21 & $\mathbf{3}$. $0-7)$ \\
Km net length & $1253 \times 0.0040$ & $(95 \%$ C.I. $0-12)$ & $(95 \%$ C.I. $0-0.33)$ & $(95 \%$ C.I. $0-3)$ \\
\hline
\end{tabular}




\subsection{Population effects}

One of the aims of this project was to assess if bycatch reduction measures need to be applied to keep the Favourable Conservation status for harbour porpoise in Dutch North Sea waters. To do this the annual bycatch estimates from the Dutch gillnet fishery were set into a context with our (national) population sizes.

Abundance estimates for the Dutch North Sea are available through dedicated aerial surveys using line-transect distance sampling conducted at different times since 2010. The estimates are provided for different years and seasons and cover the Dutch North Sea waters (table 9). The point estimates differ between seasons and years. The changes in abundance between years most likely reflect the dynamics in porpoise distribution in Dutch waters, e.g. a small shift in distribution of the North Sea population can lead to large shifts in local abundance.

Table 9. Overview of abundance estimates for harbour porpoise in the Dutch North Sea based on the results of dedicated aerial surveys. The highlighted cell shows the value used to assess bycatch mortality for this project.

\begin{tabular}{cccc}
\hline Season / year & Abundance & 95\% C.I. & reference \\
\hline Summer 2010 & 25998 & $13988-53623$ & Geelhoed et al. 2013, 2014, 2015 \\
Autumn 2010 & 29963 & $16098-59011$ & Geelhoed et al. 2013, 2014, 2015 \\
$\begin{array}{c}\text { Spring 2011 } \\
\text { Average value for one year } \\
\text { (summer 2010, autumn }\end{array}$ & 85572 & $49324-165443$ & Geelhoed et al. 2013, 2014, 2015 \\
$\begin{array}{c}\text { 2010 and spring 2011) } \\
\text { Spring 2012 }\end{array}$ & 67178 & - & Scheidat et al. 2015 \\
Spring 2013 & 63408 & $32478-128588$ & Geelhoed et al. 2013, 2014, 2015 \\
Summer 2014 & 76773 & $43414-154265$ & Geelhoed et al. 2013, 2014, 2015 \\
Summer 2015 & 41299 & $21194-79256$ & Geelhoed et al. 2013, 2014, 2015 \\
\hline
\end{tabular}

Choosing the appropriate values to estimate the impact of the Dutch commercial bottom-set gillnet fishery on the Dutch porpoise population is a challenge. Our approach was based on a pre-cautionary approach (as advised by ASCOBANS). Below we list the rationale for choosing the used values:

i. An annual population size average was only available for a time period that did not match ours (2010/11). Therefore we decided to use the lowest population estimates available during our study period (the summer of 2015) and the associated confidence interval. As population estimates vary between seasons, with the lowest values occurring in the summer months (see Geelhoed et al. 2013, 2014, 2015) this value is likely an underestimate of the average porpoise abundance in Dutch waters.

i. The bycatch numbers are estimated for the complete Dutch commercial gillnet fleet, which includes some vessels operating in non-Dutch waters (thus resulting in a higher overall fishing effort than as if one was to only use the effort in Dutch waters).

ii. Our sampling effort differed between single-walled gillnets and trammel nets. Because of the low bycatch events within the two different strata we decided to use the overall rate combining all net types. The resulting bycatch numbers are higher than they would be if applying the two bycatch rates per net type separately to their respective fishing efforts.

iii. To obtain a range of the average annual mortality the bycatch numbers all effort types were used. For an upper range of potential population impact that could be used to inform policy decisions, we applied the lower C.I. value of the population estimate with the highest available C.I. value of bycatch. 
The resulting percentage of bycatch of harbour porpoise in the Dutch commercial gillnet fleet for the Dutch porpoise population is between 0.05 and $0.07 \%$. The estimated maximum value of annual mortality for the Dutch porpoise population the Dutch commercial gillnet fleet is $0.3 \%$ (table 10 ).

Table 10. Approximation of annual porpoise mortality for the Dutch commercial bottom-set gillnet fishing fleet based. The estimations are based on abundance estimate for the summer of 2015 and the bycatch estimates (based on three different effort types). *based on the lower 95\%C.I. value of the population estimate at the higher $95 \%$ C.I. of the bycatch estimates.

\begin{tabular}{|c|c|c|c|c|}
\hline Effort type & $\begin{array}{c}\text { Dutch } \\
\text { porpoise } \\
\text { population } \\
\text { estimate }\end{array}$ & Bycatch estimates & $\begin{array}{c}\text { Annual bycatch } \\
\text { mortality }\end{array}$ & $\begin{array}{c}\text { Upper range of } \\
\text { annual bycatch } \\
\text { mortality* }\end{array}$ \\
\hline Fish days & & $\begin{array}{c}19 \\
(95 \% \text { C.I. } 1-36)\end{array}$ & $0.05 \%$ & $0.17 \%$ \\
\hline $\begin{array}{l}\text { Ton fish } \\
\text { landed }\end{array}$ & $\begin{array}{c}\mathbf{4 1 2 9 9} \\
(95 \% \text { C.I. } \\
21194-79256)\end{array}$ & $\begin{array}{c}28 \\
(95 \% \text { C.I. } 0-64)\end{array}$ & $0.07 \%$ & $0.30 \%$ \\
\hline $\begin{array}{l}\text { Km net } \\
\text { length }\end{array}$ & & $\begin{array}{c}23 \\
(95 \% \text { C.I. } 2-44)\end{array}$ & $0.06 \%$ & $0.21 \%$ \\
\hline
\end{tabular}




\section{Discussion}

\subsection{Methodological considerations}

\subsubsection{The sampled fleet}

\subsubsection{REM coverage of the fleet}

This was the first time REM was used to estimate bycatch of harbour porpoise for the complete Dutch commercial gillnet fleet. At the start of the project we aimed to have a minimum observer coverage of 5 to $10 \%$ of the Dutch gillnet fleet, using the recommendations from EU Regulation 812/2004 as a guideline. We had a number of challenges which meant that not all days where REM systems were onboard of vessels could be analysed. This was due to three main reasons: 1 . the system not functioning, 2. the REM footage not being suitable for analyses (e.g. night-time fishing) and 3. limitation of resources allotted for the analyses. Even so, for both the combined gear types (11\%), as well as single-walled gillnets (10\%) and trammel nets (37\%) separately, we exceeded the coverage of fishery effort we had aimed for. The efficiency of obtaining REM footage that can be analysed could probably be increased in the future by solving some of the technical issues we encountered.

It is important to note that even though we reached the advised percentage of coverage, we only registered very few bycatches during our almost 4 years of data collection. With the knowledge we now have about this fleet and its bycatch rate, obtaining an appropriate sample size would be considered a higher priority than obtaining a 5 to $10 \%$ coverage of the fleet effort. Our results highlight that in areas of comparatively low fishing effort, to get sufficient bycatch events to allow a more in depth interpretation of patterns, one would either have to extend the sampling to a larger fleet (ideally covering $100 \%$ of effort), or would need to extend the sampling over a longer time period. However, in most cases restraints in funding, logistics as well as the availability of the fishing community will guide sampling design.

\subsubsection{Representative sample}

As described in the methods section, it is very difficult to obtain a random sampling of fishing effort for any fishing fleet (or section thereof). This is one of the challenges of most monitoring programs for bycatch of marine animals world-wide (e.g. Benoit and Allard, 2009), and this is a particular problem when dealing with a small fleet that has highly diverse vessels which are not consistent in their fishing operations over time. Theoretically one could also use randomly selected fishing days (or a similar measure reflecting fishing effort across a fleet), but in practice vessels, not fishing days, are sampled for practical reasons. Vessel selection in our project was already restricted by technical limitations (no frame for camera, no wheelhouse) as well as very low effort (very few fishing days per year) for a large proportion of the fleet. In addition, from our selected vessels several had been sold or had to be replaced. One possible solution to the sampling challenge would be to change the current technical set up of the REM system. A more flexible set up that could be switched between vessels in a random way could make it more efficient. It would also allow a higher coverage because the system could be switched to another vessel if it stops fishing or changes gear (Scheidat and Königson 2016). Such systems are currently under development but were not available during this study.

The selection process for the participating vessels was based on voluntary participation. It has been suggested that potentially those fishermen might have a way to reduce the probability of catching a harbour porpoise, e.g. by altering their fishing behaviour, and that this would bias the results. Based on the fishing statistics, (e.g. net use, seasonality, location) we could not find any indication that the non-selected parts of the fleet showed a different type of fishing behaviour than the participating vessels. But we can also not be certain if and to what degree fishermen can actively avoid bycatch.

One way to approach the potential bias inherent in voluntary participation is to build a good working relationship with the participating fishermen as well as invest in the developing of mutual trust. As 
described in this report, this is not always a smooth process. However, throughout the project, in particular after the challenges of the first two years were mastered, the crews of the vessels showed active participation and interest in the project. One example of how this was apparent was their willingness to make sure bycatches were not only registered timely, but also landed and available for pathological analyses whenever possible. This is not trivial as bycaught porpoises not only take considerable space on the small vessels, they also can cause a lot of (negative) attention if visible when coming into the harbour. We noticed that even when REM systems had been removed or were known to not be functioning fishermen would continue to report (and land) bycaught animals. Our experience indicates that, at least for the monitored section of the fleet we worked with, the bycatch events were shared willingly.

Keeping the above limitations and the potential bias they might cause in mind, a lot of effort was put in the selection process of the participating vessels to approximate a random selection as much as possible. A comparison of our actual sample with the actual effort during the study time indicates that the coverage of our sample fleet with regard to effort and net use is similar to the overall fleet (details can be found in Annex I and II). However, it is not guaranteed that the aspects of the sample we investigated (e.g. spatial coverage, temporal coverage, net type) where the only ones relevant.

Based on the existing information there is no indication that there is a difference in bycatch rate between non-sampled parts of the fleet and the sampled part. However, a properly randomized sampling of fishing effort (e.g. through the use of different REM systems) would be ideal for future studies to avoid any bias of known or unknown sources.

\subsubsection{Extrapolation of effort data}

The bycatch rates of the sampled portion of the fleet will need to be extrapolated to the total fleet to produce the total estimate of bycatch. Ideally the extrapolation factor that one would apply should have a linear relation to bycatch, this means that if fishing effort increases, bycatch should increase by the same factor.

A number of different units of effort can be considered, such as the weight of the landed catch, the number of days at sea, the number of fishing days, the number of fishing operations (hauls) and a measure of fishing effort such as $\mathrm{km}$ of netting or netting $x$ soak time. One of the main challenges is that these units of effort need to be available for every fishing day conducted by the entire fleet.

Fishermen are required to note down a range of different information in their fishery logbooks. It is important to realize that the reason the data has to be registered in logbooks is to assess compliance, not to conduct research. When trying to use it for assessment of effort, the limitations become evident. While ideally the records that are kept by the fishing fleet should include a high level of detail - such as haul number, net length, net type and soak time - this is not always the case and leads to large gaps in data. For vessels of a length above $12 \mathrm{~m}$ Vessel Monitoring System (VMS) data can also be used to calculate some of the fishing activities and estimate effort. Herr et al. (2009) used VMS data for vessels more than $15 \mathrm{~m}$ to estimate their fishing effort as well as the overlap with porpoise distribution in German waters. As the majority of the Dutch gillnet fleet is below $12 \mathrm{~m}$ in length, the VMS data is not available for the larger part of this fishing sector.

Landed weight of fish (in kg or ton) is a comparatively easy information to obtain. Nevertheless, there are also some problems associated with this data. First, the declared landings need to be accurate, as under-reported landings will bias a bycatch estimate as much as they bias the catch estimate. Catches of less than $50 \mathrm{~kg}$ do not have to be reported (but can be). Secondly, one assumes that the number of cetaceans caught per ton fish landed remains constant over the sampling period. Fish catches per unit effort tend to vary in relation to fish stock size, but it cannot be assumed that the bycatch rate of a cetacean in relation to fish catch will remain constant over time.

Fishing days are used as a standard proxy of fishing activity. It has the advantage that it is less likely to be misreported than landings. However, a fishing day can represent a very different amount of 
fishing effort for vessels of different sizes using different gear length or numbers. If this measure is used, it is important that the observer scheme is appropriately stratified to ensure that fishing effort is approximately equal for vessels within each category or stratum before the total bycatch is extrapolated. This is what we attempted to do for the Dutch commercial gillnet fleet by stratifying by gear type - however the very low number of bycatch events makes this challenging and asks for caution when interpreting the results. In many studies fishing days are not used but instead "days at sea"; this can be a misleading value for the total effort as it is not the same as actual fishing days (Vinther and Larsen 2004).

A number of studies have tried to evaluate fish catches in gillnets in relation to effort expressed as net length and soak time. They have found that a number of factors such as gillnet saturation, fish behaviour, fish density and fish escapement play important roles, making a prediction of catch rate for fish difficult (e.g. Minns and Hurley 1988; Hansson and Rudstam 1995; Prchalová et al. 2011). For cetaceans it is also not clear if net length and soak time are a good predictor for bycatch, and unfortunately the measure of soak time is rarely if ever available in the official fleet records. Bycatch can also be expressed in terms of the number of hauls, unfortunately these are also not recorded systematically.

When analysing the availability of net length per vessel per fishing day from the logbooks it became evident that a large proportion of all fishing days that were recorded during the study period did not have reliable information on net length. The records which did have numbers were recorded in three different units, $\mathrm{m}$ length, $\mathrm{km}$ length and number of $50 \mathrm{~m}$ long nets, but did not list the units. In addition many records were nonsensical, e.g. including a value that would not be feasible in either of the three units. Most likely this indicated typing errors when the data was transcribed or an error when it was recorded. For this study a number of assumptions were made to fill in the net length per year and vessel, but ideally this value would be provided in the database with accuracy. More importantly when interpreting net length per day as a metric for fishing effort it is important to recognize that this does not take into account the number of nets set per day. This could be estimated by applying number of hauls per day, but as stated before, that data is not available in the required quality.

Of the three different effort types that were used, fishing days consistently resulted in the lowest estimates of bycatch rate. This can best explained by the fact that the fleet is very diverse, and that the actual fishing effort based on days fishing will be grossly overestimated for some sections and underestimated for others. For example, a small coastal fishing vessel of $2.50 \mathrm{~m}$ length would land much less fish and use much shorter nets per fishing day, than a $15 \mathrm{~m}$ vessel that might operate $25 \mathrm{~km}$ of net length during one haul. So while the effort expressed as fishing day would be the same for these two vessels, the difference in the length of net deployed, and thus also the amount of fish caught, can be very large. If all other conditions are the same, one can assume that the length of the net is related to the probability of porpoise chance for bycatch. For this study we decided that the metric net length, even though it has some caveats, is the most reliable to use. This is because it does reflect actual effort better than fish days, and at the same time has a lower C.V. than the effort of ton fish landed. As different studies use different efforts, we provide all information here to allow a comparison of the results with other studies.

For the future it would be highly recommendable to have a more streamlined approach to estimating bycatch rates using the same effort value(s) for all gillnet fleets. That way the comparison of bycatch rates obtained by different countries or for different fleets or sections of fleets would be simplified.

\subsection{Harbour porpoise bycatch}

\subsubsection{Bycatch in relation to fishing effort and net type}

Gillnet fishery is not easy to define, as the exact type of fishing activity can vary on a multitude of factors, including the mesh width of nets, the height of nets, presence/absence of a drift line and the use of mono- or multi-filaments. In the last years it has been assumed that almost all bycatch of 
harbour porpoise in the North Sea occurs in nets aimed for cod, turbot and flat fish using large mesh sizes (Couperus et al. 2009). This assumption was based on a number of studies investigating the Danish fishery (Vinther 1999, Vinther \& Larsen 2004). In their research they found no bycatch in the small-meshed nets with a low net height, which is the fishery aimed at catching sole. In principle the expectation was that the same should hold true for the Dutch sole fishery. However, there had been some indications that the Danish situation might differ from the Dutch one. In 2003 Flores (2003) reported 7 bycaught porpoises during 6 trips with gillnet fishermen in the southern North Sea, mainly in Dutch waters. One porpoise was caught in one of two trips (duration 3-4 days) by a (German) fishing vessel using low set single-walled gillnets aimed at sole. Flores further reported 6 bycaught porpoises during one trip (5 days), 4 of which were caught in the Norwegian EEZ (targeting cod with cod nets, not at wrecks). During three more trips (3-6 days) targeting cod with cod nets at wrecks no bycatches were observed.

During the present study there were no bycatches registered in the single-walled gillnets that were aimed at cod or sea bass, however outside the scope of the project, a bycatch was reported by one of the participating fishermen using a single-walled gillnet targeting for seabass ('zeebaarsnet'). The chance of a bycatch was 2 to 10 fold higher for the trammel nets than for the single-walled gillnets. However, because the effort of the Dutch commercial fishery in the single-walled gillnets (which are primarily sole nets) is currently about 10x higher than for trammel nets, the estimated annual number of bycatches for that section of the fishery is higher.

It has been hypothesized that there might be a particular bycatch problem with wreck fisheries in the North Sea. In these fisheries short net lengths (less than 400m) are deployed over wrecks and rough ground. The nets are single-walled gillnets and the target species are larger cod that are thought to aggregate in these areas. While in 2008 the cod catches by Dutch gillnetters were still good (Couperus et al. 2009), they decreased dramatically during the last 10 years. The low cod catches off the Dutch coast, as well as a reduction in fishing quota in the last years (ICES, 2018), has impacted the fishing practice of Dutch fishermen also. During the selection process of the vessels for this study, the information if fishermen had been conducting wreck fishery in the past was considered as an important ranking value. However, during the study period none of the participating fishermen actually conducted wreck fishery. While currently the cod stock in the southern North Sea is on a low level, this may change after a few years of high recruitment (ICES, 2018) and the wreck fishery might increase again.

\subsubsection{Animals missed}

Our study confirmed earlier findings that it is not uncommon for bycaught harbour porpoises to fall out of the nets when these are hauled in. A Danish REM study found that 7 of the 14 porpoises observed on the videos but not recorded in the skippers' logbooks dropped out of the nets before being seen by the fishermen on board (Kindt-Larsen et al. 2012b). The authors believe that the increased weight of the porpoises when they brake the surface leads to them to dropping out. At this point fishermen as well as on-board observers are often busy handling the catch and therefore miss the porpoise (KindtLarsen et al. 2012b). In our study the two animals that had fallen out of the net during the haul had not been noticed by the skipper. This also underlines the importance of having cameras installed that will show not only the net hauler, but also the water surface where the net comes up and the area around. In addition, the possibility to rewind, stop and zoom the video is an advantage to check if an animal fell out of the net.

It is not known if bycaught animals drop out while still under water; most likely most of those would float to the surface. A number of studies used dedicated observers to investigate the drop out events in more detail by watching the area of the net in the water (Bravington \& Bisack 1996, Tregenza et al. 1997), and their results indicate that up to $58 \%$ of animals will not reach the deck.

An additional source of missed animals comes from animals not recorded by either the fishermen and/or during the REM analyses. We re-analysed about $10 \%$ of our dataset to assess if our REM team missed any animals, but found no new bycatches. However, this does not mean that no bycatches are missed. We know that an additional animal (fallen out of the net) was seen during the review of the 
known bycatch events on REM footage. For our study we considered a number of different approaches, but finally concluded that it was not possible to assess a reliable correction factor. To quantify observer bias, as well as the rate of animals that fall out of nets, one would need to analyse a dataset with a higher number of bycatches.

\subsection{Management and conservation context}

\subsubsection{Acceptable bycatch numbers}

ASCOBANS recommends that that "total anthropogenic removal is reduced by the Parties to below the threshold of 'unacceptable interactions' with the precautionary objective to reduce bycatch to less than $1 \%$ of the best available abundance estimate and the general aim to minimise bycatch (i.e. to ultimately reduce to zero)" (ASCOBANS 2006, 2016). The interim aim is a reduction of the "total anthropogenic removal' to $1.7 \%$. This latter value includes any human activity that causes porpoises to die, such as for example noise, pollution or ship strike. Bycatch has been identified as the major conservation threat for small cetacean worldwide (e.g. Read et al. 2006, Reeves et al. 2013).

Ideally all human-caused mortality would be assessed on the level of the relevant population. This could be the North Sea population, which has an estimated size of 345,373 animals (95\% C.I. 246526 - 495752) for the ICES assessment unit North Sea (Hammond et al. 2017), or a management unit of the southern North Sea. However, this would mean that information on mortality - or in our case bycatch - has to be available from all countries operating in the area where the population occurs. Unfortunately, even with the EU regulation in place, the compliance of EU countries to provide reliable bycatch numbers is low. ICES (International Council for the Exploration of the Sea) has made estimates of bycatch mortality for their North Sea assessment (ICES, 2016) unit. They had to make a number of assumptions to address data gaps, e.g. for fishing gear type, vessel size and distribution of fishing activity over space and time. The results are based on an actual observer coverage of the monitored fleet (category net level 4 metiers: trammel nets, set nets and driftnets) of only $0.28 \%$. They collated observer data over the years 2006 to 2013 to obtain bycatch rates per observer days (aka fishing days). The resulting bycatch rate ranged from 0.028 to 0.045 porpoises per fishing day. This rate was then applied to the fishing effort for 2013, resulting in an estimate of annual bycatch ranging from 1235 to 1990 porpoises for the North Sea assessment unit. The best available abundance estimate for harbour porpoise in the North Sea (345400 animals in 2015, SCANSII) was then applied to estimate the annual bycatch percentage of 0.36 to $0.58 \%$.

When comparing the North Sea estimates with the Dutch bycatch estimates it is advisable to use caution. Not only are there a lot of underlying assumptions that make the ICES values less reliable, in addition the time area that is covered by the ICES analysis and the Dutch project differs substantially. Fishing changed in the last ten years, both in terms of effort and gear used, so applying an average value for such a time period from 2006 to 2013 is problematic. What the calculations by ICES highlight is that the data gaps are considerable.

Interpreting if a bycatch number is "acceptable" or not can only be done if one has some kind of conservation objectives as a framework. Scheidat et al. (2013) calculated the "acceptable" number of deaths for Dutch waters under the ASCOBANS conservation aims. The resulting numbers are annual values of a maximum death of 802 animals ( $1.7 \%$ aim) and 472 animals ( $1 \%$ aim). Applying the Potential Biological Removal (PBR), which is used under the US Marine Mammal Protection Act, would result in 269 animals. And finally, applying the Catch Limit Algorithm (developed under the Revised Management Procedure of the International Whaling Commission; Punt and Donavan 2007), which has been calculated for the North Sea and was downscaled for Dutch waters, the resulting value is 183 porpoises that could be killed per year and still be within aims set by the conservation objective. There are indications that the simple $1 \%$ or $1.7 \%$ rule might lead to an overestimation of the number of animals that can be taken without endangering the population (Scheidat et al. 2013), and a number of new approaches are being currently developed. These would calculate an actual "allowable mortality" 
for each assessment unit separately (e.g. ASCOBANS 2015). Ultimately, what type of framework is used is a societal decision.

The results from this study show that the average annual bycatch percentage (0.05 to $0.07 \%$ ), as well as the "worst case value" $(0.30 \%)$, of the Dutch commercial gillnet fishery is well below the current conservation target of ASCOBANS of less than $1 \%$. This does not take into account that there are other causes of direct mortality for porpoises (e.g. other fishing fleets, underwater noise, ship strike, explosions) that will also contribute to the overall number of porpoises annually killed through human activities.

\subsubsection{Other sources of bycatch in Dutch waters}

The aim of this study was to quantify bycatch of harbour porpoise in the Dutch commercial bottom set gillnet fleet. However, we are aware that this is not the only fishing operations in Dutch North Sea waters that can cause bycatch.

\subsubsection{Recreational bottom-set gillnet fishery}

The local municipalities of Schiermonnikoog, Ameland, Terschelling, Vlieland, Texel, Zijpe, Zandvoort, Katwijk and Westland can provide permits for recreational gillnet fishery in their respective fishery zones (Staatscourant 2012). To obtain a permit for the recreational gillnet fishery a number of criteria need to be fulfilled by the applicant: a maximum total net length of $50 \mathrm{~m}$, a maximum net height of $65 \mathrm{~cm}$, a simple (single-walled) net type ('botwant'), placement between the high water and low water line and a maximum soak time of 24 hours and only one net per person.

Knowledge on the scale of this fishery is scarce and patchy (Ministerie van EZ, 2013). Catches in the recreational fishery don't have to be registered and logbooks are not filled in. Jongbloed et al. (2013) used the available information to estimate that the total effort could lie between 100 and 16400 fishing days per year. A recent study (van den Hammen \& de Graaf 2017) analysed the activities of recreational fisheries in more detail and found that 713 gillnet fishers were given a permit to fish with gillnets in 2013. The survey results indicated that 39\% of these fished 1-5 times per year and $6 \%$ indicated that they fished more than 50 times.

To our knowledge bycatches of dead porpoises have not been registered in this fishery, but there is a record of a live catch on 23 February 2011 close to Katwijk (Jongbloed et a. 2013) and a second one on 5th April 2014 close to Noordwijk (Scheidat et al. 2016). Even though these nets are bottom-set, because of the shallow coastal waters, the porpoises were able to reach the surface to breathe.

Recreational gillnet fishery in Belgium (Haelters \& Kerckhof 2004, Haelters et al 2004) have found regular bycatches of harbour porpoise. As a result since March 2015 the use of gill - and trammel nets is prohibited. However, the situation at the Belgium coast with large low and high tide, deeper water and strong currents cannot directly be compared with the Dutch recreational gillnet fishery (Jongbloed, 2013).

As this study as well as other research world-wide shows, we can be certain that where there is an overlap of porpoise occurrence and gillnets, there is a probability of bycatch. However, for the recreational fishery we are lacking reliable data on the fishing effort and the number of bycatches (dead or alive) occurring. The Dutch recreational fishery is a hitherto unquantified source of potential bycatch.

\subsubsection{Dutch weir fishery}

For completeness we would like to mention another account of a live bycatch of a porpoise. There is a very small-scale traditional "weervisserij" (weir fishery) in the estuary of the Oosterschelde that targets anchovy. In June 2013, a harbour porpoise swam into a weir and was released alive (cited in Scheidat et al. 2016). Live catches of porpoise in such type of fishery are common in the Danish pound net fishery and the Canadian weir fishery (Scheidat et al. 2016). The animals are not entangled in the nets and can swim in the weir and thus are released alive. These type of events are extremely rare in Dutch waters. 


\subsubsection{Non-Dutch bottom-set gillnets}

Other countries also fish in Dutch waters and those activities are likely to contribute to the bycatch of porpoise in Dutch waters. While not within the objectives of this study, we did explore the data available through the Joint Research Centre database (stecf.jrc.ec.europa.eu) to get an indication of the scale of the non-Dutch fishing effort in the study area. This data is available per ICES rectangle. Using all those ICES rectangles completely covering Dutch waters (37F3, 36F3, 32F3, 31F3, 38F4, $37 F 4,36 F 4,35 F 4,34 F 4,33 F 4,32 F 4,36 F 5,35 F 5)$, a general idea can be obtained on how much of the gillnet fishing effort is conducted by fishermen under a Dutch flag, and how much by other countries. Table 11 provides an overview of this data.

Table 11: \% fishing effort as landed fish (tons) for the sum of those ICES squares (37F3, 36F3, 32F3, 31F3, 38F4, 37F4, 36F4, 35F4, 34F4, 33F4, 32F4, 36F5, 35F5) completely in NL waters. Shaded cells show actual fishing effort. Data adapted from stecf.jrc.ec.europa.eu (GNS = single-net gillnets; GTR = trammel nets).

\begin{tabular}{ccccccc}
\hline & \multicolumn{2}{c}{$\mathbf{2 0 1 4}$} & \multicolumn{2}{c}{$\mathbf{2 0 1 5}$} & \multicolumn{2}{c}{$\mathbf{2 0 1 6}$} \\
\hline country registry & GNS & GTR & GNS & GTR & GNS & GTR \\
\hline Belgium & 0.2 & 0 & 0 & 0 & 0 & 0 \\
Germany & 7 & 0 & 11 & 0 & 13 & 0 \\
Denmark & 31 & 0 & 28 & 0 & 18 & 0 \\
England & 6 & 0 & 1 & 0 & 4 & 0 \\
France & 0 & 0 & 0 & 0 & 0 & 1 \\
non-NL vessels & 44 & 0 & 41 & 0 & 35 & 1 \\
The Netherlands & 56 & 100 & 59 & 100 & 65 & 99 \\
\hline
\end{tabular}

Trammel nets (GTR) are used in Dutch waters pretty much exclusively by vessels operating under the Dutch flag, and all effort of these is in the coastal areas.

For single-net gillnets (GNS) the Dutch fleet lands about $60 \%$ of all fish, the rest is primarily landed by vessels that are operating under Danish and German flags. It should be noted that the flag of a vessel does not necessarily correspond to the nationality of the crew. More information on how the spatial distribution of effort differs between Dutch and non-Dutch operating vessels can be found Annex VI.

Interpretation of this data in terms of overall bycatch estimates for the Dutch waters combining all vessels is difficult as it is not known if the estimated bycatch rates for this project could be extrapolated to vessels from other countries. Also, the fishing effort information provided is not entered consistently between countries and does not have a spatial resolution that would allow calculation of effort for Dutch waters only. One conclusion we can make is that any additional bycatch from non-Dutch vessels would primarily come from single-net gillnets, as less than $1 \%$ of non-Dutch vessels use trammel nets in Dutch waters.

\subsubsection{Ghost nets}

Ghost fishing is defined as fishing by (passive) fishing gear that has been lost or abandoned. Generally this type of gear has a reduced ability to catch animals over time as nets tend to entangle or roll up. In addition nets are colonised by marine organisms which also reduces their catch ability (Revill and Dunlin, 2003; Brown et al. 2005).

Wrecks are attractive for fishing, and due to the structures net losses are more likely to occur here. From 2011 to 2013 the "Stichting Duik de Noordzee schoon" (Foundation Dive for a clean North Sea) has conducted 168 dives with volunteers to clean 100 wrecks in the North Sea from nets (Last, v. d. 2011). Up to this point porpoises have not been seen in nets, but seal bycatch has been noted (Oscar Bos, pers. comment). 
The extent of ghost gear existing in the Dutch North Sea is not known, and it is not clear if any porpoise bycatches occur. Most current research indicates that likely ghost nets around wrecks are not of significant concern for continuing catches (Macfadyen et al. 2009) and there are no mentions of porpoise catches in ghost nets.

\subsection{Bycatch information gained from necropsies}

The Netherlands has a long-established stranding network covering most of its coastline which is run mainly by volunteers. When a dead porpoise is found, members of the network recover the carcass and if it is relatively fresh they contact researchers of the Department of Pathology of the Faculty of Veterinary Medicine, Utrecht University, who determine whether an animal is suitable for necropsy. This research aims to determine the cause of death of the investigated cases. Harbour porpoises for which bycatch is suspected are subdivided in categories based on the certainty of this diagnoses, which includes the categorization into certain, highly probable, probable and possible bycatch. The category "certain" is not given to stranded animals, but only to those found in nets or brought ashore by fishermen and for which no other cause of death is established during necropsy (more details on the necropsy protocol and the results from this study is provided in Annex IV). All strandings are entered into a database at the National Museum of Natural History Naturalis in Leiden (www.walvistrandingen.nl).

Stranding networks in combination with necropsies can provide important data on bycatch occurrence, and are the only source of information in cases where dedicated programs to monitor bycatch are lacking (ICES 2017a,b). However, when interpreting stranding and necropsy data to obtain bycatch rates some important limitations need to be considered.

When porpoises die at sea, independent if the cause of death is natural or anthropogenic, their "behaviour" at sea and consequently their chances of stranding on a beach is influenced by drift processes (wind and tide) as well as carcass buoyancy (size, weight and state of decomposition) (Peltier et al. 2013). A drift model by Peltier et al. 2013 shows that the probability of a porpoise stranding varies throughout the year due to the strong differences observed in drift conditions between winter and summer (due to the seasonal differences in wind conditions). Peltier also concludes that porpoises that originate further offshore could seasonally be too far away to reach a coast within 30 days and that the probability that cetaceans originating from coastal areas get stranded is always higher. In the model, Peltier et al. did not consider the impact of temperature on the buoyancy of a carcass. Moreno et al. (1993) conducted a small-scale experiment with porpoise carcasses. Even though the results are based on only two animals, there was a distinct difference in "behaviour" of the two carcasses between seasons. In winter months with cold water temperature the carcass stayed submerged for weeks. During this time it was subject to intense scavenging pressure, which increased the probability of it staying submerged because of puncture holes preventing gas to build up in the body cavities. In contrast, in summer the carcass floated to the surface within days, and even though general decomposition is faster in warm water, scavengers (which were primarily benthic) had less opportunity to feed on the carcass. Moreno et al. postulates that animals dying in summer would most likely have a higher chance of stranding.

Stranded porpoises are a subsample of all porpoises that die within the population and the necropsied harbour porpoises are a subsample of all those stranded. Although it is encouraging that necropsies are taking place, funding for necropsies has been limited in previous years (2014 and 2015) and since 2016 , only about $10 \%$ of all stranded porpoises are subject to post-mortem investigations. When the porpoises are found they are categorized in so called Decomposition Condition Codes (DCC), with 1 being a very fresh animal and 5 being remains of an animal. Animals with a code of 1 or 2 are the preferred sample for pathological exams as it is possible to gain lots of information from these cases. Although less frequent, animals in code 3 are also examined, but carcasses in codes 4 and 5 immediately go to destruction without any further examination.

The decomposition state of a stranded animal is linked to its location when it died and it is likely that fresh carcasses represent animals that have died close to the shore. Thus the distribution of causes of 
death found in the sample most likely is not representative for all porpoises in Dutch (or adjacent) waters, but primarily reflects the status of porpoises occurring in the coastal region.

When choosing which animals are brought in for pathological exam, logistical constraints mean that more animals are proportionally necropsied from areas that are easier accessible and where transport of the animal is feasible (Bijsterbosch \& Hermus, 2014). For similar reasons, although the stranding network covers all of the Dutch coastline, there are indications that some areas are underreported (Bijsterbosch \& Hermus, 2014) and that there is a substantial difference between reported and expected strandings for the Wadden Sea (Camphuysen et al. 2008). And finally, the freezing (and subsequent thawing) of animals can cause artefacts that make an accurate diagnosis of cause of death more difficult (Roe et al. 2012), which is why since 2014 all attempts are made to necropsy very fresh animals without freezing them prior to the examination.

In table 12 we provide an overview of the number of necropsies conducted for the years 2013, 2014, 2015 and 2016, as well the number of animals where cause of death was bycatch (categories certain, highly probable, probable and possible).

The bycatch category "certain" is only given to those specimens provided by the fishermen that were part of the REM project. When considering the sum of all other bycatch categories (including possible, which is generally excluded due to the uncertainty) the \% of stranded and necropsied porpoises that were considered bycatch varied between $5.3 \%$ and $9.1 \%$ per year. Using only the \% of bycatch for those animals that had a known cause of death these values range from 7.1 to $11.1 \%$.

Table 12. Overview of strandings numbers and necropsy results for porpoises for the years 2014, 2015 and 2016 (source: University of Utrecht).

\begin{tabular}{|c|c|c|c|c|c|c|c|c|c|c|}
\hline $\begin{array}{l}\frac{1}{\mathbb{N}} \\
\stackrel{\nearrow}{\nearrow}\end{array}$ & 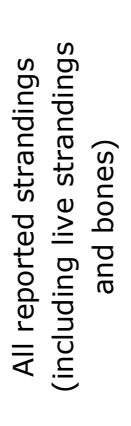 & 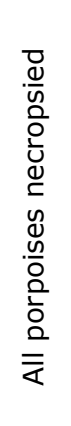 & 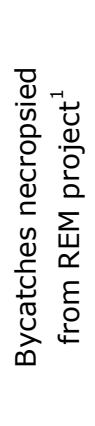 & 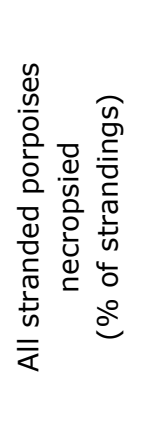 & 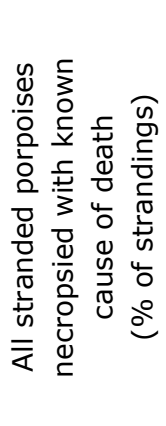 & $\begin{array}{l}( \\
\frac{0}{0} \\
\frac{0}{0} \\
00 \\
0 \\
0 \\
\frac{1}{2} \\
\frac{2}{5} \\
\frac{0}{1}\end{array}$ & $\begin{array}{l}\text { use } \\
\text { eat } \\
\text { cat } \\
\text { and }\end{array}$ & $\begin{array}{l}\frac{0}{0} \\
\frac{0}{\tilde{n}} \\
\stackrel{0}{0}\end{array}$ & 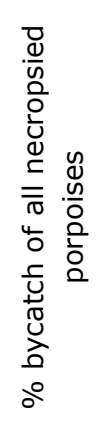 & 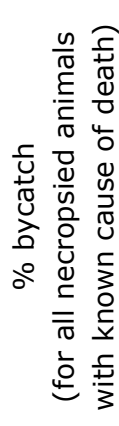 \\
\hline$\stackrel{m}{\stackrel{m}{0}}$ & 880 & 247 & 2 & $\begin{array}{c}245 \\
(27.8 \%)\end{array}$ & $\begin{array}{c}105 \\
(11.9 \%)\end{array}$ & 0 & 5 & 17 & $9 \%$ & $21 \%$ \\
\hline 龒 & 582 & 59 & 2 & $\begin{array}{c}57 \\
(9.8 \%)\end{array}$ & $\begin{array}{c}24 \\
(4.1 \%)\end{array}$ & 1 & 0 & 2 & $5.3 \%$ & $12.5 \%$ \\
\hline in & 309 & 34 & 2 & $\begin{array}{c}32 \\
(10.4 \%)\end{array}$ & $\begin{array}{c}28 \\
(9.1 \%)\end{array}$ & 1 & 0 & 1 & $6.3 \%$ & $7.1 \%$ \\
\hline $\begin{array}{l}0 \\
-1 \\
0\end{array}$ & 661 & 67 & 1 & $\begin{array}{c}67 \\
(10.1 \%)\end{array}$ & $\begin{array}{c}54 \\
(8.2 \%)\end{array}$ & 2 & 2 & 2 & $9.1 \%$ & $11.1 \%$ \\
\hline
\end{tabular}

If one was to apply the percentage of bycatches found for all necropsied animals to the number of overall strandings (table 12), the resulting bycatch numbers per year would be between 19 and 79. If one applies the percentage derived from only those animals that had a known cause of death, the extrapolated annual bycatch would be between 22 and 183 .

\footnotetext{
${ }^{1}$ These animals have been landed by the participating fishermen from the project 'Onbedoelde bijvangst in beeld'. They are considered "certain" in the database. An additional two animals were necropsied in 2013, one more in 2017. One of these had been caught post-mortem.
} 
Using the ratio of bycaught animals to extrapolate a bycatch rate has been discouraged by a number of experts as an unreliable source of bycatch numbers, mainly because the determination of cetacean cause of death is highly related to the decomposition status of stranded carcasses (WGBYC, 2007). However, more recently Peltier et al. (2016) used strandings data on common dolphins in combination with species-specific drift and buoyancy models. This new approach addresses some of the caveats mentioned above and it could also be a promising future approach to use strandings data to obtain reliable information on bycatch occurrence.

In the Dutch situation, there is an example that a drift model seemed to have successfully predicted the location and time of a stranding. Van Helmond and Couperus (2012) mention a porpoise, bycaught in a set gillnet $1 \mathrm{~km}$ off the coast of Rotterdam on 16 February 2011. The drift model used by the local marine police predicted that it would strand after 5 days near Scheveningen. Indeed, on 21 February a fresh carcass of the approximate estimated length and with clear imprints of netting stranded within the predicted area, although there was no hard evidence that it was the same specimen. During our project four bycaught porpoises were not brought ashore. Plastic labels to be used on carcasses that would be released had been provided to the fishermen, but unfortunately none of these animals were labelled. Collection of this type of data would be very valuable to improving our understanding of the drifting behaviour of porpoise carcasses.

Currently any bycatch information derived from necropsied stranded porpoises need to be considered with caution as they are based on a biased sample. Nevertheless, the fact that the results from the REM study are in the same range does not point to any obvious incongruities between the two data sources. It is also interesting to point out that the \% of animals that had bycatch as a cause of death (of all with a determined cause of death) was more than in 2013 than in 2015 . The reasons for this variability are unclear, it could be caused by differences in sampling (e.g. sample size, locations) or in a change in mortality (e.g. change in fishing effort) or a shift in distribution of porpoises. One could hypothesize that the possible shift in the distribution of porpoises observed early 2015 to offshore waters (see 4.6) could have contributed to the lower stranding numbers as the probability of a carcass stranding declines with distance to shore.

\subsection{Mitigation of bycatch}

One of our aims was to assess what type of mitigation method should be applied if the results indicate that mitigation of bycatch is needed to obtain the "favourable conservation status" for harbour porpoises. Mitigation of bycatch can be done through two basic approaches - either a modification of the fishing gear or a change in fishery management. If mitigation is needed is a question that depends on the conservation aims and the policy decision.

One of the methods to reduce porpoise bycatch is to implement the use of pingers. These are acoustic deterrents that have been shown in trials to reduce bycatch of porpoises without reducing catches of target species (e.g. Kraus et al. 1997, Larsen et al. 2002; Larsen and Eigaard 2014). While EU Regulation 812 obliges vessels to use pingers on vessels of $12 \mathrm{~m}$ and more, there are some concerns about their use. There are studies indicating that if some pingers that are placed on the nets do not work, the gaps between functional pingers can lead to higher bycatches (e.g. Palka 2008). In addition both habituation (Cox et al. 2001) and habitat exclusion (Culik et al. 2016) are problematic. The negative impact of the noise that is introduced to the marine habitat by using pingers needs to be weighed carefully against any potential reduction in bycatch when considering their use. Early on in our study one vessel still had banana pingers deployed, however their use was stopped later. Due to the low number of bycatches it was not feasible to investigate the effectiveness of these devices. While they have been successful in some fisheries, the criticism remains that porpoises might get accustomed to them and also that they will be moving away from important feeding sites. This could have a high negative impact on the population, potentially exceeding the impact through fishery mortality. In the past the use of pingers has been investigated in Dutch waters (Siemensma 2014), but because of the low rate of bycatch it has not been possible to determine if they have been effective. Based on the current situation in terms of fishery effort and bycatch rates we propose that pingers are not made an obligatory mitigation method for the Dutch commercial gillnet fishery. 
Another option to reduce bycatch is to investigate a change of the design of the fishing gear. For porpoises experiments on changing the materials of the net have been tried out, but the results did not provide wide ranging success (e.g. Koschinski et al. 2006, Trippel et al. 2003).

If one has sufficient knowledge of both the fishing effort and the distribution of porpoises, time-area closures of fisheries might be an option for mitigation of bycatch. The effectiveness of time-area closures depends on a large number of parameters, and sometimes such mitigation action can have unintended impacts (O'Keefe et al. 2013). For example, a displacement of fishery and/or a change in effort and fishing methods, might lead to new conflicts in other areas. Read (2000) stated that time/area restrictions are unlikely to be effective in situations where there is little significant spatial or temporal variation in the bycatch rate, or in which there is considerable inter-annual variation in any spatial patterns.

In Dutch waters most fishing effort - and also most bycatches - occurred in a very coastal region. However, considering the current scale of bycatch in Dutch waters it is not likely areas of potential overlap can be identified. Maybe when more is known on porpoise individual behaviour "hot spots" and thus potential areas of overlap, also during specific times, can be identified. Based on this study there are too little bycatch events to determine different bycatch rates per areas or season.

\subsection{Porpoise distribution}

We already mentioned a notable change in harbour porpoise distribution over the last decades, the "return of the harbour porpoise" into Dutch waters (Camphuysen 2004, 2011). When the porpoise first made its comeback it was primarily seen in the late autumn to early spring. This seasonal pattern in occurrence was confirmed by land-based observations as well as aerial surveys conducted at different times in the year (www.trektellen.nl). However, in the last years the occurrence in the summer months has increased. Also porpoises in the last year have moved more into rivers, such as the Elbe, Weser and Eems, probably following migratory fish (Weel 2016; Weel et al. 2018).

In 2015 a distinct change in the occurrence of porpoise along the Dutch coastal area was noted. The land-based counts, which are aimed at seabirds but also record all marine mammal sightings, had a substantial drop in porpoise sightings (www.trektellen.nl). In February 2013 the sighting rate of porpoises per hour was 0.55, in February 2014 it was 0.40 , and in February 2015 it dropped to only 0.03 porpoises per hour. This pattern was also reflected in the strandings data where the values of all porpoises found in 2013 was 880, in 2014 this was 582 and in 2015 it was only 309 (Guido Keijl pers. communication). There were concerns that maybe porpoises had left Dutch waters, however, aerial surveys showed that the overall density had stayed the same (Geelhoed et al. 2015). In 2016 numbers returned to what had been seen in previous years with 661 strandings noted and this trend continues for 2017 with 683 porpoise strandings.

The most likely explanation for the (temporary) observed change in porpoise occurrence is that the animals moved further offshore. Obviously even such small movements of large sections of the Dutch population can have large impacts on the bycatch probability. Most of the fishing effort of the Dutch commercial gillnet fishery is very coastal. This means that if porpoises move out of the coastal area the bycatch events (by the Dutch fleet) would be expected to go down.

We are still a long way from understanding what drives these changes in porpoise distribution. But it is likely that with an always changing marine ecosystem - in particular considering the potential largescale impact of climate change on the North Sea system - they will continue to occur, making it more difficult to predict bycatch probabilities. This variability from year to year underlines the importance of conducting long-term monitoring studies for bycatch rates. 


\section{$5 \quad$ Conclusions and recommendations}

\section{The main conclusions of this project are:}

I. Harbour porpoises are bycaught in both single-walled gillnets and trammel nets.

Prior to this work it was assumed that the large majority, if not all, bycatch would occur in trammel nets. In particular single-walled gillnets aimed at sole were not thought to be a high risk for porpoises due to the comparatively low net height. This study showed this not to be true and highlights the importance of monitoring all types of gillnets during any study investigating cetacean bycatch.

II. The average annual bycatch of harbour porpoise in the Dutch commercial gillnet fishery for the study period (1 June 2013 to 31 March 2017) was 23 animals (95\% C.I. 2 - 44). The bycatch occurring in this fishery constituted between 0.05 and $0.07 \%$ of the Dutch porpoise population.

This study indicates that the annual bycatch mortality for the Dutch porpoise population is considerably below the (currently) advised threshold by ASCOBANS of no more than $1 \%$. The bycatch estimates did not include other gillnet bycatch. What type of threshold is considered an acceptable human-caused mortality for harbour porpoise ultimately needs to be a societal decision.

III. The low number of bycatch occurrences makes it impossible to identify any patterns of bycatch probability.

To effectively monitor a fleet having very rare bycatch events the sampling level needs to be adapted, for example by having a continuous sampling, ideally of the complete fleet. This allows an investigation of changes in bycatch rates over time and an increase in number of bycatch events would also allow a better interpretation of where bycatches occur and if there are links to the animals (e.g. sex, age). This could help to develop and implement efficient mitigation methods.

\section{Our recommendations for future actions are:}

I. Improve data collected on a national and international level in the electronic logbooks, aiming for consistency and completeness.

The application of bycatch rates to a fleet to obtain bycatch numbers is only as good as the underlying data of the fishing activities of that fleet. A lack of specific, accessible and reliable direct data from fisheries is a common challenge among all fishery types and for any type of monitoring project. Resources need to be directed to obtaining data that includes details on gear, time spent fishing and searching, catch rates and fine spatial and temporal information across the entire fishery. ICES as well as ASCOBANS have made recommendations in this regard and their efforts should be supported.

II. Measurement of fishery effort and estimation of bycatch rates in the Dutch recreational gillnet fishery and assessment of the bycatch rates by non-Dutch vessels operating in Dutch waters In this study we calculated the bycatch rates for the Dutch commercial gillnet fishery only. For a complete overview of overall mortality of porpoises in Dutch waters all gillnet fishery activities need to be considered. This includes the recreational fishery and any non-Dutch vessels operating in Dutch North Sea waters. International efforts should be focussed on harmonising data collection.

III. Invest in the development and application of a mobile REM system that can be rotated easily between vessels and that would address some of the technical challenges we encountered Random sampling of fleets remains a challenge. Ideally, monitoring of bycatch should either be done for the complete fleet, or fishing days should be monitored randomly across the entire target fleet (Northridge \& Fortuna 2008, Northridge 1996), or within each stratum of a fleet. However, practical and pragmatic constraints often limit the sampling pool. We recommend the development of a mobile REM system that could be installed in an easy way and rotated over the fleet. Currently a system called "CatchCam" is being developed and tested (pers. comm. v. Helmond) for catch monitoring. These devices are only a fraction of the cost from the current systems and are a promising way forward to allow randomization of the sample and to significantly increase the sampling size. 
IV. Continuation of the REM work in close cooperation with the gillnet fishing fleet, including other protected species in the monitoring (conforming with the new Data Collection Framework)

Within our study period we see that both porpoise distribution and fishing activity are very variable. Some of the factors impacting fishing activities can be identified, such as changes in target fish stocks, fisheries and marine protected areas management and economic factors (e.g. fuel prices). Understanding is lacking on how porpoise behaviour factors into this equation. As bycatch rates and bycatch estimates will not be constant over time we recommend that monitoring efforts continue.

This project had a difficult beginning and it took time for the work atmosphere between project partners and participating fishermen to move from uncertainty and distrust to effective collaboration. One example of positive change was the registration and landing of bycaught animals, even when REM systems were not active. For any project of this type to be successful, the fishing industry needs to be a respected partner that is involved in an early stage in the research design, who understands the aims of the programme, and can provide input to solve technical challenges. A future sustainable fishery that has minimum impact on the ecological health of the North Sea system is of interest to all stakeholders. Komoroske and Lewison (2015) highlight that to effectively address the new challenges in a changing world on ecological, social, cultural and economic levels, it is imperative to have the stakeholder engagement so creative solutions can be found without threatening fishers' livelihoods. This is certainly also true for the Dutch situation and we hope that in the future this cooperation between research and fishing community can be continued and strengthened.

V. Facilitate legal permission for the entire Dutch (commercial gill net) fisheries fleet to land bycaught porpoises for both monitoring and pathological investigation.

The necropsies of the bycaught porpoises lead to highly relevant results that can help draw conclusions on the health status of animals bycaught as well as what type of animals are caught. It also provides reference data vital to identifying bycaught animals that are found stranded. The landing of porpoises should be facilitated and legally permitted so that fishermen can work together with the Faculty of Veterinary Medicine (University of Utrecht, Department of Pathobiology) to provide animals. Currently landing is not permitted and hence illegal, and in theory fishermen could be prosecuted.

VI. Based on the current fishing effort and net types used we do not recommend the obligatory use of pingers as a mitigation measure.

Considering the low number of bycatch events during the study period, and the potential of the sounds emitted by pingers leading to habitat degradation, it does not seem to be an effective measure to implement the wide use of pingers for the Dutch gillnet fleet. A voluntary use of pingers should be facilitated.

As a final point, the current observer programmes are designed to obtain bycatch rates for a specific fishing fleet per country. The ultimate aim is that total fishing effort and total bycatch numbers will be known for all fleets operating in the North Sea and that these values can then be used to estimate the impact on the North Sea population of harbour porpoise. This approach only works if all countries provide reliable information with a similar (high) quality standard. Bycatch issues cannot be addressed on a national level alone. In this light the implementation - from January 2017 onwards - of monitoring of protected species (including sea mammals, birds, turtles and fish species) in the Data Collection Framework of the Common Fisheries Policy (CFP) is an important step. It will broaden the obligations of the member states. However, this development in itself provides a challenge for the Member States of the European Union, because it is extremely challenging to design observer programmes which target all species protected under European Union legislation and international agreements (more than 200) which may be bycaught incidentally. For this reason the design and coverage of the fleets is initially based on the requirement for the assessment of commercial fish species and not on known bycatch issues. The new Framework is a chance to provide an ecosystembased approach allowing the problem to be identified on an international level, but it will need considerable effort of all parties involved. 


\section{Acknowledgments}

Without the cooperation of the participating fishermen, this study would not have been possible. We would like to thank all fishermen who took part in the project over the years. We'd like to thank Rems Cramer in particular, who was a participant, but also spokesman for the fishermen. We would like to thank the Dutch Fishermen's Association (Nederlandse Vissersbond), and in particular Derk Jan Berends, Durk van Tuinen and Egbert van der Tuin and the Fishermen's organisation VisNed, in particular Geert Meun and Wouter van Broekhoven for their fruitful cooperation and feedback during the project.

We would like to thank the company Piet Brouwer Electrotechnology that took care of the technical installations, in particular Gerrit Barends, Bram Brouwer, Jan Korf, Reinier Romkes, Flerik van Veen and Albert Jan de Vries.

We also acknowledge the work done by Faculty of Veterinary Medicine, University of Utrecht, Department of Pathobiology, who was responsible for the necropsy of the bycaught harbour porpoises, especially Lonneke IJsseldijk, as well as Andrea Gröne, Lineke Begeman and Liliane Solé.

We would like to thank Jaap van der Meer, NIOZ, for advice and external review in his capacity as chairman of the porpoise advisory committee (Bruinvis adviescommissie). We would like to thank our international colleagues Lotte Kindt Larsen for her pioneering work in Denmark with REM monitoring in this type of fisheries and for her advice and feedback since the start of our project and also Simon Northridge and Russell Leaper for providing advice. We would like to thank Guido Keijl for the strandings data from the database at the National Centre for Biodiversity Naturalis.

We would like to thank all colleagues and former colleagues of WMR that have contributed in some way to this project. In particular we would like to thank Anneke Rippen, Elisa Bravo Rebolledo, Narangerel Davaasuren and Daniel Benden for their help during this project with the data collection and analysis. We would like to thank Mardik Leopold for investigating the stomach contents of the landed porpoises and Hans Verdaat for his help. We thank Edwin van Helmond for the internal review.

Finally, we would like to thank and acknowledge the Dutch Ministry of Agriculture, Nature and Food Quality, and in particular the Directorate of Fisheries and the Directorate of Nature \& Biodiversity for providing the funding for this project. The project was initiated by Henk Offringa. Kees Verbogt then served as our primary contact person throughout the project and we would like to thank him for his support and advice. We would also like to thank Jeroen Vis and Anne-Marie Svoboda for their helpful comments on a draft version of this report. 


\section{Quality Assurance}

Wageningen Marine Research utilises an ISO 9001:2015 certified quality management system. This certificate is valid until 15 December 2021. The organisation has been certified since 27 February 2001. The certification was issued by DNV GL.

Furthermore, the chemical laboratory at IJmuiden has NEN-EN-ISO/IEC 17025:2005 accreditation for test laboratories with number L097. This accreditation is valid until $1^{\text {th }}$ of April 2021 and was first issued on 27 March 1997. Accreditation was granted by the Council for Accreditation. The chemical laboratory at IJmuiden has thus demonstrated its ability to provide valid results according a technically competent manner and to work according to the ISO 17025 standard. The scope (L097) of de accredited analytical methods can be found at the website of the Council for Accreditation (www.rva.nl).

On the basis of this accreditation, the quality characteristic $Q$ is awarded to the results of those components which are incorporated in the scope, provided they comply with all quality requirements. The quality characteristic $Q$ is stated in the tables with the results. If, the quality characteristic $Q$ is not mentioned, the reason why is explained.

The quality of the test methods is ensured in various ways. The accuracy of the analysis is regularly assessed by participation in inter-laboratory performance studies including those organized by QUASIMEME. If no inter-laboratory study is available, a second-level control is performed. In addition, a first-level control is performed for each series of measurements.

In addition to the line controls the following general quality controls are carried out:

- Blank research.

- Recovery.

- Internal standard

- Injection standard.

- Sensitivity.

The above controls are described in Wageningen Marine Research working instruction ISW 2.10.2.105. If desired, information regarding the performance characteristics of the analytical methods is available at the chemical laboratory at IJmuiden.

If the quality cannot be guaranteed, appropriate measures are taken. 


\section{References}

ASCOBANS (2006) Resolution No. 5 Incidental take of small cetaceans. 5th Meeting of the Parties to ASCOBANS, The Netherlands 18-20 September and 12 December 2006.

http://www.ascobans.org/sites/default/files/document/MOP5_2006-5_IncidentalTake_1.pdf

ASCOBANS (2015) Report of the ASCOBANS Workshop on the Further Development of Management Procedures for Defining the Threshold of 'Unacceptable Interactions' - Part I: Developing a Shared Understanding on the Use of Thresholds/Environmental Limits. London, United Kingdom, 10 July 2015. Available at www.ascobans.org

ASCOBANS (2016) Resolution No.5 Monitoring and mitigation of small cetacean bycatch. 8th Meeting of the Parties to ASCOBANS, Helsinki, Finland, 30 August - 1 September 2016.

http://www.ascobans.org/sites/default/files/document/MOP8_2016-5_Bycatch.pdf

Benoît, HP and Allard, J (2009) Can the data from at-sea observer surveys be used to make general inferences about catch composition and discards? Canadian Journal of Fisheries and Aquatic Sciences 66, 2025-2039.

Bijsterbosch, M and Hermus, M (2014) A peek into harbour porpoise strandings. Necropsy findings of Dutch stranded harbour porpoises (Phocoena phocoena) in periods of high stranding frequency. Van Hall Larenstein, University of Applied Sciences Leeuwarden. Thesis available at:

http://www.samhao.nl/webopac/MetaDataEditDownload.csp?file=2:125122:1

Bouveroux, T, Kiszka, JJ, Heithaus, MR, Jauniaux, T and Pezeril, S (2014) Direct evidence for gray seal (Halichoerus grypus) predation and scavenging on harbor porpoises (Phocoena phocoena). Mar.

Mamm. Sci. 30, 1542-1548 (doi:10.1111/mms.12111)

Bravington, MV and Bisack, KD (1996) Estimates of harbour porpoise bycatch in the Gulf of Maine sink gillnet fishery, 1990-1993. Rep. int. Whal. Commn 46:567-74.

Brown, J, Macfadyen, G, Huntington, T, Magnus, J and Tumilty, J (2005) Ghost Fishing by Lost Fishing Gear. Final Report to DG Fisheries and Maritime Affairs of the European Commission. Fish/2004/20. Institute for European Environmental Policy / Poseidon Aquatic Resource Management Ltd joint report.

Buckland, ST, Anderson, DR, Burnham, KP, Laake, JL, Borchers, DL and Thomas, L (2001) Introduction to Distance Sampling, Oxford University Press, Oxford.

Camphuysen, CJ (2004) The return of the harbour porpoise (Phocoena phocoena) in Dutch coastal waters. Lutra, 47 (2): 113-122

Camphuysen, KCJ, Smeenk, C, Addink, M, van Grouw, H and Jansen, OE (2008) Cetaceans stranded in the Netherlands from 1998 to 2007. Lutra, 51(2):87-122.

Camphuysen, CJ and Siemensma, ML (2011) Conservation plan for the Harbour Porpoise Phocoena phocoena in The Netherlands: towards a favourable conservation status. NIOZ Report 2011-07, Royal Netherlands Institute for Sea Research, Texel.

Camphuysen, KCJ (2011) Recent trends and spatial patterns in nearshore sightings of harbour porpoises (Phocoena phocoena) in the Netherlands (Southern Bight, North Sea), 1990-2010. Lutra, 54(1):39-47.

Couperus, AS, Aarts, G, van Giels, J, de Haan, D and van Keeken, O (2009) Onderzoek naar bijvangst bruinvissen in de Nederlandse visserij. pp. 90. IMARES, IJmuiden. 
Cox, TM, Read AJ, Solow, A and Tregenza, N (2001) Will harbour porpoises (Phocoena phocoena) habituate to pingers? Journal of Cetacean Research and Management, 3:81-86.

Culik, B, von Dorrien, C and Conrad, M (2016) Porpoise Alerting Device (PAL): synthetic harbour porpoise (Phocoena phocoena) communication signals influence behaviour and reduce by-catch. BfN Skripten, 451, 150-155. Retrieved from

https://www.bfn.de/fileadmin/BfN/service/Dokumente/skripten/Skript451.pdf.

FAO/RAP/FIPL (2004) A research agenda for small-scale fisheries. FAO Regional Office for Asia and the Pacific, Bangkok, Thailand. RAP PUBLICATION No. 2004/21 and FIPL/C 10009 (En) 42 pp.

Geelhoed, SCV, Scheidat, M, van Bemmelen, RSA and Aarts, G (2013) Abundance of harbour porpoises Phocoena phocoena on the Dutch Continental Shelf, Aerial Surveys in July 2010 - March 2011. Lutra 56(1):45-57.

Geelhoed, SCV, Lagerveld, S, Verdaat, JP and Scheidat, M (2014) Marine mammal surveys in Dutch waters in 2014. IMARES Report number C180/14.

Geelhoed, SCV, Lagerveld, S and Verdaat, JP (2015) Marine mammal surveys in Dutch North Sea waters in 2015. IMARES WAGENINGEN UR, Institute for Marine Resources \& Ecosystem Studies, Report number C189/15, The Netherlands.

Haelters, J, Kerckhof, F, Jauniaux, T and Degraer, S (2012) The grey seal (Halichoerus grypus) as a predator of harbour porpoises (Phocoena phocoena)? Aquatic Mammals 38:343353

Hall, MA (1999) Estimating the ecological impacts of fisheries: what data are needed to estimate bycatches? p.175-184 in Nolan, C.P. (ed.), Proceedings of the International Conference on Integrated Fisheries Monitoring. Sydney, Australia, 1-5 February 1999.

Hammen, vd T and de Graaf, M (2017) Recreational fisheries in the Netherlands: Analyses of the 2015 screening survey, the 2014 - 2015 logbook survey and the 2014 - 2015 Gillnet survey. CVO report number: 17.005. availableavailable at: http://dx.doi.org/10.18174/409681

Hammond, PS, Benke, H, Berggren, P, Borchers, DL, Buckland, ST, Collet, A, Heide-Jørgensen, MP, Heimlich-Boran, S, Hiby, AR, Leopold, MF and Øien, N (1995) Distribution \& abundance of the harbour porpoise \& other small cetaceans in the North Sea \& adjacent waters. Final Report under European Commission, Project LIFE 92-2/UK/027. Sea Mammal Research Unit, Gatty Marine Laboratory, University of St Andrews, Fife, UK.

Hammond, PS, Berggren, P, Benke, H, Borchers, DL, Collet, A, Heide-Jørgensen, MP, Heimlich, S, Hiby, AR, Leopold, MF, and Øien, N (2002) Abundance of the harbour porpoise and other cetaceans in the North Sea and adjacent waters. Journal of Applied Ecology, 39:361-376.

Hammond, PS, MacLeod, K, Berggren, P, Borchers, DL, Burt, ML, Cañadas, A, Desportes, G, Donovan, GP, Gilles, A, Gillespie, D, Gordon, J, Hiby, L, Kuklik, I, Leaper, R, Lehnert, K, Leopold, M, Lovell, P, Øien, N, Paxton, CGM, Ridoux, V, Rogan, E, Samarra, F, Scheidat, M, Sequeira, M, Siebert, U, Skov, H, Swift, R, Tasker, ML, Teilmann, J, Van Canneyt, O and Vázquez, JA (2013) Cetacean abundance and distribution in European Atlantic shelf waters to inform conservation and management. Biological Conservation 164:107-122.

Hammond, PS, Lacey, C, Gilles, A, Viquerat, S, Börjesson, P, Herr, H, Macleod, K, Ridoux, V, Santos, MB, Scheidat, M, Teilmann, J, Vingada, J and Øien, N (2017) Estimates of cetacean abundance in European Atlantic waters in summer 2016 from the SCANS-III aerial and shipboard surveys. Final Report available at https://synergy.st-andrews.ac.uk/scans3/files/2017/05/SCANS-III-design-basedestimates-2017-05-12-final-revised.pdf 
Hansson S and Rudstam LG (1995) Gillnet catches as an estimate of fish abundance: a comparison between vertical gillnet catches and hydroacoustic abundances of Baltic Sea herring (Clupea harengus) and sprat (Sprattus sprattus). Can. J. Fish. Aquat. Sci., 52(1): 75-83.

Helmond, van, ATM and Couperus, AS (2012) Elektronische monitoring van kleinschalige staandwantvisserij. IMARES rapport C034.12:25 pp.

Herr, H, Fock, HO and Siebert, U (2009) Spatio-temporal associations between Harbour porpoise (Phocoena phocoena) and specific fisheries in the German Bight. Biol Conserv 142: 2962-72.

ICES (2016) Working Group on Bycatch of Protected Species (WGBYC), 1-5 February 2016, ICES HQ, Copenhagen, Denmark. ICES CM 2016/ACOM:27. 82 pp.

ICES (2017a) Report of the Working Group on Bycatch of Protected Species (WGBYC), 12-15 June 2017, Woods Hole, Massachusetts, USA. ICES CM 2017/ACOM:24. 82 pp.

ICES (2017b) Report of the Working Group on Marine Mammal Ecology (WGMME), 6-9 February 2017, St Andrews, Scotland, UK. ICES CM 2017/ACOM:27. 102 pp.

ICES (2018) ICES Advice on fishing opportunities, catch, and effort - Greater North Sea Ecoregion Published 29 June 2018, cod.27.47d20, https://doi.org/10.17895/ices.pub.4436.

IJsseldijk, LL, Kik, MJL and Gröne, A (2018) Post-mortem research on porpoises (Phocoena phocoena) from Dutch waters, 2017. Biological data, health status and causes of death. Statutory Research Tasks Unit for Nature \& the Environment (WOT Natuur \& Milieu), WOt-technical report 116.50 p.; 10 Figs; 5 Tabs; 44 Refs; 2 Annexes. [in Dutch]. Available at: http://edepot.wur.nl/444227

Jefferson, TA and Curry, BE (1994) A global review of porpoise (Cetacea: Phocoenidae) mortality in gillnets. Biological Conservation, 67: 167-183.

Kindt-Larsen, L, Dalskov, J, Stage, B and Larsen, F (2012a) Observing incidental harbour porpoise Phocoena phocoena bycatch by remote electronic monitoring. Endang Species Res 19:75-83

Kindt-Larsen, L, Larsen, F, Stage, B and Dalskov, J (2012b) Fully documented fishery onboard gillnet vessels $<15 \mathrm{~m}$. FINAL REPORT. National Institute of Aquatic Resources Technical University of Denmark. February 2012.

Komoroske, LM and Lewison, RL (2015) Addressing fisheries bycatch in a changing world. Front. Mar. Sci. 2:83. doi: 10.3389/fmars.2015.00083

Koschinski, S, Culik, BM, Trippel, EA and Ginzkey, L (2006) Behavioral reactions of free-ranging harbor porpoises (Phocoena phocoena) encountering standard nylon and BaSO4 mesh gillnets and warning sound. Marine Ecology Progess Series, 313: 285 -294

Kraus, SD, Read, AJ, Solow, A, Baldwin, K, Spradlin, T, Anderson, E and Williamson, J (1997) Acoustic alarms reduce porpoise mortality. Nature 388:525.

Larsen, F, Vinther, M and Krog, C (2002) Use of pingers in the Danish North Sea wreck net fishery. SC/54/SM32. International Whaling Commission, Cambridge, UK. Rep. Int. Whal. Comm. 8 pp

Larsen, F and Eigaard, OR (2014) Acoustic alarms reduce bycatch of harbour porpoises in Danish North Sea gillnet fisheries. Fisheries Research 153:108-112.

Last, v d, N (2011) The impacts of ghost fishing in the Dutch North Sea: An introduction of the scale of the problem and proposed management strategies. Final internship report. Date of publication: 31 
12 2011. Available at: http://www.duikdenoordzeeschoon.nl/wp-content/uploads/Niels-van-der-LastThe-impacts-of-ghost-fishing-in-the-Dutch-North-Sea.pdf

Leopold, MF, Begeman, L, van Bleijswijk, JDL, IJsseldijk, LL, Witte, HJ and Gröne, A (2015) Exposing the grey seal as a major predator of harbour porpoises. Proc. R. Soc. B282:

20142429.http://dx.doi.org/10.1098/rspb.2014.2429

Macfadyen, G, Huntington, T and Cappell, R (2009) Abandoned, lost or otherwise discarded fishing gear. UNEP Regional Seas Reports and Studies, No. 185; FAO Fisheries and Aquaculture Technical Paper, No. 523. Rome, UNEP/FAO. 115p.

Minns, CK and Hurley, DA (1988) Effects of net length and set time on fish catches in gill nets. North Am. J. Fish. Manage., 8:216-223

Ministerie van EZ (2013): Enquête behorend bij de brief van 29 maart 2013, kenmerk DAD/13053186.

Moreno, P, Benke, H and Lutter, S (1993) Behaviour of harbour porpoise (Phocoena phocoena) carcasses in the German Bight: surfacing rate, decomposition and drift routes. In: Bohlken $\mathrm{H}$, Benke $\mathrm{H}$, Wulf J (eds) Untersuchungen über Bestand, Gesundheitszustand und Wanderung der Kleinwalpopulationen (Cetacea) in deutschen Gewässern. FKZ 10805017/11. BMU-Final Report. Institut für Haustierkunde, University of Kiel, Germany.

Northridge, SP and Fortuna, C (2008) Draft Protocol for data collection on bycatch and depredation In the ACCOBAMS Region. A Standardised Methodology for Use in the Collection of Data on Cetacean Bycatch and Depredation of Nets. International workshop on bycatch within the ACCOBAMS area. Rome (FAO HQs), Italy, 17-18 September 2008.

Northridge, SP (1996) A review of marine mammal bycatch observer schemes with recommendations for best practice. Joint Nature Conservation Committee Report No. 219.

O'Keefe, CE, Cadrin, SX and Stokesbury, KDE (2013) Evaluating effectiveness of time/area closures, quotas/caps, and fleet communications to reduce fisheries bycatch. ICES J. Mar. Sci. 71, 1286-1297. doi: $10.1093 /$ icesjms/fst063

Palka, DL, Rossman, MC, Vanatten, AS and Orphanides CD (2008) Effect of pingers on harbour porpoise (Phocoena phocoena) bycatch in the US Northeast gillnet fishery. J Cetacean Res Manag 10: 217-226

Peltier, H, Baagøe, HJ, Camphuysen, KCJ, Czeck, R, Dabin, W, Daniel, P, Deaville, R, Haelters, J, Jauniaux, T, Jensen, LF, Jepson, PD, Keijl, GO, Siebert, U, Van Canneyt, O and Ridoux, V (2013) The Stranding Anomaly as Population Indicator: The Case of Harbour Porpoise Phocoena phocoena in North-Western Europe. PLoS ONE 8(4):e62180. doi:10.1371/journal.pone.0062180

Peltier, H, Authier, M, Deaville, R, Dabin, W, Jepson, PD, van Canneyt, O, Daniel, P and Ridoux, V (2016) Small cetacean bycatch as estimated from stranding schemes: The common dolphin case in the Northeast Atlantic. Environmental Science and Policy, 63:7-18.

Prchalová, M, Mrkvička, T, Peterka, J, Čech, M, Berec, L and J Kubečka (2011) A model of gillnet catch in relation to the catchable biomass, saturation, soak time and sampling period. Fish. Res., 107:201-209

Punt, AE and Donovan GP (2007) Developing Management Procedures That Are Robust to Uncertainty: Lessons from the International Whaling Commission," ICES Journal of Marine Science 64(4):603-612

Rao, PSRS (2000) Sampling methodologies with applications. Chapman and Hall/CRC. New York. 
Read, AJ (2000) Potential Mitigation Measures for Reducing the By-catches of Small Cetaceans in ASCOBANS Waters. Report to ASCOBANS.

Read, AJ, Drinker, P and Northridge, S (2006) Bycatch of marine mammals in US and global fisheries. Conserv. Biol. 20, 163-169. doi: 10.1111/j.1523-1739.2006.00338.x

Reeves, RR, McClellan, $\mathrm{K}$ and Werner, TB (2013) Marine mammal bycatch in gillnet and other entangling net fisheries, 1990 to 2011. Endangered Species Research 20:71-97

Revill, AS and Dunlin, G (2003) The fishing capacity of gillnets lost on wrecks and on open ground in UK coastal waters. Fisheries Research, 64(2-3):107-113.

Roe, WD, Gartrell, BD and Hunter, SA (2012) Freezing and thawing of pinniped carcasses results in artefacts that resemble traumatic lesions. The Veterinary Journal, 194:326-331.

Saila, S (1983) Importance and assessment of discards in commercial fisheries. UN/FAO, Rome, Italy. FAO Circ. 765. 62 pp.

Scheidat, M, Leaper, R, van den Heuvel-Greve, M and Winship, A (2013) Setting Maximum Mortality Limits for Harbour Porpoises in Dutch Waters to Achieve Conservation Objectives. Open Journal of Marine Science, 03: 133

Scheidat, M (2015) 2014 Annual National Report: Netherlands. ASCOBANS Advisory Committee Meeting AC22/Inf.15.1.g. The Hague, Netherlands, 29 September - 1 October 2015 Dist. 3 August 2015 Available at:

http://www.ascobans.org/sites/default/files/document/AC22_Inf_15.1.g_NationalReport_Netherlands. pdf

Scheidat, M and Königson S (2016) Workshop on Remote Electronic Monitoring with Regards to Bycatch of Small Cetaceans. The Hague, Netherlands, 2 October 2015. Available at: http://www.ascobans.org/sites/default/files/document/ASCOBANS_WS_REM_2015_Report.pdf

Scheidat, M, Bos, O and Geelhoed, SCV (2016) The feasibility of tagging harbour porpoises in Dutch waters. IMARES Report [C009/16].

Siemensma, ML (2014) Bijvangstmitigatie Bruinvis. Final report of the European Fisheries Fund porpoise bycatch mitigation trial by Vereniging Kust \& Zee.

Staatscourant (2012) Regeling van de Staatssecretaris van Economische Zaken, Landbouw en Innovatie van 27 Juni 2012, nr. 268070, houdende wijzing van de Uitvoeringsregeling visserij ten behoeve van het onder voorwaarden toestaan van recreatief gebruik van staand want in de Visserijzone.

Trippel, EA, Holy, NL, Palka, DL, Shepard, TD, Melvin, GD and Terhune, JM (2003) Nylon barium sulphate gillnet reduces porpoise and seabird mortality. Marine Mammal Science, 19:240-243.

Vinther, M (1999) Bycatches of harbour porpoises Phocoena phocoena in Danish set-net fisheries. J Cetacean Res Manag 1:123-135

Vinther, M and Larsen, F (2004) Updated estimates of harbour porpoise bycatch in the Danish bottom set gillnet fishery. J Cetacean Res Manag 6:19-24

Weel, SMH (2016) Investigating feeding behaviour of harbour porpoise (Phocoena phocoena) using stationary passive acoustic data (C-POD). M.Sc. Thesis AEW-80430 Aquatic Ecology and Water Quality Management Group Wageningen University. Report No. 2016 M10. 


\section{Justification}

Report C102/18

Project Number: 4308601077

The scientific quality of this report has been peer reviewed by a colleague scientist and a member of the Management Team of Wageningen Marine Research

Approved: $\quad$ Edwin van Helmond

Researcher

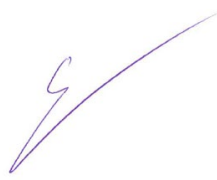

Signature:

Date: 18 December 2018

Approved: $\quad$ Drs. J. Asjes

Manager integration

Signature:

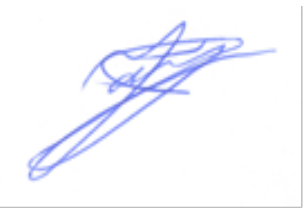

Date: 18 December 2018 


\section{Annex I - Vessel selection}

In 2013 the selection of the initially participating vessels took place. The aim was to ensure that the sample fleet was as similar as possible to the overall fleet, taking into consideration that a completely random sampling would not be possible. An in-depth analyses was done using the historic fishing data from 2008 to 2012 and more specifically for the year 2012/2013. The results were presented as interim reports to the ministry. Here we provide a summary of the process.

\section{Selection was based on a number of criteria:}

\section{fishing effort:}

Although over 100 Dutch vessels are registered in the set net fishery, a large proportion is only operating for several days per year. Vessels that had less than 20 fishing days per year activity, or had stopped fishing activity in the year 2012 were considered not suitable for the selection. Of a total number of 209 vessels, 77 vessels remained to be active enough for the selection.

size:

The presence of a structure on board to place the camera and a dry area to store the computer was also an exclusion criteria. If the vessel was too small (generally under $7 \mathrm{~m}$ ) and thus did not have a frame to place the camera, and/or if it did not have a dry area, installation of the REM system was not possible.

catches:

The selected vessels in total should cover between 5 and $10 \%$ of the overall fleet effort. This should include fishing days, but also tons of fish landed.

spatial coverage:

Some areas were not used frequently by the overall fleet, so it was important to investigate if some of the selected vessels would be in those areas. This was done by analysing the activity of the proposed vessels for the relevant ICES areas.

\section{seasonal coverage:}

The use of either single-walled gillnets or trammel nets is highly linked to seasonality. It was important to make sure that the vessels that were short-listed would also be active in winter as this is the trammel net fishery which was suspected to have most if not all bycatches. As this covers only has a very small proportion of the active fleet, the selection of winter fishing days was a priority.

net coverage:

Both single-walled gillnets (GNS) and trammel nets (GTR) should be covered. It was suspected that most if not all bycatch would occur in GTR nets.

wreck fishery:

This is a specific fishery conducted around wrecks, generally with larger vessels but nets no longer than $400 \mathrm{~m}$. This is not a well-documented type of fishery, the information on this fishing activity was obtained through a questionnaire. Vessels that conducted wreck fishery were prioritized in the selection.

A decision tree was applied to come up with a first selection of potential vessels. Because for some regions fishing effort was always low, in those cases regional coverage was considered a higher priority than minimum fishing activity. The Kenniskring Staandwant visserij (Dutch Fisheries Expert Group on gillnet fisheries) checked the resulting short-listed selection of vessels we obtained from the database to ensure the data was correct. Based on this information these potential vessels were ranked.

The final selection of vessels was done in consultation with the "Kenniskring Staandwant visserij" (Dutch Fisheries Expert Group on gillnet fisheries) and the Dutch Fishermen's Association 
(Nederlandse Vissersbond), VisNed and the Ministry of EZ. All participation for this project was on a voluntary basis. After the first selection had been confirmed, unfortunately an unexpected last minute change in vessel participation changed the expected coverage. This resulted in a new analyses to evaluate if the new selection could still be considered representative.

The new evaluation showed that, based on the historical data, the seasonal coverage as well as the coverage of gear type and target species was well represented by the selected vessels for both types of fishery (gillnet \& trammel net). The selected vessels would have covered well over $10 \%$ of all fishery activity, seasonal activity, all gear types and target species. With the assumption that the future fishing effort would be similar to the years 2010 to 2012, the predicted effort of our sample fleet would be in our target range of 5 to $10 \%$.

As this analysis shows data that was collected several years ago, it can only be an approximation of what can be expected. Fishing effort changes continuously, and it is not predictable how it will develop in the following years. After the project had finalized an analyses was conducted to investigate if the actually selected vessels were an approximate representation of the overall fleet behaviour for the study period (see Annex II). 


\section{Annex II - Activity of sample fleet vs entire fleet}

In this study an ad-hoc selection (see Annex I) was used to determine which vessels to participate in the REM program. We conducted an analyses once the data collection was finalized to see if the initial criteria used to select the sample fleet were indeed providing us with a data set that was similar in fishing behaviour to the entire fleet. Note that this comparison includes the overall fishing effort of the sample fleet, not the effort analysed. The parameters we compared were: vessel length, areas fished, average landed fish per fishing day and seasonal activity in fishing days. The dataset is from 1 . June 2013 to 31. March 2017.

\section{Vessel length}

The sample fleet average length of vessels is the same as for the overall fleet. However, it the range more restricted, not including any vessels in size less than $5 \mathrm{~m}$ or more than $15 \mathrm{~m}$ in length.

Table II.1: Vessel length $(m)$ for entire Dutch gillnet fleet and sampled gillnet fleet (time period 1. June 2013 to 31. March 2017)

\begin{tabular}{cccccc}
\hline & $\begin{array}{c}\text { Number of } \\
\text { vessels }\end{array}$ & $\begin{array}{c}\text { Minimum } \\
\text { length } \\
(\mathrm{m})\end{array}$ & $\begin{array}{c}\text { Maximum } \\
\text { length } \\
(\mathrm{m})\end{array}$ & $\begin{array}{c}\text { Mean } \\
\text { length } \\
(\mathrm{m})\end{array}$ & $\begin{array}{c}\text { Std. } \\
\text { deviation }\end{array}$ \\
\hline Entire fleet & 123 & 2.60 & 24.12 & 9.17 & 4.78 \\
\hline Sampled fleet & 13 & 5.46 & 14.54 & 10.09 & 2.47 \\
\hline
\end{tabular}

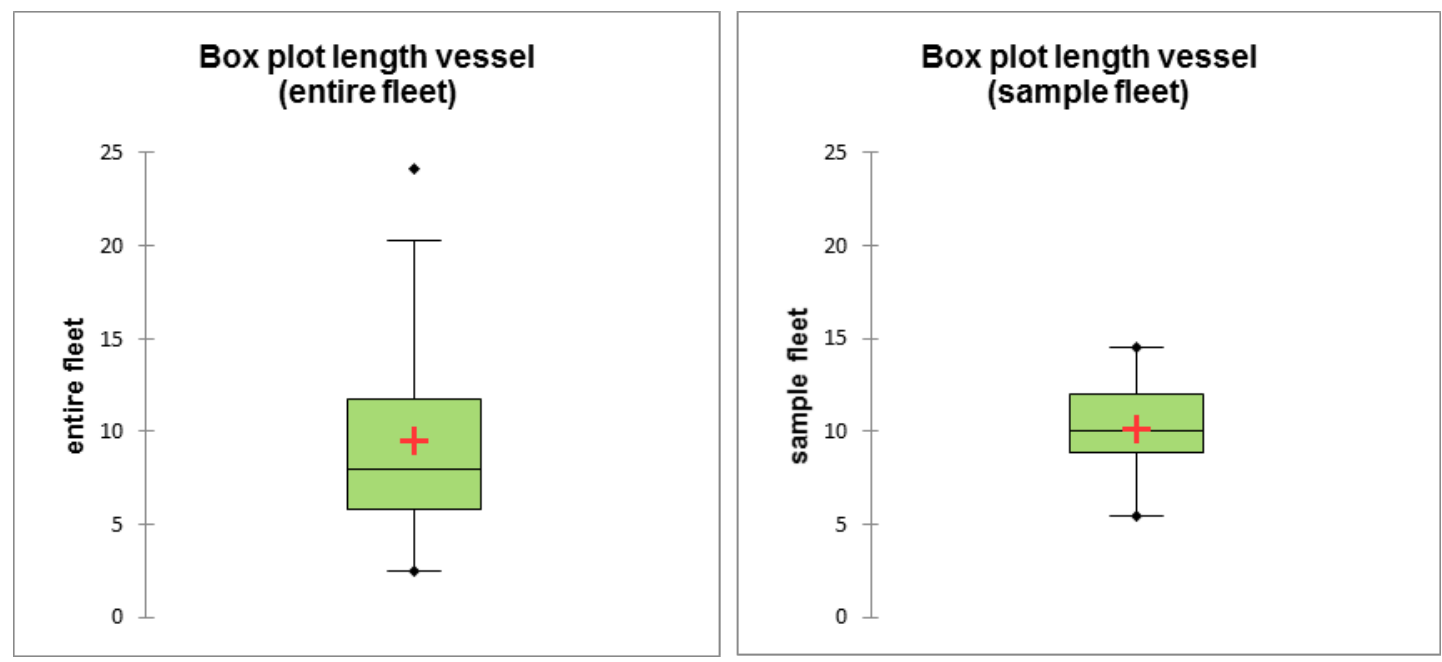

Figure II.1 Distribution of vessel lengths of the entire fleet vs the sample fleet. 

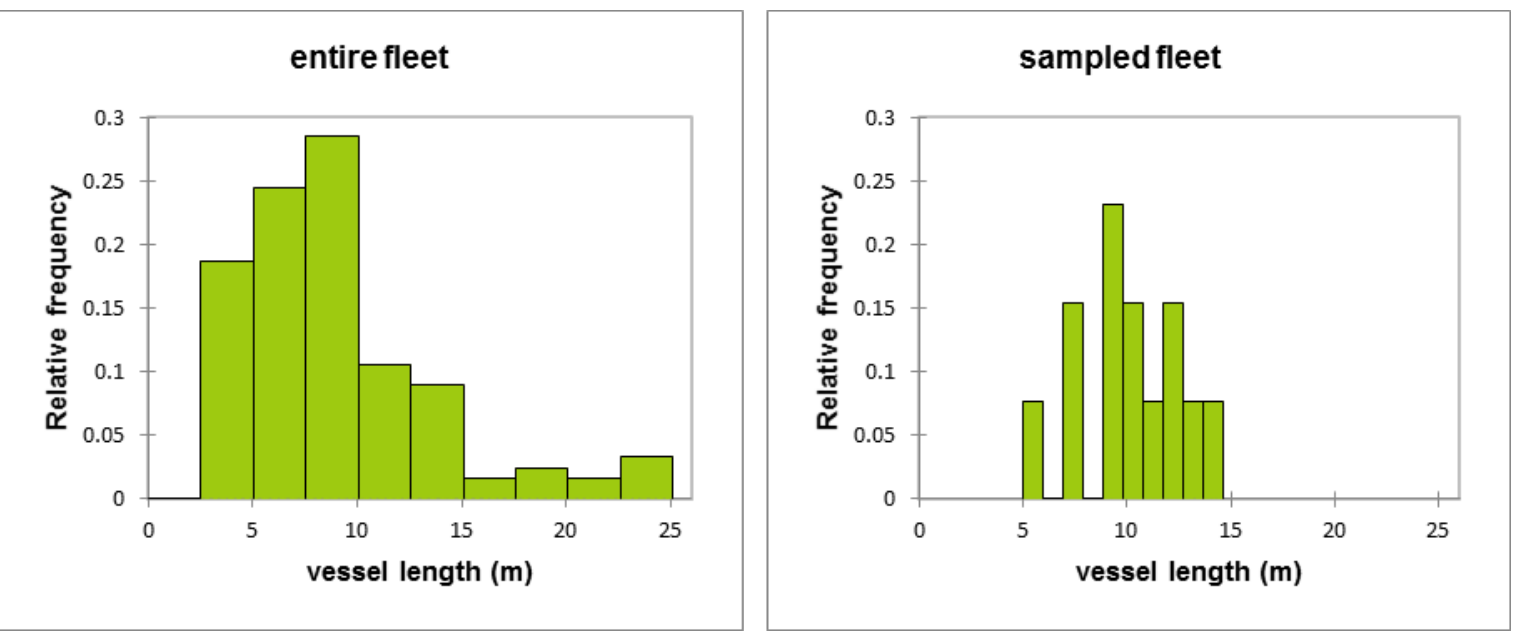

Figure II.2: Histogram of vessel length distribution of the Dutch gillnet fleet and the sampled fleet (time period 1. June 2013 to 31. March 2017)

\section{Areas fished}

Fishing effort of the Dutch gillnet fleet (at sea) took place in 24 ICES quadrants during the study period. Almost all effort took place in nine ICES quadrants (31F2, 31F3, 32F3, 32F4, 33F3, 33F4, 34F3, 34F4, 35F4, 35F5, 36F5), with $98.4 \%$ of effort for the entire fleet and $99.9 \%$ for the sample fleet occurring here. The rest of the fishing effort was distributed over the remaining 15 ICES squares. On average these have had 2.6 fishing days per quadrant per year in the study period per quadrant. See figures $8,9,10$ and 11 in this report for the location of the quadrants.

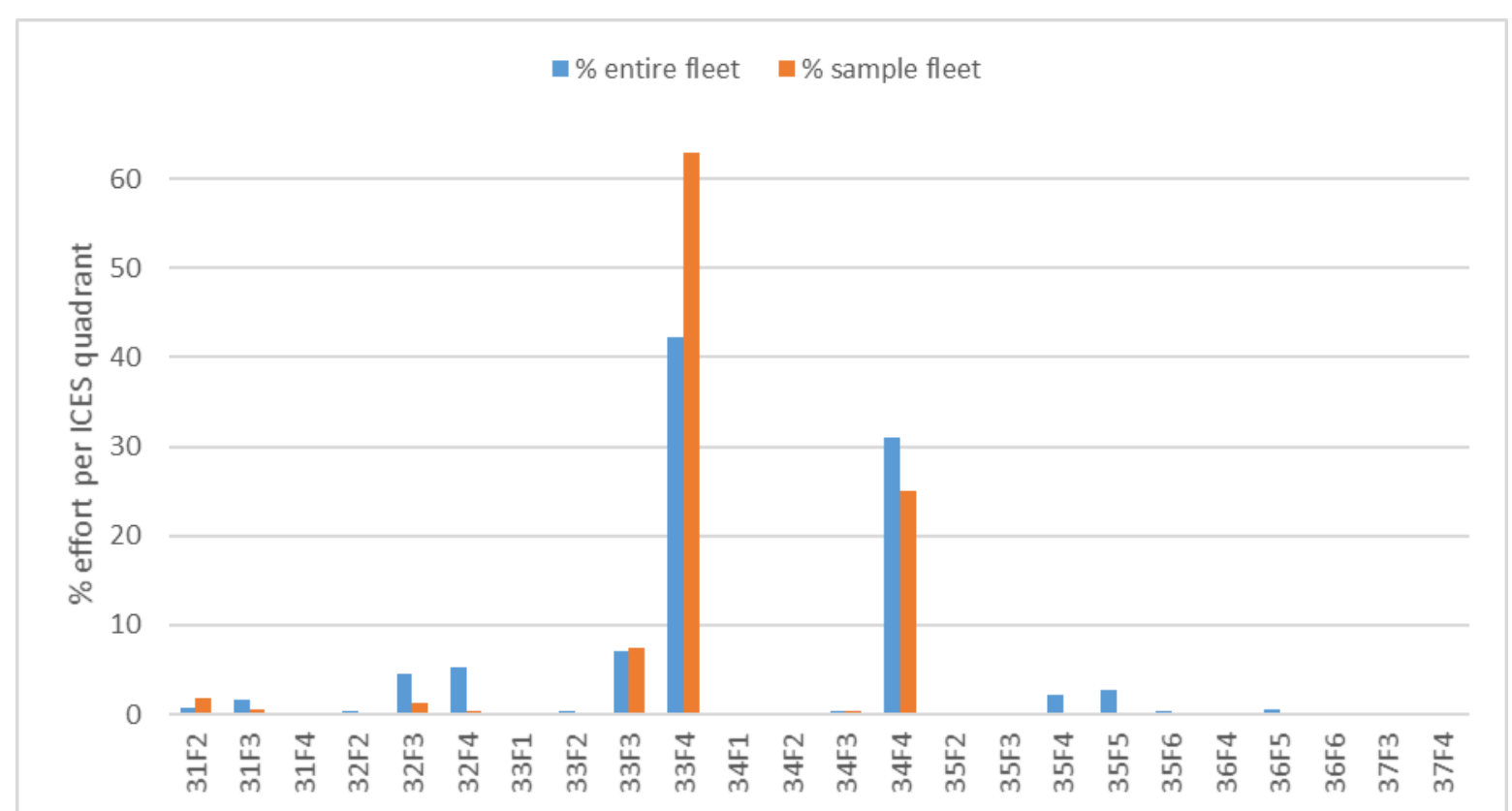

Figure II.3. Comparison of fishing activities of the complete fleet and the sample fleet expressed as \% fishing days per ICES 1/9th quadrant for the study period (1. June 2013 to 31. March 2017). 


\section{Landed fish (kg) per day}

Both sample fleet and overall fleet have a very similar distribution of kg landed fish per day. The average catch is higher for the sample fleet.
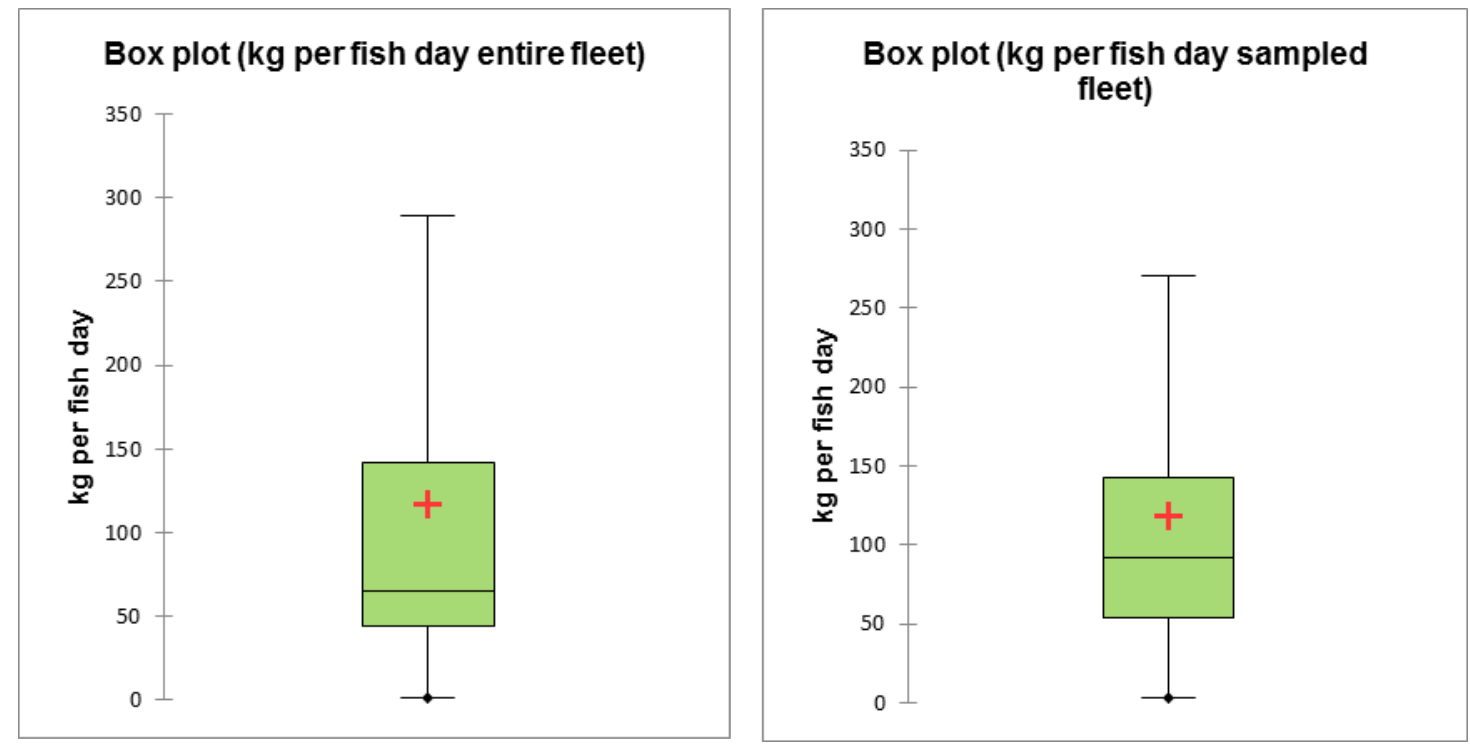

Figure II.4. Comparison of the $\mathrm{kg}$ landed fish for the complete fleet and the sample fleet. Data is presented for both single-walled gillnets (GN) and trammel nets (GT) combined.

\section{Seasonality}

Seasonality of fishing activity (expressed as fishing days) is similar between the entire and the sample fleet.

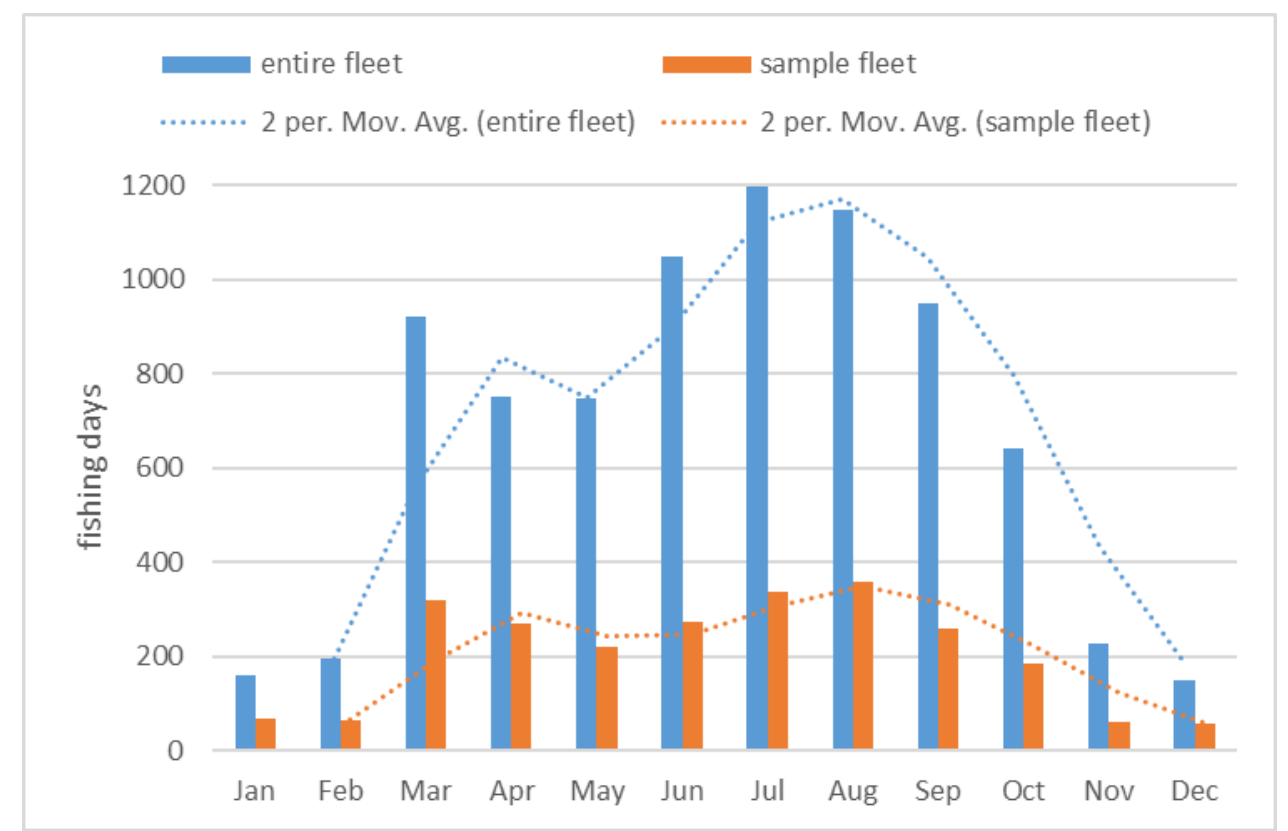

Figure II.5. Total fishing days per month for the study period (1 June 2013 to 31 March 2017) for the entire fleet and the sample fleet. 


\section{Annex II - Outreach and International exchange}

During the project outreach and exchange with stakeholders and international fora took place.

\section{Bruinvisnetwerkdag}

A meeting organised by EZ to inform stakeholders about the progress of this project originally was scheduled for 2014. However, it was decided to organise a meeting at a later stage in the project. In 2015 a harbour porpoise stakeholder meeting was hosted by EZ (15 October 2015), with a focus on progress and the status of the implementation of the conservation plan. At this meeting the project 'Onbedoelde bijvangst in beeld' was briefly presented. Rems Cramer, spokesman of the participating fishermen, and also participating fisherman, informed the participants on the aim of the project. A brief video fragment was presented in which a Danish colleague had a harbour porpoise bycatch. He referred to some bottle-necks and success factors of the project. He emphasized the importance of a good dialogue with the fishermen and an intermediate with the ability to project into the situation of the sector and to level between all parties involved. No preliminary results were mentioned, to prevent speculation potentially leading to miscommunication. However it mentioned that until October 2015 results so far do not appear to deviate from expected bycatches from the sector.

\section{ASCOBANS Advisory Committee and ICES Bycatch working group}

At the annual Advisory Committee meeting of ASCOBANS in 2013, 2014, 2015, 2017 and 2018 the project outline was mentioned as well as at the annual ICES working group on bycatch. This ICES working group provides a good network of other institutes working with similar EM monitoring projects, to exchange experiences and to gain advice on several issues such as installation and data analysis.

\section{ASCOBANS REM workshop}

In The Hague on 2 October 2015 a workshop on Remote Electronic Monitoring (REM) with regards to bycatch of small cetaceans was organized by ASCOBANS and chaired by Meike Scheidat and Sara Königson. The aim of this workshop was to discuss the current status, potential shortcomings and new developments of REM techniques that could be used to help improve cetacean bycatch monitoring. The main topics discussed were stakeholder involvement, statistical survey design and data collection and analysis. A presentation on stakeholder involvement based on the Dutch EM project was given by Marije Siemensma (MS\&C).

One of the main conclusions of the workshop was that from a technical perspective REM could be used successfully to monitor small cetacean bycatch, but decisions whether REM was the best and most cost-effective option would depend on the specific situation. This was influenced by the type of monitoring being conducted, the fishing fleet that was targeted as well as personnel and technical costs which could vary greatly between countries.

The workshop participants concluded that the EU Data Collection Framework (DCF), in its current form, was not adequate for monitoring small cetacean bycatch, mainly because most sampling effort (fleet, gear-type, area) under the DCF was currently targeted at fisheries (mainly demersal trawls) where small cetacean bycatch was not likely to be a major concern. In addition DCF sampling protocols were not designed to quantify the bycatch of large non-commercial species, and in particular those animals that sometimes fell out or were removed from the net outside the vessel. If monitoring bycatch of cetaceans was to be included in the DCF, these shortcomings needed to be addressed. REM techniques and other additional techniques could be a way forward in collecting cetacean bycatch data along with data on commercial catches. A list of best practical advice in the report reflects the outcomes of the workshop. Link to the report: http://www.ascobans.org/en/meeting/WS-REM-2015

\section{EHBZ meeting}

At a meeting at Utrecht University for the EHBZ network in April 2015 the audience was informed by Marije Siemensma (MS\&C) about the bycatch protocol (e.g. choice for the fisherman to label the animal and: a) land or b) drop over board a bycaught (dead) porpoise. The audience, mainly people 
collecting carcasses of both seals and porpoises on the beach, might encounter such a labelled porpoise which was the reason to specifically pay attention to this.

Table III. 1 Overview of the events during the project regarding logistics, communication with the project partners, data collection \& analysis, outreach and (international) exchange.

\begin{tabular}{|c|c|}
\hline \multicolumn{2}{|c|}{ Time line project "Onbedoelde bijvangst in beeld" 2012-2018 } \\
\hline Logistics & time \\
\hline Ordering of EM camera systems at Archipelago & dec-12 \\
\hline Contract with PB for installation and maintenance & dec-12 \\
\hline Meeting with Jaap van der Meer (scientific advisor) on selection of fishermen & jan-13 \\
\hline Preparing of contracts with participating fishermen with EZ & feb-apr 2013 \\
\hline Selection of participating fishermen & feb-13 \\
\hline Sending of contracts with participating fishermen via EZ & may 2013 \\
\hline Installation on four vessels, testing of system, solving of technical problems & jul-13 \\
\hline Installation on 2 more vessels, testing of system, solving technical problems & dec-13 \\
\hline Installing of additional power supplies on some vessels & oct - dec 13, jan 14 \\
\hline Writing of bycatch protocol ("aanlanden of terugzetten") & aug-13 \\
\hline Ordering and sending labels for bycatch & sep-13 \\
\hline Installation of additional power supplies on some vessels & jan-14 \\
\hline $\begin{array}{r}\text { External factor (in short supply of sole quota due to high demand) leading to } \\
\text { unrest with the participating fishermen }\end{array}$ & 2014 \\
\hline $\begin{array}{r}\text { Science quota was requested by participating fishermen, supported by project } \\
\text { team (MS\&C) and granted by EZ for both } 2014,2015 \text { and } 2016\end{array}$ & $2014,2015 \& 2016$ \\
\hline $\begin{array}{r}\text { Project team together with the "Kenniskring Staandwant visserij" and EZ } \\
\text { selected four additional fishermen }\end{array}$ & nov $2014-\operatorname{mar} 2015$ \\
\hline Preparing of contracts with EZ for new participating fishermen & 2015 \\
\hline Sending of contracts to participating fishermen via EZ & 2015 \\
\hline $\begin{array}{r}\text { Installation of Electronic Monitoring (EM) system/camera on six vessels, testing } \\
\text { of system, solving of technical problems }\end{array}$ & $\begin{array}{l}2014,2015,2016 \& \\
2017\end{array}$ \\
\hline De-installation of Electronic Monitoring (EM) system/camera & $2018 / 19$ \\
\hline Communication with project partners & time \\
\hline $\begin{array}{l}\text { Project announcement by the Ministry of EZ at a "Kenniskring Staandwant } \\
\text { visserij" meeting, aiming to get fishermen volunteering to participate }\end{array}$ & 1 -oct-2012 \\
\hline Presentation project at N2000 meeting NL Vissersbond 16 apr 2013 & 16-apr-13 \\
\hline "Startbijeenkomst" with fishermen and EZ & 26-apr-13 \\
\hline Meeting with fishermen that have declined participation (Urk) & oct 2013 \\
\hline Meeting project team with EZ and NL Vissersbond & jan-14 \\
\hline Meeting with EZ and installation company & apr-14 \\
\hline $\begin{array}{r}\text { Workshop for participating fishermen on practical issues and presenting interim } \\
\text { report } 2013\end{array}$ & 11 -jun-14 \\
\hline Interim report presented to fishery representatives for review & feb-14 \\
\hline
\end{tabular}


Time line project "Onbedoelde bijvangst in beeld" 2012-2018

\begin{tabular}{|c|c|}
\hline Update status of project at Kenniskring staandwant d.d. 13 november 2014 & $13-n o v-14$ \\
\hline Evaluation meeting project by Wageningen Economic Research & $15-$ dec-16 \\
\hline Meeting presenting draft results with fishermen's representatives & 02-nov-17 \\
\hline $\begin{array}{r}\text { Meeting with Jaap van der Meer (scientific advisor) on draft results and data } \\
\text { interpretation }\end{array}$ & nov 2017 \\
\hline Meeting presenting draft results to participants & jan/feb 2018 \\
\hline Meetings with EZ, at regular interval contact by phone or email & throughout project \\
\hline $\begin{array}{r}\text { Harbour visits of project team to fishermen (regular interval) and contact by } \\
\text { phone, text message or email }\end{array}$ & throughout project \\
\hline Project team meetings & throughout project \\
\hline Data collection \& analysis & time \\
\hline Start of data collection & jul-13 \\
\hline Continuous data collection & jul 13 - 1st april 17 \\
\hline Training of EM analysis with Archipelago & oct $13-\operatorname{dec} 13$ \\
\hline $\begin{array}{r}\text { Optimizing the format of the results of the analysis program; development of } \\
\text { data analysis protocol }\end{array}$ & 2014,2015 \\
\hline Training of staff for EM analysis (IMARES) & $2014,2015,2016$ \\
\hline $\begin{array}{r}\text { Checking of camera positions by project team and fishermen, analysis of EM } \\
\text { footage (IMARES) }\end{array}$ & dec 2013 - nov 2017 \\
\hline Outreach \& (International) exchange & time \\
\hline reporting on project at ICES Working group on Bycatch of protected species & $2014-2017$ \\
\hline project outlined at Advisory Committee meeting of ASCOBANS $^{2}$ & $\begin{array}{l}2013,2014,2015 \\
2017 \& 2018\end{array}$ \\
\hline $\begin{array}{r}\text { Presentation of the project with focus on stakeholder involvement at ASCOBANS } \\
\text { Remote Electronic Monitoring workshop The Hague }\end{array}$ & oct 2015 \\
\hline $\begin{array}{r}\text { Presentation of the project at the "Bruinvisnetwerkdag", Kasteel Groeneveld } \\
\text { Baarn }\end{array}$ & oct 2015 \\
\hline $\begin{array}{r}\mathrm{EHBZ}^{3} \text { meeting at Utrecht University, on the aim of the project and options for } \\
\text { bycatch handling }\end{array}$ & apr-15 \\
\hline
\end{tabular}

\footnotetext{
${ }^{2}$ ASCOBANS: Agreement on the Conservation of Small Cetaceans in the Baltic, North East Atlantic, Irish and North Seas

${ }^{3}$ EHBZ Eerste Hulp bij Zeezoogdieren
} 


\section{Annex IV - Necropsy results}

Stranded - and necropsied - porpoises are an important source of information of the population of their origin. The necropsy work was not a main aim of this project, however, the information that could be obtained from pathological investigation of the bycaught animals is considered very valuable. Additional funding could be secured to conduct the necropsies and the participating fishermen landed bycaught porpoises whenever possible. Table IV.1 provides an overview of the 8 animals necropsied.

This section can be cited as:

IJsseldijk, L 2018. Case history - Harbour Porpoise Necropsy Results. Annex IV In: Scheidat, M, Couperus, B and Siemensma, ML (2018) Electronic monitoring of incidental bycatch; Wageningen, Wageningen Marine Research (University \& Research centre), Wageningen Marine Research report C102/18.

Table IV.1 UU case number and date of bycatch of the 8 necropsied harbour porpoises by Utrecht University.

\begin{tabular}{|lcccccccc|}
\hline $\begin{array}{l}\text { UU Case } \\
\text { number }\end{array}$ & UT1006 & UT1297 & UT1317 & UT1417 & UT1473 & UT1471 & UT1485 & UT1571 \\
\hline $\begin{array}{l}\text { Date of } \\
\text { bycatch }\end{array}$ & $\begin{array}{c}04-09- \\
2013\end{array}$ & $\begin{array}{c}10-12- \\
2013\end{array}$ & $\begin{array}{c}03-06- \\
2014\end{array}$ & $\begin{array}{c}06-10- \\
2014\end{array}$ & $\begin{array}{c}12-06- \\
2015\end{array}$ & $\begin{array}{r}27-06- \\
2015\end{array}$ & $\begin{array}{c}20-08- \\
2015\end{array}$ & $\begin{array}{c}11-03- \\
2017\end{array}$ \\
\hline
\end{tabular}

\section{Case history - Harbor Porpoise Necropsy Results}

Lonneke L. IJsseldijk

\section{Case UT1471}

Case history This harbor porpoise was found in the fishing nets of one of the REM-project participants on 27-06-2015 and reported. The fisherman brought the animal into the harbor of Scheveningen, where it was picked up and brought to Utrecht. The necropsy was performed at the faculty of Veterinary Medicine on 28-06- 2017.

Macroscopic findings The specimen was a juvenile male of $115 \mathrm{~cm}$ total body length and $24,5 \mathrm{~kg}$ total weight. The main macroscopic findings included:

General observations Multifocal small cuts of approximately $1 \mathrm{~cm}$ on left flank, superficial, affecting only the epidermis. No other abnormalities detected.

Net marks Around tip of rostrum several net imprints with some clear angles were visible. On the cranial end of the fluke, also several net imprints and cuts (Fig. IV.1) were observed, bilateral on dorsal and palmar sides, some ranging in size of 2-3 cm. Less obvious, small and very superficial net marks on dorsal cranial side of the pectoral fins.

Subcutaneous observations and lesions On the scapula of the left pectoral fin, pooling of blood as a dark red area of approx. $8 \mathrm{~cm}$ in diameter is present, interpreted as hemorrhage or blunt force trauma. No other macroscopic changes were detected in subcutaneous tissues and the animal's skeleton.

Abdominal cavity Intestine: Diffusely well filled, enlarged associated mesenteric lymph nodes. Stomachs: Some otoliths and fish eye balls observed but not much; no abnormalities detected. Kidney: The right kidney is misshaped, smaller in size than the left kidney and separated from the right adrenal. No macroscopic changes were detected in other abdominal tissues.

Thorax, head and neck Lungs: Severe alveolar edema and mild parasite infestation, associated pulmonary lymph nodes enlarged. Auditory system: Moderate bilateral parasite infestation. No macroscopic changes were detected in other head, neck and thoracic tissues. 
Summary of main findings histopathology The histopathological examination revealed a mild bronchopneumonia (lung inflammation), partly as a result of the parasite infestation. Additionally, some mild signs of hemochromatosis were detected (stacking of iron) in the liver. All major organs showed moderate to severe hyperemia.

Conclusion Juvenile male in good nutritional body condition with little sign of recent feeding. Net marks prominent on fluke and rostrum, some minor markings on pectoral fins. Enlarged pulmonaryand mesenteric lymph nodes. Deformation of kidney. Histopathological, a parasite associated pneumonia was detected. No abnormalities were found in the kidneys and adrenal, with the exception of hyperemia, which was prominent in all major organs. These findings were consistent with bycatch.

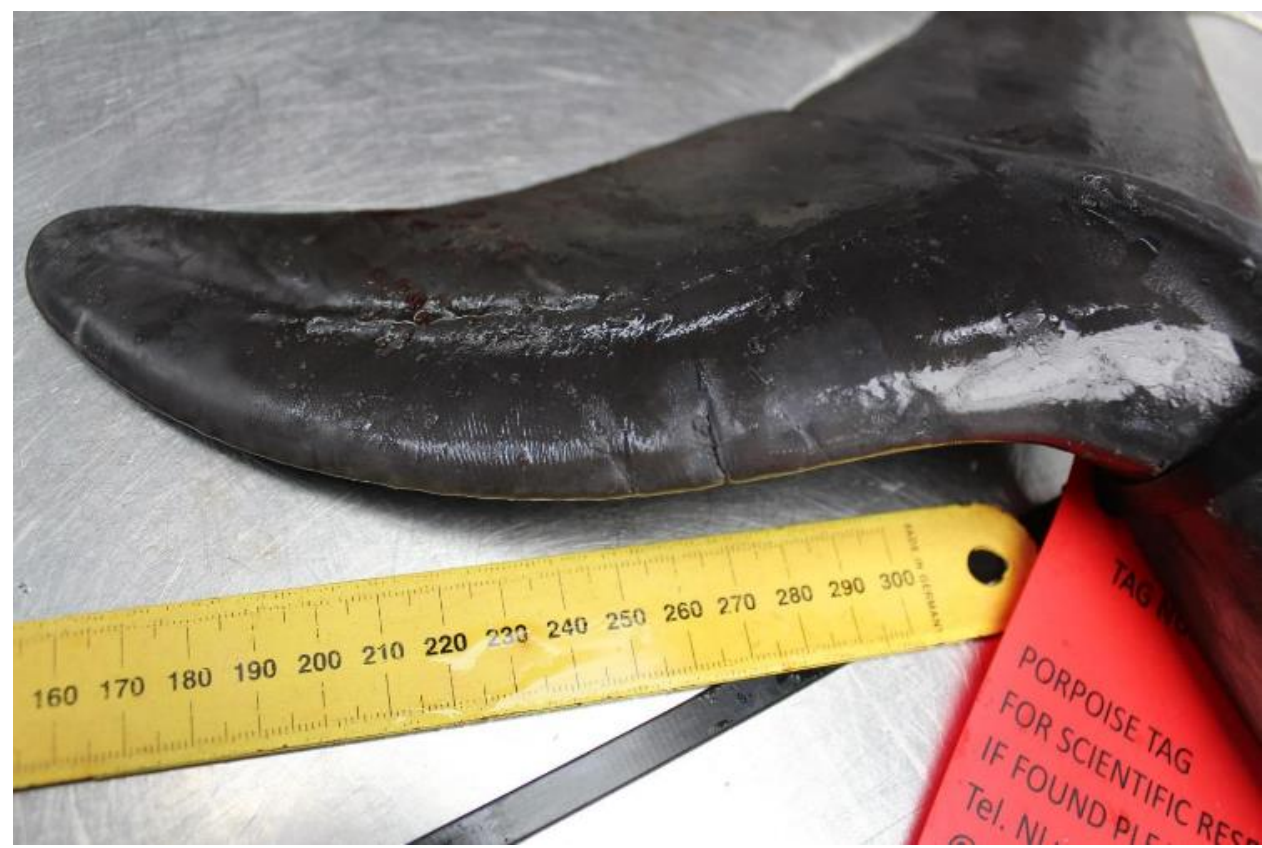

Figure IV.1: Case UT1471 right side fluke with on cranial end several deep, parallel running net imprints. Photo Utrecht University

\section{Case UT1297}

Case history This harbor porpoise was found in the fishing nets of one of the REM-project participants on 10-12-2013 and reported by Bram Couperus. The fisherman brought the animal into the harbor of Scheveningen, where it was picked up by Bram the same evening and brought to Utrecht. The necropsy started at 20:30h at the faculty of Veterinary Medicine.

Macroscopic findings The specimen was a juvenile male of $101,5 \mathrm{~cm}$ total body length and $16,2 \mathrm{~kg}$ total weight. The main macroscopic findings included:

General observations The porpoise had a misshaped dorsal fin with an irregularity on the caudal edge (old lesion) accompanied by several irregular running healed scratches. Multifocal longitudinal scars were also present on the body wall with three running almost parallel, with an interlinear distance of 2 and $1.5 \mathrm{~cm}$. In additional, multifocal half-moon shaped and oval ulcerations and discolorations present with a size of $1-8 \mathrm{~cm}$ in diameter (Fig. 1). On head with black firm of discoloration. On body wall with often hyperplastic pale wound edges (chronic) $\pm 5 \%$ of skin affected.

Net marks Bilaterally in both pectoral fins were cuts present on the caudal edge, with a thin line running towards a small impression in the cranial edge (on the right pectoral fin more clear than left), length/diameter $6 \mathrm{~cm}$.

Subcutaneous observations and lesions The animal was poorly musculated. No macroscopic changes were detected in subcutaneous tissues and the animal's skeleton.

Abdominal cavity Intestine: Segmentally filled. Stomachs: Several small, partly digested fish and otoliths present in first stomach. Other stomach parts seem empty; no abnormalities detected. No macroscopic changes were detected in other abdominal tissues.

Thorax, head and neck Trachea: Mild parasite infestation and approximately 50\% of the trachea was filled with edema. Lungs: Moderate parasite infestation in main bronchi, which was filled for approximately $30 \%$. Bilateral in medial lung lobes firm areas and on cut surface suppurative exudate in the airways. Heart: \pm 7 nematodes in truncus pulmonalis. Esophagus: Ulcerated areas, longitudinal and oval with size of $2 \mathrm{~mm}-3 \mathrm{~cm}$. Auditory system: Severe bilateral parasite infestation. No significant 
macroscopic changes were detected in other head, neck and thoracic tissues.

Summary of main findings histopathology The histopathological examination confirmed that this animal suffered of a chronic, multifocal, ulcerated and suppurative dermatitis (skin inflammation); a severe multifocal granulomatous bronchopneumonia (lung inflammation) with intralesional nematodes; an ulcerated esophagus with mucosal degeneration and necrosis; a chronic hepatitis (liver inflammation) and inflammation of the brain. Sections of the net mark imprints revealed acute hemorrhage.

Conclusion Juvenile male in poor nutritive condition with evidence of recent feeding, moderate dermatitis, esophagus ulcerations, moderate nematode infestation in lungs and moderate pneumonia and alveolar edema, severe nematode infestation in ears, moderate in the heart. Histopathology confirmed dermatitis, pneumonia and esophagitis. In addition, a chronic hepatitis and encephalitis was diagnosed.

Although this animal was able to catch prey, the multiple organ infection could have significantly debilitated this individual, therefore, it can be concluded that this harbor porpoise had a reduced health status at the time it got bycaught.

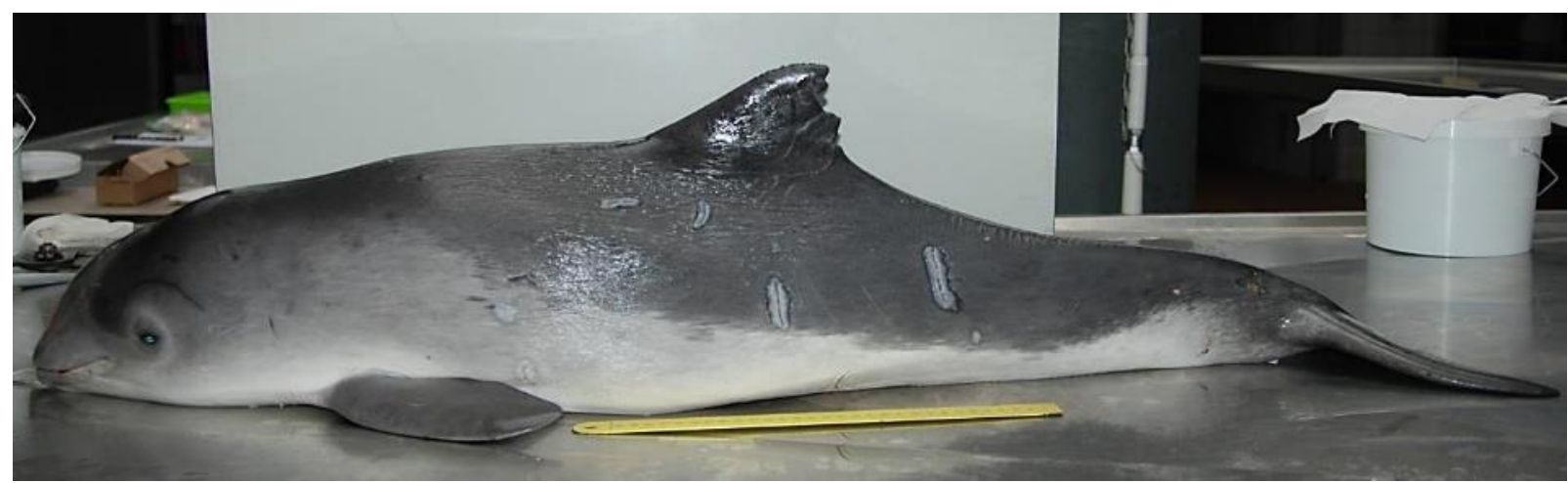

Figure VI.2: Case UT1297 left body side view which shows the multifocal, chronic skin lesions and the misshaped dorsal fin as a result of an old injury. Photo Utrecht University

\section{Case UT1571}

Case history This harbor porpoise was found in the fishing nets of one of the REM-project participants on 11-03-2017 and reported by Marije Siemensma. The fisherman brought the animal into the harbor of Scheveningen, where it was picked up by staff of UU and brought to Utrecht. The necropsy was performed at the faculty of Veterinary Medicine on 13-03-2017.

Macroscopic findings The specimen was a juvenile male of $115 \mathrm{~cm}$ total body length and $28 \mathrm{~kg}$ total weight. The main macroscopic findings included:

General observations Two small injuries on the right side of the head, bleeding. Also, bleeding from oral cavity. Edema protruding from the blowhole. Open mouth, possible as a result of rigor mortis (Fig.VI.3).

Net marks Net marks on rostrum, especially the mandible. On the left pectoral fin, a cut resulted in a loose flap hanging on the caudal end of the fin. Nicks in both the leading as the trailing edge of the dorsal fin. Nicks are also present on the fluke, on both the dorsal and palmar side, especially on the cranial end therefore entanglement of tailstock is likely. Wider band of approx. 3-4cm present caudally from the pectoral fins running in dorsal-ventral direction along the right flank.

Subcutaneous observations and lesions Subcutaneous fat present, revealing a very well nutritional condition. No macroscopic changes were detected in subcutaneous tissues and the animal's skeleton.

Abdominal cavity Intestine: Mildly filled. Stomachs: Well filled with partly undigested prey and otoliths present. No macroscopic changes were detected in abdominal tissues.

Thorax, head and neck Trachea: Filled with edema. Lungs: Severe alveolar edema, mild parasite infestation possible with associated pneumonia. Pulmonary associated lymph nodes enlarged. Auditory system: Mild bilateral parasite infestation. No other macroscopic changes were detected in other head, neck and thoracic tissues.

Summary of main findings histopathology The histopathological examination revealed that part of 
the lungs had a mild parasite-associated pneumonia, with diffusely a severe alveolar edema and hyperemia. All other major organs showed moderate to severe hyperemia as well, consistent with bycatch. In the cerebrum, locally some perivascular cuffing was observed. Histology of the cerebrum revealed that these lesions were morphologically consistent with a viral infection, although not further characterized.

Conclusion Juvenile male in very good nutritive condition with signs of recent feeding. Mild parasite infestation in lungs, with associated pneumonia, and in the ears. Prominent net marks. Histopathology, in addition, revealed a mild and suspected viral encephalitis.

The pneumonia and encephalitis were diagnosed as mild. As this animal was found in a very good nutritional condition with sign of very recent food intake prior to death, it is doubted whether the additional findings significantly debilitated this individual. However, it cannot be excluded that this harbor porpoise had a reduced health status at the time it got bycaught.

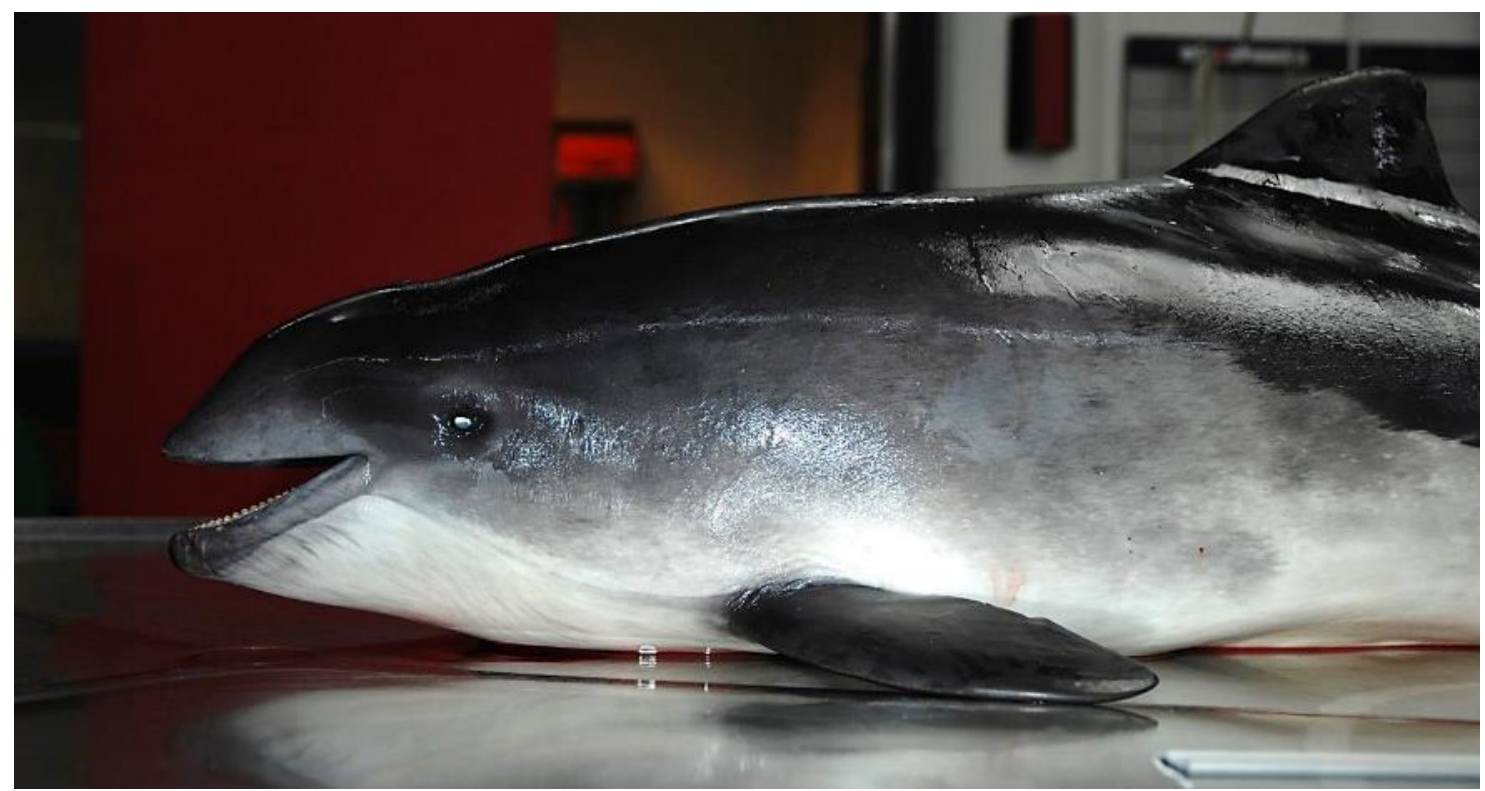

Figure IV.3: Case UT1571 left side head and flank, showing the net mark on the mandible/tip of rostrum as well as the 'open mouth'. Photo Utrecht University

\section{Case UT1006}

Case history This harbor porpoise was found in the fishing nets of one of the REM-project participants on 04-09-2013 and reported by Marije Siemensma. According to the fisherman involved, the animal was found in his gillnet with fluke and tailstock entangled. The fisherman brought the animal into the harbor of Scheveningen, where it was picked up by staff of Utrecht University, department of Pathobiology.

The necropsy was not conducted immediately after recovery of the carcass, because this specimen was used for an experiment to study the appearance and development of so called pseudo hemorrhages after death. The animal was transported to a medical center for a MRI scan and brought to the NIOZ harbor on Texel. The animal was photographed and left for 7 days in the water in a soft net before it was transported back to Utrecht for the necropsy.

When the porpoise was handed over from the fishing vessel, she seemed in good nutritive condition based on MRI scan and in a fresh condition (no signs of decomposition). The porpoise was dead between 7 and 25 hours when handed to UU staff according to the fishermen. The necropsy was performed on 12-09-2013.

Macroscopic findings The specimen was an adult female of $143 \mathrm{~cm}$ total body length and $38,5 \mathrm{~kg}$ total weight. The main macroscopic findings included:

General observations The porpoise was bleeding from the left eye when handed over from the fishermen. No other external wounds were present, except for some mild scavenging around the eyes. After the retrieval of the carcass from the NIOZ harbor, the animal was swollen, with a swollen tongue, 'exploding' eyes and a swollen genital area.

Net marks There were net marks on the rostrum, especially on the maxilla with incisions in upper lip on the left side. Three parallel running net marks in lower lip, left side, approximately $1-3 \mathrm{~cm}$ apart from each other. When porpoise was handed over from the fishermen, two parallel running net mark imprints were present at the smallest part of the tailstock, from top to bottom, with incision in the skin 
dorsally and ventrally of the tailstock. In the evening, when images were taken (approx. 7 hours after first seeing these net marks), the imprints were gone, but the incisions remained. In addition, several small incisions in the edges of the fluke were present, on dorsal and palmar sides bilaterally due to the entanglement of the fluke. All net marks were not visible anymore after retrieval of carcass from NIOZ harbor seven days post mortem due to sloughing of the epidermis.

\section{Case UT1006 follow up}

Subcutaneous observations and lesions The following information is obtained during the necropsy on 12-09-2013 so after retrieval of the carcass from the NIOZ harbor, meaning after 7 days of death. Blubber: Sloughing of skin of fluke, dorsal fin, flippers distal $(50 \%)$, rostral part head, small parts flank and diffuse cracking of epidermis, cranio-caudal direction. Sub cutis: Several pseudohemorrhages occurred post mortem, as proven by the MRI scan. No significant macroscopic changes were detected in other subcutaneous tissues and the animal's skeleton.

Abdominal cavity Intestine and associated lymph nodes: Well filled intestine at proximal part and at distal part with brown/yellow fluid; prominent lymphatics LN. Stomachs: Crab observed in first stomach, together with other content. Other stomach parts seem empty. Genital tract: Pregnant; embryo in the left uterus horn. Embryo size: $3 \times 1.5 \mathrm{~cm}$. Sex of embryo unknown. No significant macroscopic changes were detected in other abdominal tissues.

Thorax, head and neck Lungs: Moderate parasite infestation with associated pneumonia. Parasites in bronchi and blood vessels. $5 \mathrm{~mm}$ of pleural fat present. Esophagus: Stomach content present, indicative of vomiting prior to death. Auditory system: Moderate bilateral parasite infestation. No significant macroscopic changes were detected in other head, neck and thoracic tissues.

Summary of main findings histopathology Only a limited histopathological examination could be conducted due to the advanced state of this carcass. Histopathology confirmed nematode presence in bronchi and vessels of the lungs, with an associated moderate inflammation.

Conclusion Adult pregnant female in good nutritive condition with signs of recent feeding. Certain bycatch. Additional findings: moderate parasite infestation in lungs with associated pneumonia, moderate parasite infestation in ears. Conclusion after necropsy, when animal was in advanced state of decomposition, if animal was not handed over by fishermen: possible bycatch based on macroscopic findings.

Note: due to the state of this carcass at the time of necropsy, more superficial changes in tissues could no longer be observed and the assessment of most internal organs may have been hampered due to the decomposition state of this case.

\section{Case UT1485}

Case history This harbor porpoise was found in the fishing nets of one of the REM-project participants on 20-08-2015 and reported. The fisherman brought the animal into the harbor of Scheveningen, where it was picked up by staff of UU and brought to Utrecht. The necropsy was performed at the faculty of Veterinary Medicine immediately after retrieval.

Macroscopic findings The specimen was a juvenile female of $115 \mathrm{~cm}$ total body length and $25,5 \mathrm{~kg}$ total weight. The main macroscopic findings included:

General observations Some white discolorations were visible on the lips, as well as a papilloma-like lesion on the left side just dorsally from the genital split (Fig. IV.5). The latter lesion was proliferative and $10 \times 3 \mathrm{~cm}$ oval shaped, chronic in appearance. On cut surface, the lesions appeared inflamed and slightly hemorrhagic. Edema protruding from the blowhole.

Net marks Net marks on rostrum, encircling the tip. Also, bilaterally on the pectoral fins, nick and notches damaging the caudal end of the fins are clearly visible (Fig. IV.4). A deeper nick is present on the trailing edge of the dorsal fin. Small nicks are visible on the fluke, on both the dorsal and palmar side.

Subcutaneous observations and lesions No macroscopic changes were detected in subcutaneous tissues and the animal's skeleton.

Abdominal cavity Intestine: Well filled. Stomachs: Well filled with partly undigested prey and otoliths. No abnormalities detected. No macroscopic changes were detected in abdominal tissues.

Thorax, head and neck Lungs: Severe alveolar edema, moderate parasite infestation with associated pneumonia. Auditory system: Severe bilateral parasite infestation. No macroscopic changes 
were detected in other head, neck and thoracic tissues.

Summary of main findings histopathology The histopathological examination revealed mild acute hemorrhage in the skin where net marks were present and hemorrhage in the skeletal muscle. Part of the lungs revealed an extensive necrotic pneumonia, partly as a result of the parasite infestation and alveolar edema. The histology of the proliferative skin lesions is morphologically consistent with herpes virus infection, although not further characterized. All major organs showed moderate to severe hyperemia.

Conclusion Juvenile female in moderate nutritive condition with evidence of recent feeding. Severe lung edema and hyperemia. Prominent net marks. Both macroscopic and histologic findings were consistent with bycatch, although additionally a dermatitis and pneumonia were diagnosed.

Although this animal was able to catch prey and found in a moderate nutritional body condition, the dermatitis and pneumonia could have debilitated this individual, therefore, it can be concluded that this harbor porpoise had a reduced health status at the time it got bycaught.

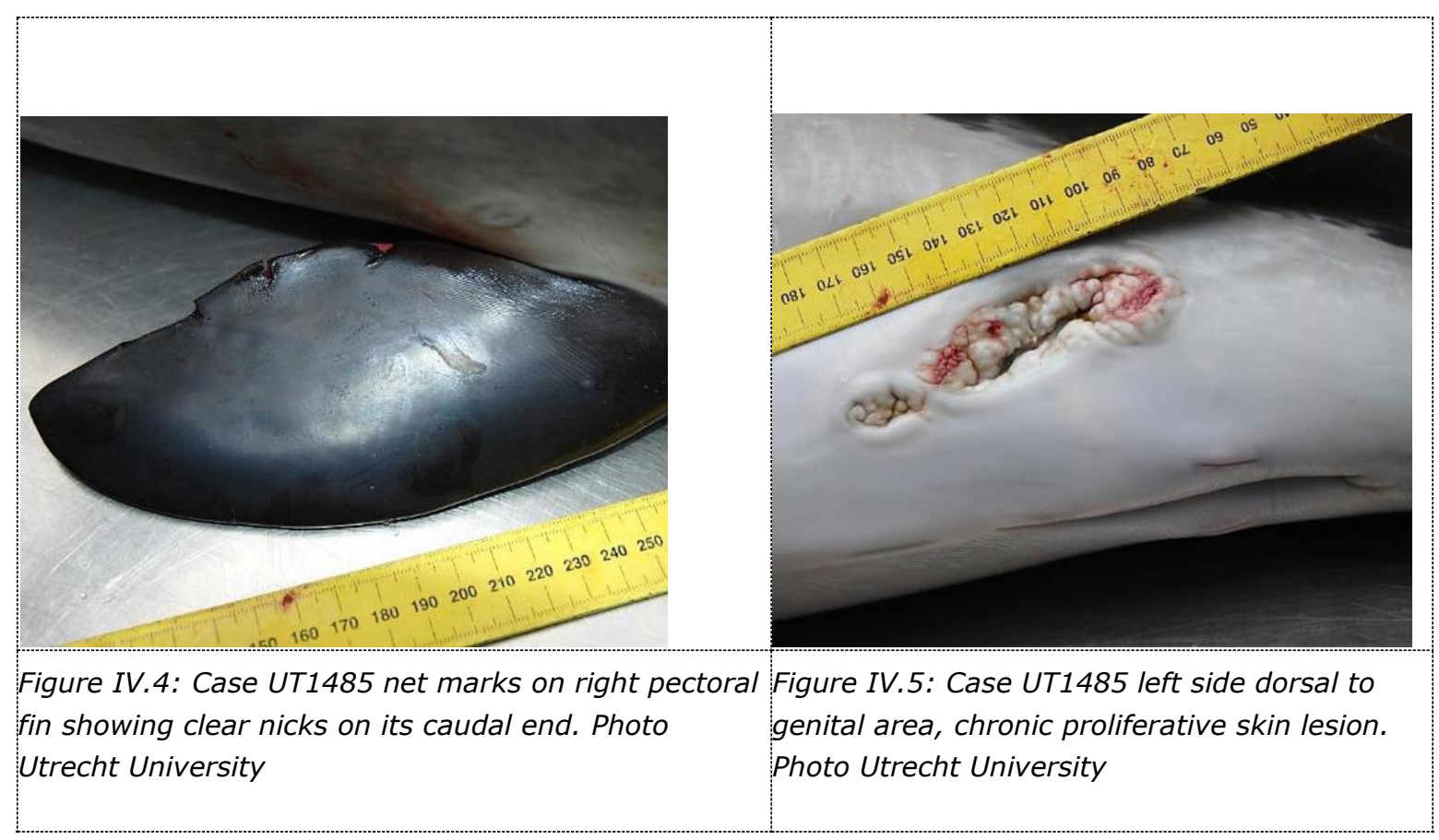

\section{Case UT1417}

Case history This harbor porpoise was found in the fishing nets of one of the REM-project participants on 06-10-2014 and reported in the morning by Marije Siemensma. The fisherman brought the animal into the harbor of Scheveningen, where it was picked up by UU staff and brought to Utrecht. The fishermen reported that the animal was entirely wrapped in the gillnet. The necropsy was performed at the faculty of Veterinary Medicine immediate after retrieval of the carcass.

Macroscopic findings The specimen was a juvenile male of $93,5 \mathrm{~cm}$ total body length and $13,7 \mathrm{~kg}$ total weight. The main macroscopic findings included:

General observations $\pm 70 \%$ of the body surface of the epidermis was irregular due to multifocalcoalescing irregular shaped bulging areas, bilateral. On cut surface the epidermis was thickened here. Edema protruding from the blowhole.

Net marks Around rostrum circular imprints (Fig. IV.6). Two angles are visible, distance of approx. $5 \times 5 \mathrm{~cm}$ square. Around left flipper circular imprint, in the caudal edge cut went through skin $\pm 3 \mathrm{~mm}$ cut, making a little tare with loose flap. Left fluke small cut $\pm 2 \mathrm{~mm}$ deep.

Subcutaneous observations and lesions No macroscopic changes were detected in subcutaneous tissues and the animal's skeleton.

Abdominal cavity Intestine: Segmentally filled at aboral end, enlarged lymphatics in associated mesenteric lymph nodes. Stomachs: Multiple small otoliths present; no abnormalities detected. Liver: Congested. No macroscopic changes were detected in other abdominal tissues. 
Thorax, head and neck Trachea: Completely filled with edema. Lungs: Severe hyperemia and alveolar edema. Esophagus: Focally halfway length, $1 \mathrm{~mm}$ in diameter square ulceration. Also approx. 2 otoliths in esophagus (sign of vomiting prior to death). Teeth: distally not yet erupted.

Summary of main findings histopathology The histopathological examination confirmed the acute and mild hemorrhages in skin where the net imprints were observed. The lungs showed acute multifocal hemorrhage, severe diffuse hyperemia and bacterial presence in airspaces (suspect water aspiration). All major organs showed moderate to severe hyperemia.

Conclusion Juvenile male in poor nutritive condition with evidence of recent feeding. Severe lung edema and hyperemia. Multifocal-coalescing severe epidermal hyperplasia (possible scarring). Focal small esophageal ulceration. Prominent net marks. Both macroscopic and histologic findings were consistent with bycatch.

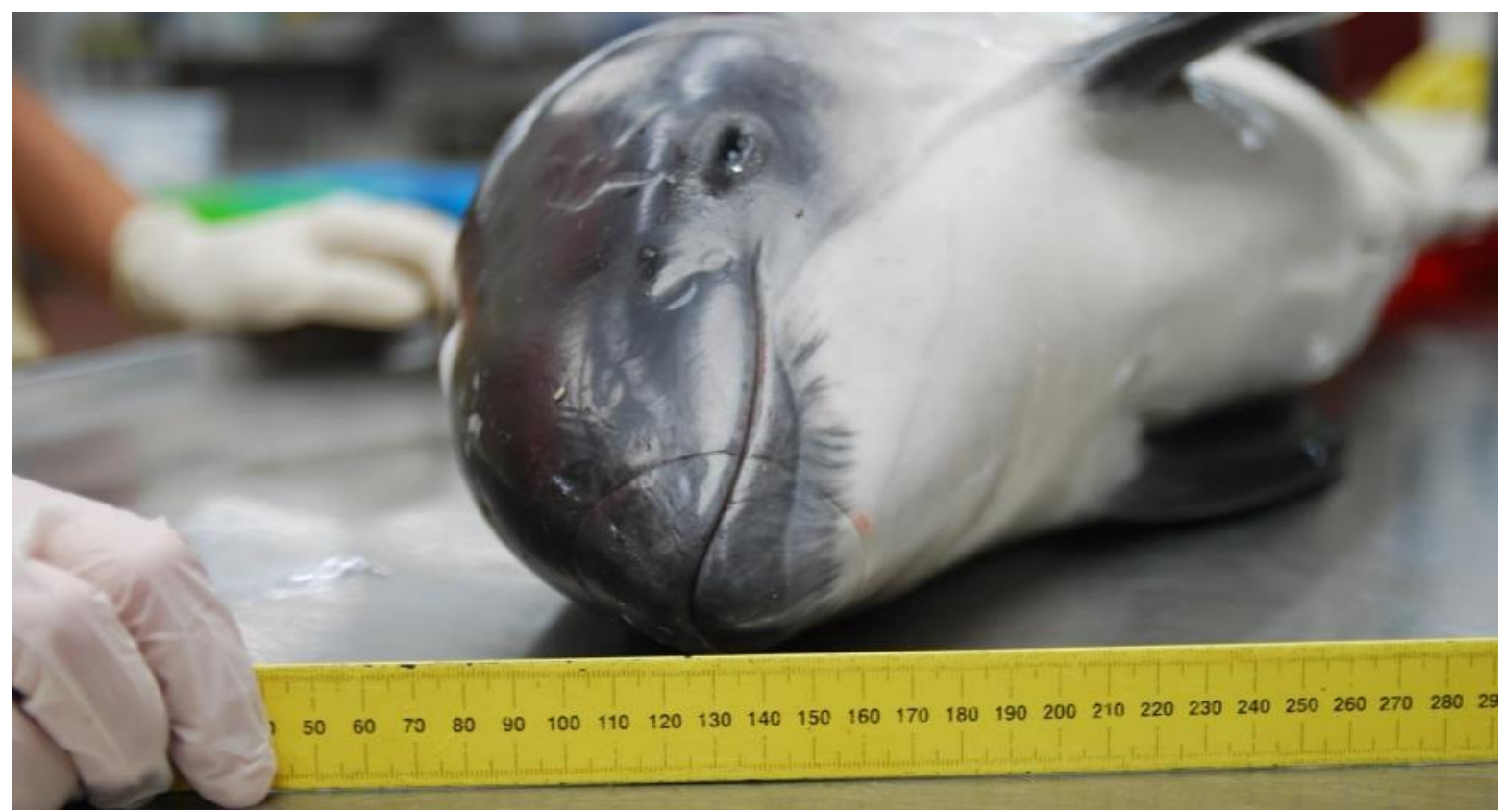

Figure IV.6: Case UT1417 cranial view with net mark encircling the animal's rostrum. Photo Utrecht University

\section{Case UT1317}

Case history This harbor porpoise was found in the fishing nets of one of the REM-project participants on 03-06-2014 and reported in the morning. The fisherman brought the animal into the harbor of Scheveningen, where it was picked up and brought to Utrecht. The fishermen reported that the gillnet was 6-8 times wrapped around the tailstock, therefore entangling the entire fluke. The fisherman estimated that the entanglement happened approximately 4-5 hours prior to landing the nets. A sandeel was reported to hang out of the porpoise's mouth. The necropsy was performed at the faculty of Veterinary Medicine immediate after retrieval of the carcass.

Macroscopic findings The specimen was a juvenile male of $101,5 \mathrm{~cm}$ total body length and $19 \mathrm{~kg}$ total weight. The main macroscopic findings included:

General observations Circular skin lesion palmar side left of $1 \mathrm{~cm}$ in diameter, white discolored. Same lesions on left side dorsal fin: $2 \times 0.5-1 \mathrm{~cm}$ in diameter. No other abnormalities detected.

Net marks Net marks on tailstock and fluke, bilateral (Fig. IV.7). Net mark on rostrum. Two small incisions on both flippers. Right side of the tailstock: towards the dorsal fin, $10 \mathrm{~cm}$ longitudinal cut, irregular surface, not penetrating the epidermis. There was no reaction on cut surface detected. $10 \mathrm{~cm}$ caudally, a similar cut was present but smaller $(5 \mathrm{~cm}$ long), running in the same direction.

Subcutaneous observations and lesions No macroscopic changes were detected in subcutaneous tissues and the animal's skeleton.

Abdominal cavity Intestine: Moderately filled, associated mesenteric lymph nodes enlarged. Stomachs: Well filled with digested and partly digested fish; no abnormalities detected. Spleen: Diffusely, multifocal small $(1 \mathrm{~mm})$ spotted on cut surface. No macroscopic changes were detected in other abdominal tissues. 
Thorax, head and neck Lungs: Mild parasite infestation; severe alveolar edema. Moderate pneumonia with multifocal yellow firmer areas bilateral. Associated pulmonary lymph nodes enlarged. Esophagus: Undigested fish present, 5-10. Auditory system: Severe bilateral parasite infestation. No significant macroscopic changes were detected in other head, neck and thoracic tissues.

Summary of main findings histopathology The histopathological examination revealed a multifocal moderate subacute dermatitis (skin inflammation) with bacterial colonies; a subacute nephritis (kidney inflammation); a multifocal severe parasitic bronchopneumonia (lung inflammation) combined with a multifocal, moderate necrotizing pneumonia; and a mild diffuse parasitic enteritis (intestine inflammation).

Additional inner ear analysis In the right inner ear, a nematode parasite morphologically consistent with Stenurus minor was present at the most basal portion in the cochlea. A severe hemorrhage along the right cochlear spiral, which was likely caused by the S. minor infection, was found possible resulting in impaired hearing in the right ear. These results are included in a manuscript which is currently in preparation.

Conclusion Juvenile male in moderate nutritional body condition with signs of recent feeding. Enlarged lymph nodes on multiple locations. Severe lung edema and moderate pneumonia with a mild parasite infestation. Severe parasite infestation of the ears. Net marks on rostrum and extremities. Histopathology confirmed a subacute dermatitis and nephritis, a mild parasitic enteritis and a severe lung inflammation, partly as a result of the parasite infestation. Impaired hearing in the right ear.

Although this animal was able to catch prey and found in a moderate nutritional body condition, the multiple organ infection as well as the impaired unilateral hearing may have had debilitated effects on this individual, therefore, it can be concluded that this harbor porpoise had a reduced health status at the time it got bycaught.

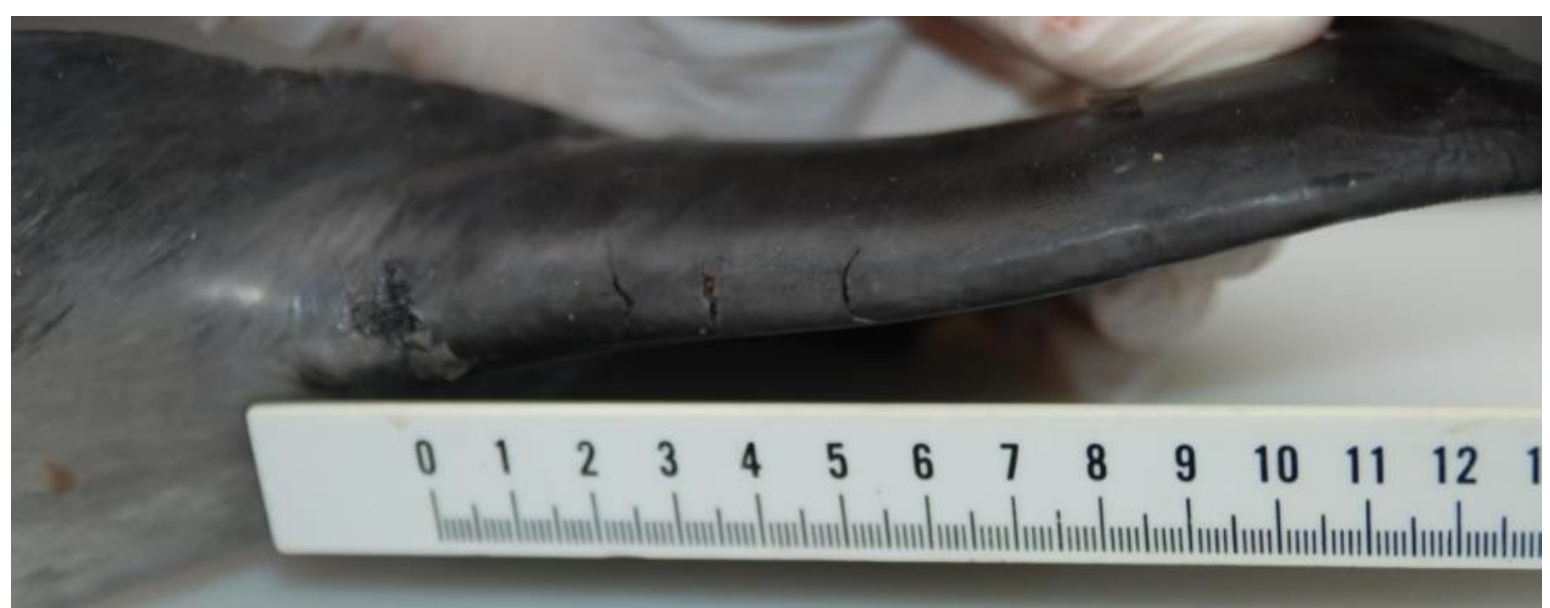

Figure IV.7: Case UT1317 left side tailstock to fluke, revealing several small and superficial net marks. Photo Utrecht University

\section{Case UT1473}

Case history This harbor porpoise was found in the fishing nets of one of the REM-project participants on 12-06-2015 and reported. The fisherman brought the animal into the harbor of Scheveningen, where it was picked up by staff of the 'Dierenambulance Den Haag' and brought to Utrecht. The fisherman reported that the animal was entangled with the tailstock and fluke in the gillnet. The necropsy was performed at the faculty of Veterinary Medicine on 13-06-2017.

Macroscopic findings The specimen was an adult female of $171 \mathrm{~cm}$ total body length and $48 \mathrm{~kg}$ total weight. The main macroscopic findings included:

General observations In general, the animal appeared in a significantly more putrefied state than previous bycaught cases gained through the REM project, e.g. skin started to slough and the animal appeared in an advanced state of decomposition.

Net marks Possible on fluke, tailstock and pectoral fins, however, due to the advanced state of decomposition the damage is less clear and difficult to recognize.

Subcutaneous observations and lesions No significant macroscopic changes were detected in subcutaneous tissues and the animal's skeleton. 
Abdominal cavity Intestine: Empty. Stomachs: Severe nematode infestation in lumen (100's) of $1^{\text {st }}$ compartment as well as a moderate parasite infestation in the wall, presenting $0.5-1 \mathrm{~cm}$ in diameter ulcerations with protruding parasites. The wall of the second compartment contained firm areas ranging to $10 \mathrm{~cm}$ in diameter and completely infested with parasites. Liver: Mild parasite infestation. Genital tract: Multiple corpora scars present on left ovary, indicative of several previous pregnancies. Uterus horns on both sides the same size and color, indicative of resting adult female. No significant macroscopic changes were detected in other abdominal tissues, but state of decomposition could have hampered the assessment.

Thorax, head and neck Lungs: Moderate parasite infestation with associated pneumonia. Esophagus: Tens of nematodes present, as well as some fish eye balls, which are signs of vomiting prior to death. Auditory system: Severe bilateral parasite infestation. No significant macroscopic changes were detected in other head, neck and thoracic tissues, but state of decomposition could have hampered the assessment (e.g. brain could not be examined).

Summary of main findings histopathology No histopathological examination could be conducted due to the advanced state of this carcass.

Conclusion Bycaught adult resting female in very poor nutritive condition with no signs of recent feeding and in advanced state of decomposition. Severe parasite infestation in stomach and ears, moderate in lungs, mild in liver. Moderate associated pneumonia. No histopathological examination could be conducted due to the advanced state of this carcass. Therefore, any other underlying diseases could not been ruled out.

The state of decomposition together with the macroscopic findings strongly suggest that this animal may have been bycaught post mortem and that the cause of death was emaciation due to the severe parasite infestation in multiple organs, with associated inflammation.

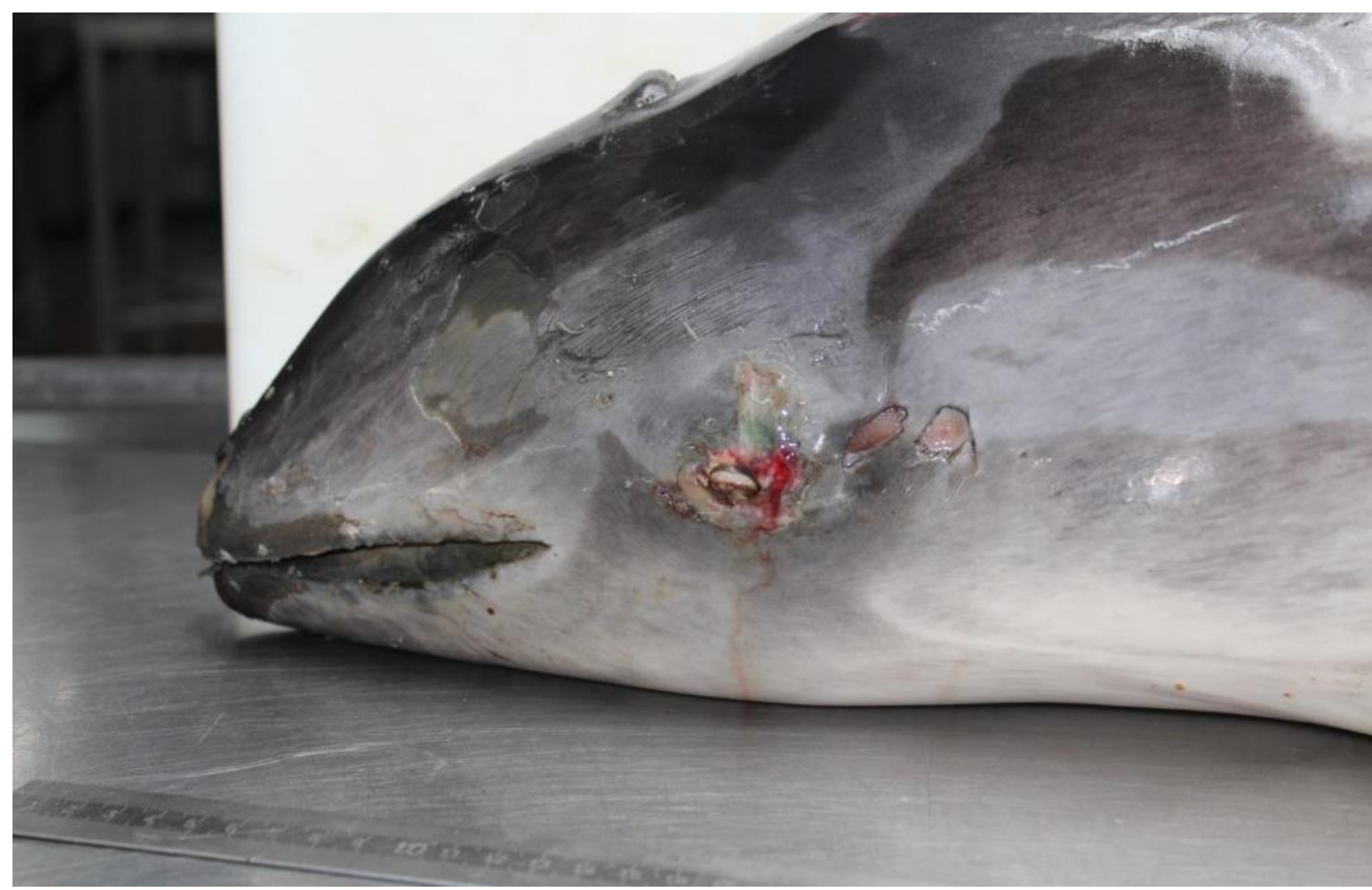

Figure IV.8: Case UT1473 left side head where signs of decomposition are clearly visible, but sloughing skin and severely decomposed eye. Photo Utrecht University 


\section{Annex V - Phases and evaluation of the project}

The project 'Onbedoelde bijvangst in beeld' was commissioned by the Ministry of Agriculture, Nature and Food Quality (LNV, former Ministry of Economic Affairs), under the Beleidsondersteunend Onderzoek (BO), involving both the fishery as well as the nature conservation departments of the Ministry. It was conducted in partnership between Wageningen Marine Research (WMR, former IMARES) and Marine Science \& Communication (MS\&C). WMR lead the installation, data collection and analysis and overall project management. MS\&C acted as an intermediate and liaison between all project partners. The coordination between all project partners was a vital aspect of this project and included regular contact with the participating fishermen by visiting the harbours or contact by phone. Rems Cramer, participating fisherman and representative of the Kenniskring Staandwant visserij (Dutch Fisheries Expert Group on gillnet fisheries) acted as spokesman for the sector and in particular the participants. The transport and pathological research of landed bycaught porpoises was done with the Faculty of Veterinary Medicine, University of Utrecht, Department of Pathobiology.

\section{Project phases}

The project was divided into four phases: project initiation (phase 1); installation of Remote Electronic Monitoring (REM) systems (phase 2); data collection (phase 3) and data analysis (phase 4). The project met several hurdles in phase 1 and phase 2, including a general caution within the fleet to participate as well as considerable technical problems during the installation of the REM systems. Another issue was that during the project additional permits that were issued to pulse fisheries to fish for sole resulted in a short supply of sole quota for most of the participating fishermen. After consultation with the Ministry of Economic Affairs (EZ), the Kenniskring Staandwant visserij, the NL Vissersbond and VisNed the participating fishermen applied successfully at the ministry for a so-called science quota for sole.

\section{Technical challenges}

During the project the installation of the REM systems on board of the vessels met several hurdles. As the participating vessels were relatively small compared to larger trawler vessels the installation company underestimated the technical needs such as sufficient power supply, battery capacity, and sufficient internal space to install the hardware. It is recommended to work closely with the boat owners (in most cases the fisherman) and to realize that working with a small-scale fisheries fleet a case by case approach regarding the installation is recommended. In this particular project technical assistance close to the participating harbours, as recommended by the fishermen, would have been an advantage in order to give technical assistance when needed.

\section{Participants agreement}

A kick-off meeting was held to inform the participants and to address questions. Throughout the project at regular interval the project team visited the fishermen at the harbour or contacted them by phone. All participants signed an agreement for participation as set up to clarify what was expected from both the participating fishermen as well as the other project partners and under which conditions the project was carried out. Fishermen where voluntarily participating and could withdraw from the project at any time. The project team and members of the data analysis team all signed a confidentiality agreement. All participants received a written authorisation and CITES-permit to keep dead bycaught porpoises on-board to be able to land these. A laminated hand out was offered to the fishermen with practical information about the project such as which documents they needed on board, information what to do in case of bycatch, how to change hard disks, clean camera's and contact details of the project team were provided. A member of the project team was available by phone throughout the project, basically $24 / 7$ in case the fishermen had to report a bycatch. 


\section{Bycatch protocol}

In case of bycatch of a death harbour porpoise, fishermen were instructed to: (1) get the animal on board if possible; (2) attach a numbered label with a tie-wrap on the tail root, (3) make a picture of the (a) animal in the net, (b) the entire animal including label, (c) a close-up from of the head and (d) a close-up from the tail. (4) Finally, fishermen where required to report bycatch to a member of the project team and either land the animal in the harbour, or put the animal overboard. In case of landing, the project team arranged discrete take over and transport in and from the harbour to Utrecht University for pathological investigation. Fishermen became informed about the pathological results if they asked for that.

\section{Evaluation meeting December 2016}

In December 2016 an evaluation meeting (Evaluatiebijeenkomst "Onbedoelde bijvangst in beeld") of the project facilitated by Wageningen Economic Research (Former LEI) was held. The results showed that after the initial challenges, the last years of the project were running smoothly with a successful cooperation between all project partners. The project started in a situation where fishermen where accused of deliberately mutilating harbour porpoises. There was mistrust from both industry towards the research institute and the government and vice versa. However, throughout the project all project partners involved gained mutual respect and understanding, creating opportunities for future cooperation between partners involved. The report (in Dutch) can be found at:

http://library.wur.nl/WebQuery/groenekennis/2197992 


\section{Annex VI - Non-Dutch gillnet effort in Dutch waters}

As described in this report it has been a challenge to collect European fishing effort for all nations. One source of European fishing data is the Scientific, Technical and Economic Committee for Fisheries (STECF), which is part of the Joint Research Centre of the European Commission. Data available here consists of effort described as landings in tons as well as fishing hours per ICES quadrants. One should note that the data has limitations due to inconsistencies in data entry.

For more information please visit: https://stecf.jrc.ec.europa.eu/about-stecf

The following maps are based on the data available at this link:

https://stecf.jrc.ec.europa.eu/dd/effort/graphs-quarter

The following filters were used for data selection:

annex: IIA; regulated area: all; ICES rectangle: all; vessel length: all; regulated gear: GN/GT;

specon: NONE; country: all countries but NL/NL; year: 2013, 2014, 2015, 2016; effort: hours fished

Note that the legend for effort (hours fished) varies between figures.

\section{GN FISHING GEAR}

\section{3 - GN}

NON-DUTCH

\section{DUTCH}

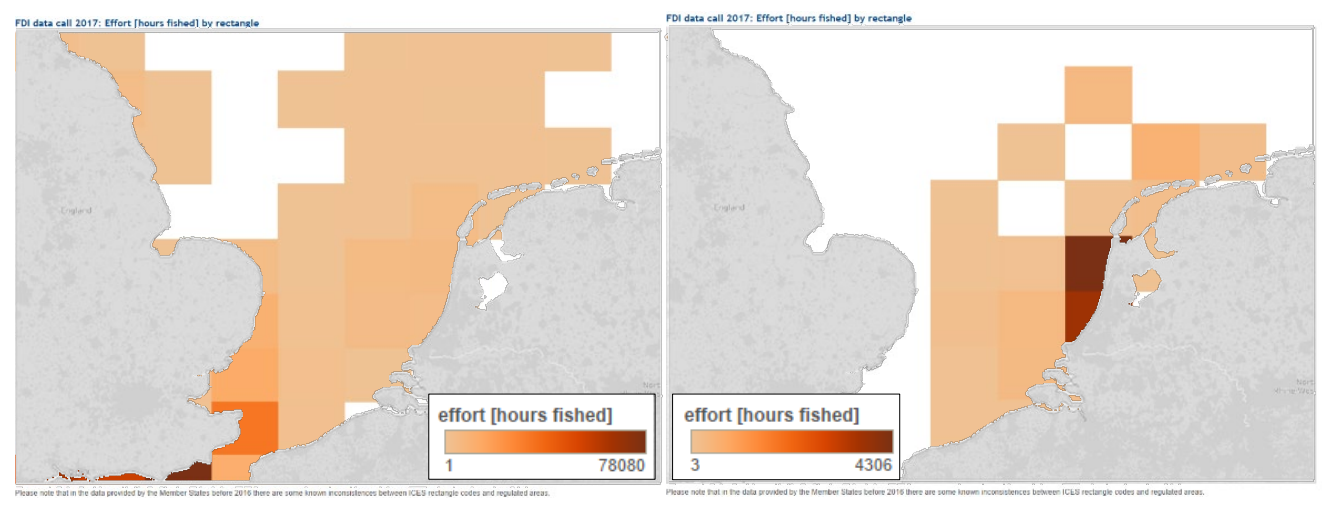

\section{4 - GN}

NON-DUTCH

DUTCH

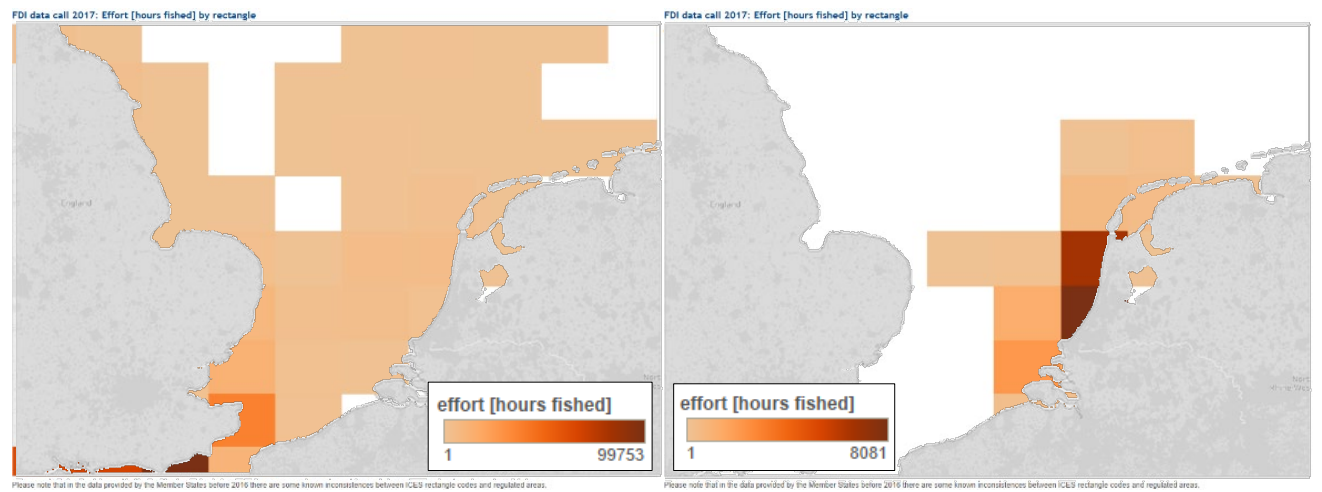


2015 - GN

NON-DUTCH

DUTCH
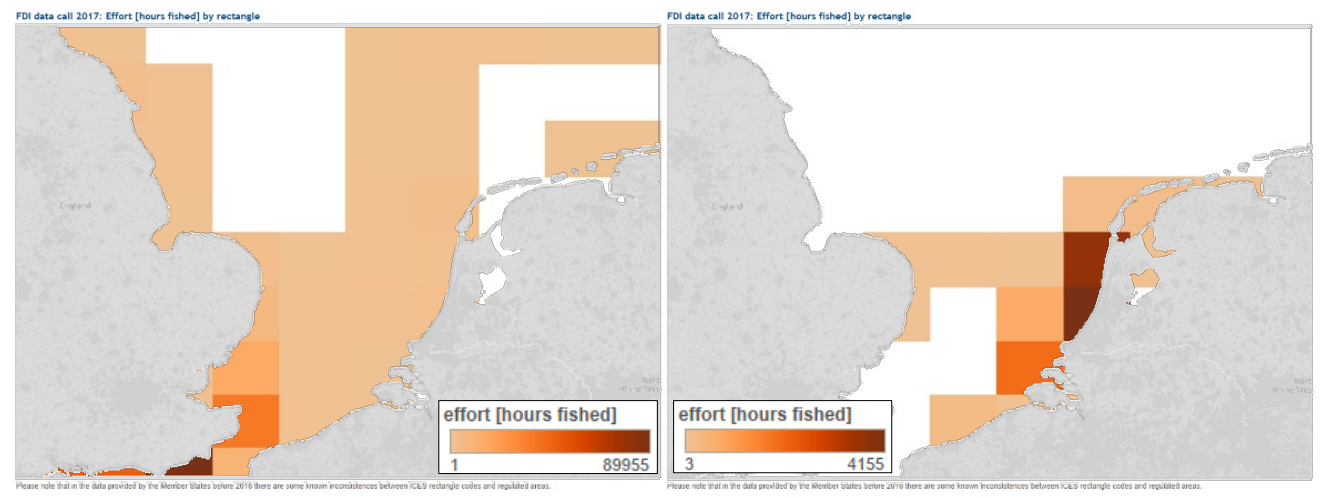

2016 - GN

NON-DUTCH

DUTCH
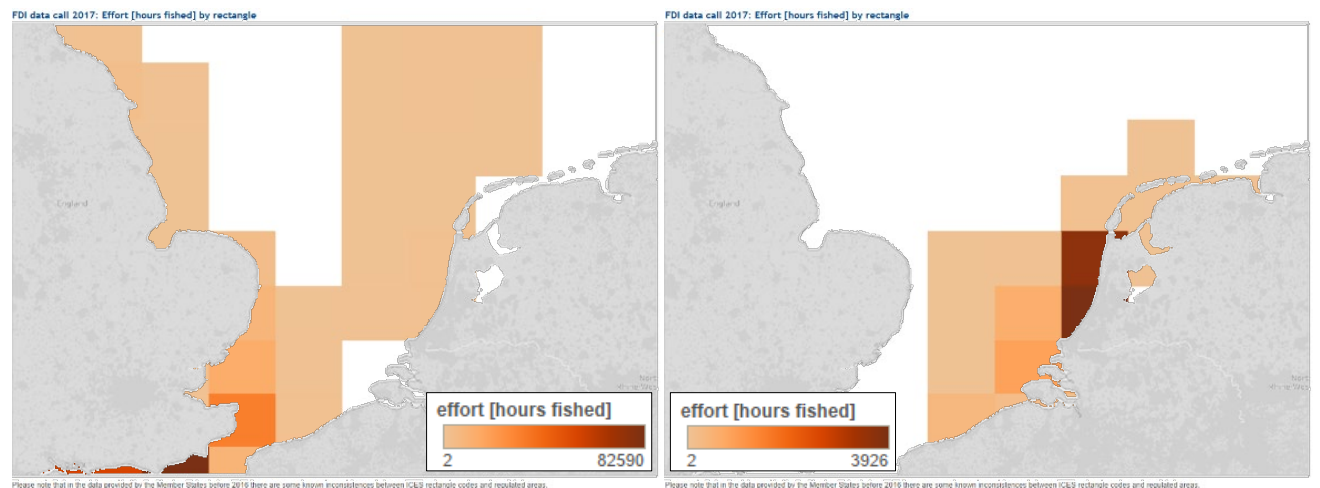


\section{GT FISHING GEAR}

2013 - GT

NON-DUTCH

DUTCH
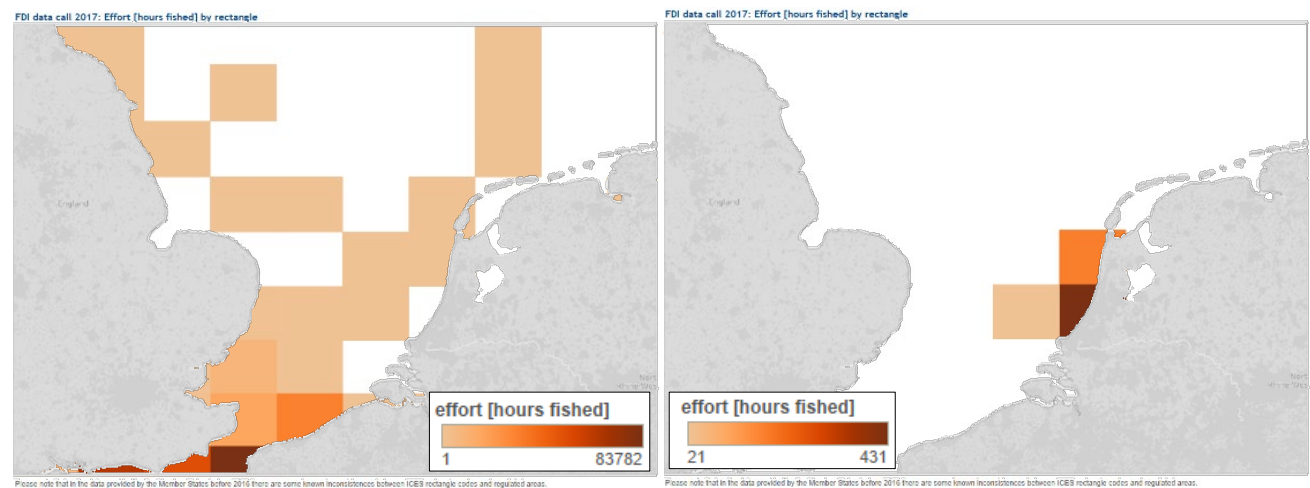

2014 - GT

NON-DUTCH

DUTCH
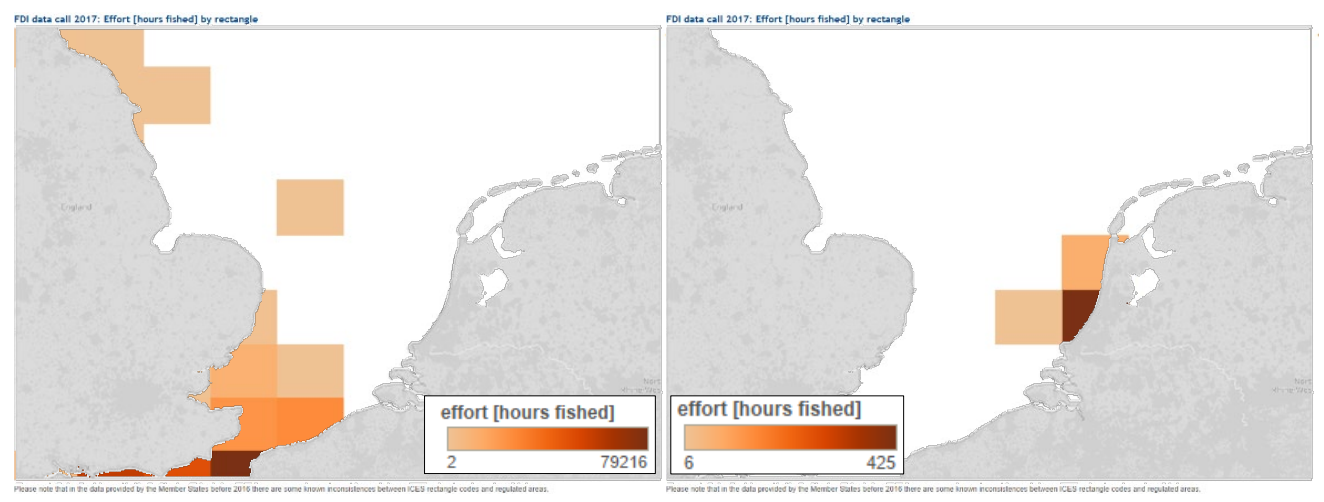

2015 - GT

NON-DUTCH

DUTCH
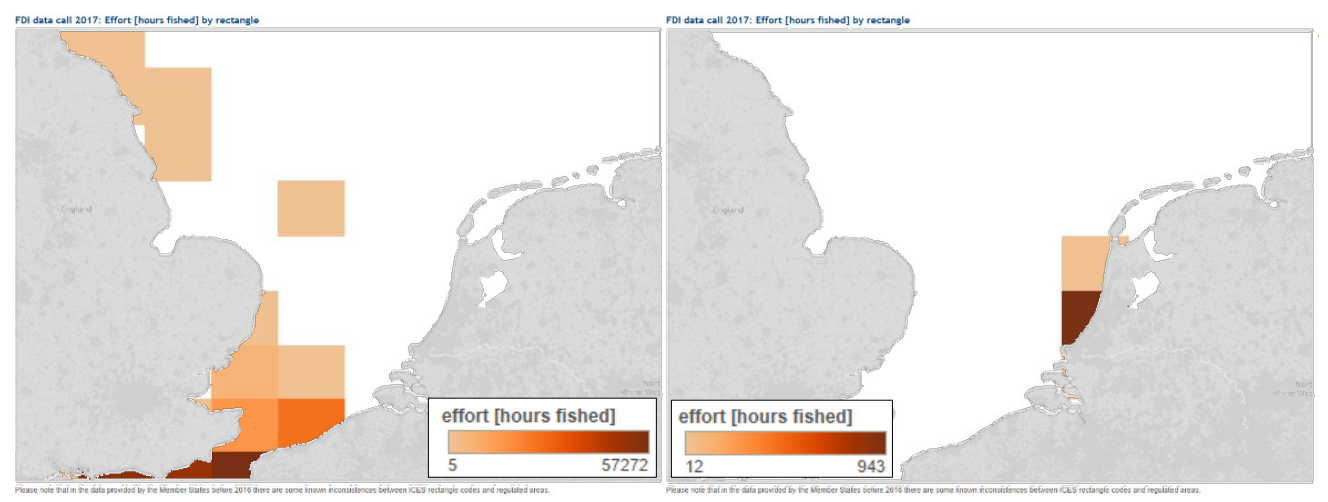
Wageningen Marine Research

T +31(0)317480900

E: marine-research@wur.nl

www.wur.eu/marine-research

Visitors' address

- Ankerpark 271781 AG Den Helder

- Korringaweg 7, 4401 NT Yerseke

- Haringkade 1, 1976 CP IJmuiden
With knowledge, independent scientific research and advice, Wageningen Marine Research substantially contributes to more sustainable and more careful management, use and protection of natural riches in marine, coastal and freshwater areas.
Wageningen Marine Research is part of Wageningen University \& Research. Wageningen University \& Research is the collaboration between Wageningen University and the Wageningen Research Foundation and its mission is: 'To explore the potential for improving the quality of life' 